\title{
Advanced Palladium Membrane Scale-up for Hydrogen Separation
}

Final Report

Project Period: $\quad 1$ October 2010 to 31 October 2012

Reporting Period: 1 October 2010 to 31 October 2012

Date of Report: $\quad 31$ January 2013

Award Number: $\quad$ DE-FE0004967

Principle Sean C. Emerson

Investigator:

Authors: $\quad$ Sean C. Emerson, Neal J. Magdefrau, Ying She, \& Catherine Thibaud-Erkey

Submitting United Technologies Research Center

Organization: $\quad 411$ Silver Lane

East Hartford, CT 06108

Team Members: $\quad$ Power \& Energy, Inc.

106 Railroad Drive

Ivyland, PA 18974-1449

University of North Dakota - Energy \& Environmental Research Center 15 North 23rd Street

Grand Forks, ND 58202-9018

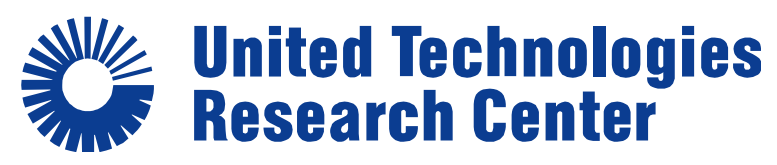


This report was prepared as an account of work sponsored by an agency of the United States Government. Neither the United States Government nor any agency thereof, nor any of their employees, makes any warranty, express or implied, or assumes any legal liability or responsibility for the accuracy, completeness, or usefulness of any information, apparatus, product, or process disclosed, or represents that its use would not infringe privately owned rights. Reference herein to any specific commercial product, process, or service by trade name, trademark, manufacturer, or otherwise does not necessarily constitute or imply its endorsement, recommendation, or favoring by the United States Government or any agency thereof. The views and opinions of the authors expressed herein do not necessarily state or reflect those of the United States Government or any agency thereof. 


\section{Contents}

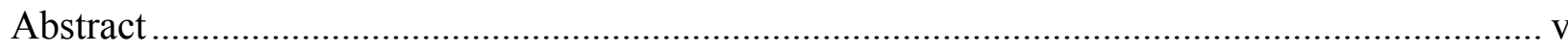

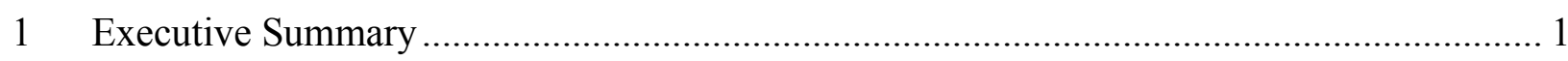

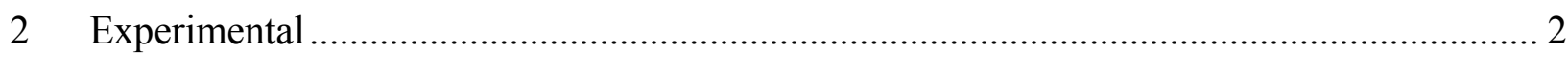

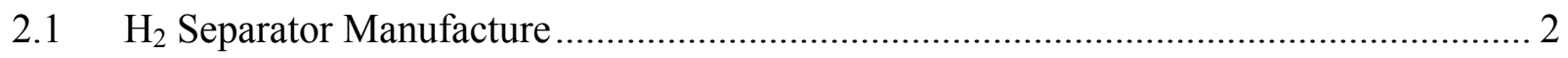

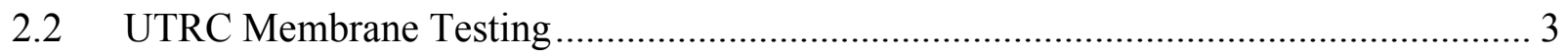

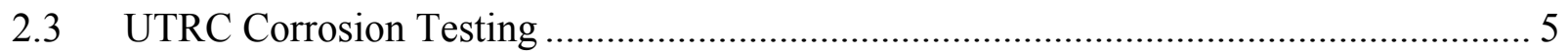

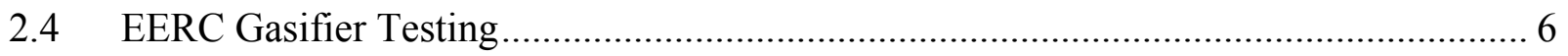

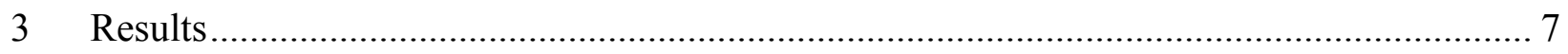

3.1 Impact of Syngas Species and $\mathrm{H}_{2} \mathrm{~S}$ on $\mathrm{H}_{2}$ Permeation ............................................ 7

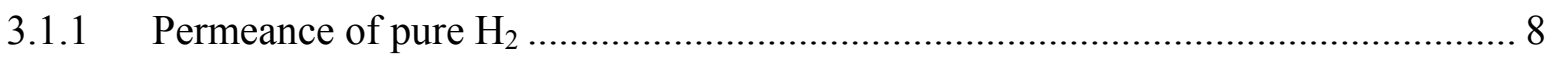

3.1.2 $\mathrm{H}_{2}$ Permeance of $\mathrm{H}_{2}$ gas mixtures ............................................................. 10

3.1.3 $\mathrm{H}_{2}$ Permeance of $\mathrm{H}_{2}$ gas mixtures with $\mathrm{H}_{2} \mathrm{~S}$............................................... 13

3.2 Performance of Surface Modified Membranes versus Baseline ................................ 16

3.3 Effect of Syngas Species and $\mathrm{H}_{2} \mathrm{~S}$ on Membrane Durability .................................... 17

3.3.1 Separator 5290 Durability Testing (Mechanical Tube Failure) ........................... 17

3.3.2 Separator 5313 Durability Testing (Sulfidation Failure) ................................... 20

3.3.3 Burst Testing of Separator Tubes ..................................................................... 22

3.3.4 Irreversible Sulfidation of Pd-Cu Membranes (Modeling \& Characterization) ..... 23

3.3.5 Study of Impact of $\mathrm{H}_{2} \mathrm{~S}$ on Irreversible Sulfidation......................................... 27

3.3.6 Separator 5312 Durability Study to Validate Model and DOE Targets ............... 30

3.4 Pilot Scale $\left(2 \mathrm{lb} /\right.$ day $\left.\mathrm{H}_{2}\right)$ Gasifier Testing .......................................................... 32

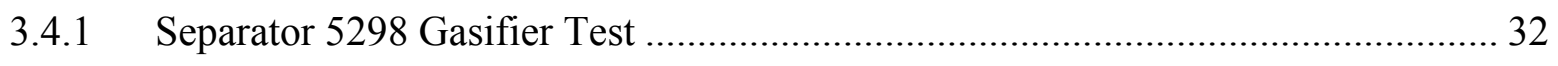

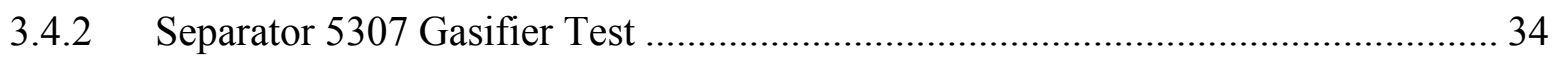

3.4.3 Separator 5307 Post-Gasifier Laboratory Testing .......................................... 34

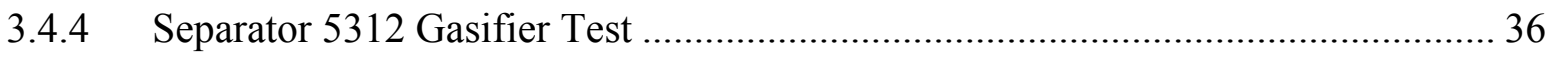

3.4.5 Separator 5312 Post-Gasifier Laboratory Testing (Air Regeneration) .................. 38

3.4.6 Dual Gasifier Test of Separators 5307 \& 5312 ................................................ 39

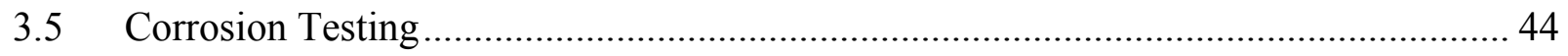

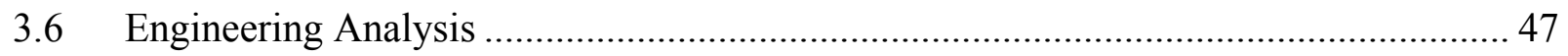

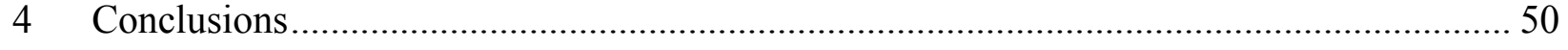

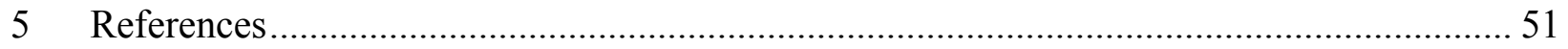




\section{List of Figures}

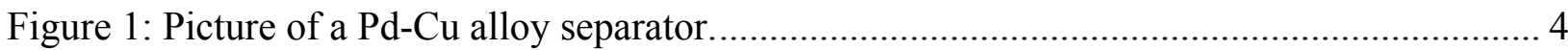

Figure 2: Schematic diagram of the experimental setup.......................................................... 4

Figure 3: Arrhenius plot of pure $\mathrm{H}_{2}$ through a Pd-Cu alloy separator........................................... 9

Figure 4: $\mathrm{H}_{2}$ flux versus $\mathrm{H}_{2}$ square root driving force for different gas mixtures at $400{ }^{\circ} \mathrm{C} \ldots \ldots . .10$

Figure 5: $\mathrm{H}_{2}$ flux versus $\mathrm{H}_{2}$ square root driving force for different gas mixtures at $450{ }^{\circ} \mathrm{C} \ldots \ldots . .12$

Figure 6: $\mathrm{H}_{2}$ flux versus $\mathrm{H}_{2}$ square root driving force for different gas mixtures at $500{ }^{\circ} \mathrm{C}$........ 12

Figure 7: Arrhenius plot of $\mathrm{H}_{2}$ permeation from $\mathrm{H}_{2}$ mixtures through a pilot-scale separator..... 13

Figure 8: $\mathrm{H}_{2}$ flux versus $\mathrm{H}_{2}$ square root driving force for different gas mixtures at $400{ }^{\circ} \mathrm{C}$ with $\mathrm{H}_{2} \mathrm{~S}$ concentrations between $5 \mathrm{ppmv}$ and $39 \mathrm{ppmv}$........................................ 14

Figure 9: $\mathrm{H}_{2}$ flux versus $\mathrm{H}_{2}$ square root driving force for different gas mixtures at $450{ }^{\circ} \mathrm{C}$ with $\mathrm{H}_{2} \mathrm{~S}$ concentrations between $5 \mathrm{ppmv}$ and $39 \mathrm{ppmv}$....................................... 14

Figure 10: $\mathrm{H}_{2}$ flux versus $\mathrm{H}_{2}$ square root driving force for different gas mixtures at $500{ }^{\circ} \mathrm{C}$ with $\mathrm{H}_{2} \mathrm{~S}$ concentrations between $5 \mathrm{ppmv}$ and $39 \mathrm{ppmv}$....................................... 15

Figure 11: $\mathrm{H}_{2}$ permeability durability with and without presence of $\mathrm{H}_{2} \mathrm{~S}$ at different temperatures.................................................................................................. 16

Figure 12: Arrhenius plot of the pure hydrogen permeability versus temperature for the Pd$\mathrm{Cu}$ separators tested through September 2011. Shown are the best curve fits and $95 \%$ confidence limits for the enhanced (coated) $\mathrm{Pd}-\mathrm{Cu}$ laboratory-scale separators, enhanced Pd-Cu pilot-scale separators, and the uncoated Pd-Cu pilotscale separators

Figure 13: Performance and durability testing of laboratory-scale separator 5290..................... 18

Figure 14: Plan view (A) and cross-section (B) SEM images of the membrane leak found in separator 5290. EBSD inverse pole figure (C) shows that the leak occurred at a grain boundary.

Figure 15: Cross-section EDS analysis of the ID of the membrane tube sectioned at the inlet, middle and outlet of the separator shows no evidence of sulfur attack on separator 5290. The sulfur K- $\alpha$ peak would sit at $2.31 \mathrm{keV}$ (see arrows) if present in the

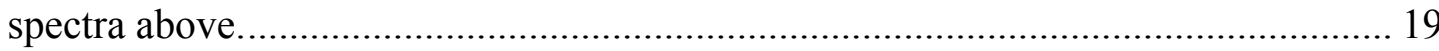

Figure 16: Performance and durability testing of laboratory-scale separator 5313 ..................... 20

Figure 17: A backscattered electron image showing one of the leak sites on separator 5313..... 21

Figure 18: EDS analysis of inlet, middle and outlet tubes from separator 5313 show no sulfur attack on the inlet portion of the separator. Heavy sulfur attack is observed at the outlet end of the membrane as a continuous $\mathrm{Pd}_{4} \mathrm{~S}$ phase.......................................... 22

Figure 19: Comparison of tube burst pressure versus temperature for separators 5290, 5298,

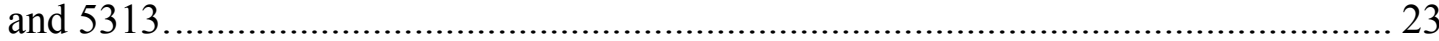

Figure 20: Thermodynamic limit for $\mathrm{Pd}_{4} \mathrm{~S}$ formation as a function of temperature for a $\mathrm{Pd}_{0.7} \mathrm{Cu}_{0.3}$ alloy [15].

Figure 21: Backscattered electron images taken along the length of Separator 5313. $\mathrm{Pd}_{4} \mathrm{~S}$ formation appears to begin at $x / L=0.36$. At $x / L$ greater than 0.5 a continuous $\mathrm{Pd}_{4} \mathrm{~S}$ phase was present on the ID of the membrane tube. 25

Figure 22: UTRC model simulations of separators 5313 and 5290 at $500{ }^{\circ} \mathrm{C}$ to compare the impact of $\mathrm{H}_{2}$ recovery on sulfur concentration in the membrane tubes.

Figure 23: Maximum allowable sulfur level in feed gas at $500{ }^{\circ} \mathrm{C}$ based on separator 5290 resistance to sulfidation as a function of $\mathrm{H}_{2}$ feed concentration and $\mathrm{H}_{2}$ recovery..... 26 
Figure 24: Flow schematic for membrane coupon sulfur exposure testing.

Figure 25: Iyoha et al. [15] thermodynamic equilibrium curve for $\mathrm{Pd}_{4} \mathrm{~S}$ formation and subscale test conditions and results.

Figure 26: Digital photographs showing the specific pattern related to sulfur attack. Coupons 4-31 and 4-85 were not subject to sulfur attack whereas 3-121 shows indications of sulfidation.

Figure 27: Digital microscope images of coupon 3-102, evaluated at $525^{\circ} \mathrm{C}$ and $\mathrm{yH}_{2} \mathrm{~S}_{\mathrm{yH}}=3 \times 10^{-4}$ for 120 hours, exhibiting an atypical ring circle pattern of sulfidation.

Figure 28: $\mathrm{H}_{2}$ permeate flow and operating conditions versus time for separator 5312 tested for 4087 hours $(0.47$ years). The regions labeled A and B were gasifier tests conducted at EERC in January and February 2012 for a combined coal syngas exposure time of 189 hours. Point $\mathrm{C}$ at 1326 hours marks the beginning of a durability test demonstrating $>2 \mathrm{lb} \mathrm{day}^{-1} \mathrm{H}_{2}$ at $95 \%$ recovery in the presence of 1.7 ppmv $\mathrm{H}_{2} \mathrm{~S}$. Point $\mathrm{D}$ at 2624 hours marks the beginning of a small leak in the separator, reducing the $\mathrm{H}_{2}$ purity below $99.9999 \%$.

Figure 29: Measured $\mathrm{N}_{2}$ flow rate and calculated ideal $\mathrm{H}_{2} / \mathrm{N}_{2}$ separation factor as a function of time for separator 5312 starting at time 2624 hours.

Figure 30: Data summary of coal gasifier test in August 2011 of pilot-scale separator 5298. The separator was tested with gasifier exhaust for a total of 64 hours. Under the best gasifier operating conditions, $2.06 \pm 0.16 \mathrm{lb}_{\text {day }}{ }^{-1} \mathrm{H}_{2}$ was separated at an operating pressure of 400 psia.

Figure 31: Data summary of coal gasifier test in September 2011 of pilot-scale separator 5307. The separator was tested with gasifier exhaust for a total of 77 hours and separated $2.43 \pm 0.01 \mathrm{lb} \mathrm{day}^{-1} \mathrm{H}_{2}$ at a mean operating pressure and temperature of 498 psia and $511^{\circ} \mathrm{C}$.

Figure 32: Laboratory testing data for separator 5307 before and after September 2011 and February 2012 gasifier test runs at EERC

Figure 33: Data summary of coal gasifier test in January 2012 of pilot-scale separator 5312. The separator was tested with gasifier exhaust for a total of 130 hours and separated an average of $0.48 \pm 0.28 \mathrm{lb}$ day $^{-1} \mathrm{H}_{2}$ at a mean operating pressure and temperature of 401 psia and $507^{\circ} \mathrm{C}$. During the first bottled $\mathrm{H}_{2}$ addition, $>3.02$ $1 \mathrm{~b}$ day $^{-1} \mathrm{H}_{2}$ was separated.

Figure 34: Laboratory testing data for separator 5312 before and after January 2012 and February 2012 gasifier test runs at EERC

Figure 35: Data summary of coal gasifier test in February 2012 of pilot-scale separator 5307. The separator was tested with gasifier exhaust for a total of 58 hours and separated up to $1.84 \pm 0.16 \mathrm{lb}$ day $^{-1} \mathrm{H}_{2}$ at $501{ }^{\circ} \mathrm{C}$ and 457 psia.

Figure 36: Data summary of coal gasifier test in February 2012 of pilot-scale separator 5312. The separator was tested with gasifier exhaust for a total of 59 hours and separated up to $1.77 \pm 0.14 \mathrm{lb} \mathrm{day}^{-1} \mathrm{H}_{2}$ at $500{ }^{\circ} \mathrm{C}$ and 433 psia.

Figure 37: Comparison of data versus model prediction (blue curves) for the coal gasifier test in February 2012 of pilot-scale separator 5307. Real-time first-principles modeling showed that the performance of the separator fluctuated throughout the run; after compensating for pressure, flow rate, temperature, and gas composition variations; dropping as low as $50 \%$. 
Figure 38: Comparison of data versus model prediction (blue curves) for the coal gasifier test in February 2012 of pilot-scale separator 5312. Real-time first-principles modeling showed that the performance of the separator fluctuated throughout the run; after compensating for pressure, flow rate, temperature, and gas composition variations; dropping as low as $40 \%$.

Figure 39: Laboratory corrosion summary of parabolic weight gain versus exposure time for alternative alloys tested at $500{ }^{\circ} \mathrm{C}$ with 272 ppmv $\mathrm{H}_{2} \mathrm{~S}$.

Figure 40: Optical images of alloy coupons after 2000 hours of laboratory exposure. Note that major pitting was observed on SS-316 and SS-309 alloys. The onset of minor pitting was observed on C-276, OC-11 and HR-120 alloys.

Figure 41: Projected oxide scale thickness versus time were calculated using parabolic rate constants measured in laboratory testing up to 2000 hours of exposure.

Figure 42: Proposed $100 \mathrm{lb}_{\text {day }}{ }^{-1} \mathrm{H}_{2}$ separator module assembly (HSMA) for scale-up efforts. Image (A) shows two modules plumbed in parallel, each containing approximately $49 \mathrm{ft}^{2}$ of membrane area. The image in (B) is of a similar unit delivered to the U.S. Navy for Logistic Fuel Processing for a fuel cell demonstration.

Figure 43: Number of HSMAs depicted in Figure 42A versus $\mathrm{H}_{2}$ separation rate at $89 \%$ recovery for a $25 \% \mathrm{H}_{2}$ syngas at $500{ }^{\circ} \mathrm{C}$ and 500 psia.

Figure 44: Prediction of HSMA performance for $100 \mathrm{lb}$ day ${ }^{-1} \mathrm{H}_{2}$ separation at $89 \% \mathrm{H}_{2}$ recovery.....

\section{List of Tables}

Table 1: Technical status for the project as measured against the DOE's technical targets for

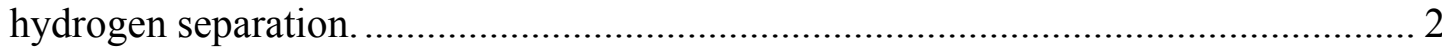

Table 2: Fabrication and delivery status of laboratory-scale and pilot-scale separators. ............... 3

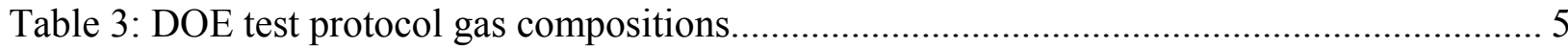

Table 4: Room temperature tensile test data taken from an average of 3 samples for each condition. Note that separator tubes from 5290 showed a $30 \%$ reduction in strength in comparison to all other membrane tubes tested.................................. 20

Table 5: Conditions and results of sulfur exposure coupon testing. ........................................ 28

Table 6: Trace metal concentrations in separator 5312 feed gas during the January 2012 TRDU gasifier run at EERC.

Table 7: Parabolic rate constants and relative corrosion resistance rankings for laboratory and NCCC gasifier corrosion tests.

Table 8: Overall Alloy Selection Table. While SS-309 has the lowest alloy rating parameter, it showed susceptibility to localized pitting. SS-310 appeared to be the best longterm, cost-effective alloy of the eight alloys tested. 


\section{Abstract}

The main objective of this project was to construct, test, and demonstrate a $\mathrm{Pd}-\mathrm{Cu}$ metallic tubular membrane micro-channel separator capable of producing $2 \mathrm{lb} \mathrm{day}^{-1} \mathrm{H}_{2}$ at $\geq 95 \%$ recovery when operating downstream of an actual coal gasifier. A key milestone for the project was to complete a pilot-scale gasifier test by 1 September 2011 and demonstrate the separation of $2 \mathrm{lb}$ day $^{-1} \mathrm{H}_{2}$ to verify progress toward the DOE's goals prior to down-selection for larger-scale $\left(\approx 100 \mathrm{lb} \mathrm{day}^{-1}\right)$ hydrogen separator development.

Three different pilot-scale $\left(\approx 1.5 \mathrm{ft}^{2}\right)$ separators were evaluated downstream of coal gasifiers during four different tests and the key project milestone was achieved in August 2011, ahead of schedule. During three of those tests, all of the separators demonstrated or exceeded the targeted separation rate of $2 \mathrm{lb} \mathrm{day}^{-1} \mathrm{H}_{2}$. The separator design was proved to be leak tight and durable in the presence of gasifier exhaust contaminants at temperatures and pressures up to $500{ }^{\circ} \mathrm{C}$ and 500 psia.

The contaminants in the coal gasifier syngas for the most part had negligible impact on separator performance, with $\mathrm{H}_{2}$ partial pressure being the greatest determinant of membrane performance. Carbon monoxide and low levels of $\mathrm{H}_{2} \mathrm{~S}(<39 \mathrm{ppmv})$ had no effect on $\mathrm{H}_{2}$ permeability, in agreement with laboratory experiments. However, higher levels of $\mathrm{H}_{2} \mathrm{~S}$ ( $>100$ ppmv) were shown to significantly reduce $\mathrm{H}_{2}$ separation performance. The presence of trace metals, including mercury and arsenic, appeared to have no effect based on the experimental data. Subscale $\mathrm{Pd}-\mathrm{Cu}$ coupon tests further quantified the impact of $\mathrm{H}_{2} \mathrm{~S}$ on irreversible sulfide formation in the UTRC separators. Conditions that have a thermodynamic driving force to form coke were found to reduce the performance of the separators, presumably by blockage of effective separation area with carbon deposits. However, it was demonstrated that both in situ and ex situ (laboratory) air regeneration at $450{ }^{\circ} \mathrm{C}$ could restore separator performance by burning out such deposits.

Gasifier testing revealed that high molecular weight hydrocarbons have the potential to retard $\mathrm{H}_{2}$ separation. Unconverted coal tars with carbon numbers greater than 14 have a boiling point such that they can act as a reversible poison to the $\mathrm{Pd}-\mathrm{Cu}$ membranes even at temperatures above $500{ }^{\circ} \mathrm{C}$. The use of real-time, physics-based, performance models revealed the effect of these coal tars. It is believed that this project provided the first evidence for the impact of coal tars on $\mathrm{H}_{2}$ separator performance.

Final down-selection of candidate alloys for non-membrane materials of construction proceeded by evaluating the alloys in both UTRC laboratory tests and testing downstream of an actual gasifier at the National Carbon Capture Center (NCCC). The overall alloy ratings were calculated by multiplying the projected cost of a $100 \mathrm{lb}$ day $^{-1} \mathrm{H}_{2}$ separator outer shell by the projected oxide scale thickness for 5 years of operation. The alloy with the lowest resulting rating parameter was stainless steel 309 (SS-309) followed by stainless steel 310 (SS-310). However, it was noted that approximately half of the alloys showed susceptibility to pitting and localized corrosion. SS-309 was one of the alloys that exhibited heavy localized attack after 2000 hours of laboratory testing. As this localized corrosion can potentially lead to accelerated end of life, it was determined that SS-310 would be the best alloy selection for this application as it does not show signs of localized pitting corrosion. 


\section{Executive Summary}

Advancements in hydrogen $\left(\mathrm{H}_{2}\right)$ membrane separation are critical to allow the development of a viable $\mathrm{H}_{2}$ economy based on coal/biomass processing with $\mathrm{CO}_{2}$ capture. United Technologies Research Center (UTRC), in collaboration with Power+Energy, Inc. (P+E) and the Energy \& Environmental Research Center at the University of North Dakota (EERC), therefore proposed to demonstrate palladium ( $\mathrm{Pd}$ ) based membrane separation of $\mathrm{H}_{2}$ from coal-derived syngas at the pre-engineering/pilot scale.

In Phase I of the project, described in this final report, the objectives were to: (1) Construct, test, and demonstrate a $\mathrm{Pd}-\mathrm{Cu}$ metallic tubular membrane micro-channel separator capable of producing $2 \mathrm{lb} /$ day of $\mathrm{H}_{2}$ at $\geq 95 \%$ recovery when operating downstream of an actual coal gasifier; (2) Quantify the impact of simulated gas composition and temperature on separator performance; (3) Compare the performance and durability of a surface modified, higher $\mathrm{H}_{2}$ flux $\mathrm{Pd}-\mathrm{Cu}$ membrane with the baseline Pd-Cu tubular membrane; (4) Evaluate various materials of construction for the separator structural parts to ensure durability under harsh gasifier conditions; (5) Perform an engineering analysis using National Energy Technology Laboratory (NETL) guidelines of the separator design based on gasifier test performance for the co-production of electric power and clean fuels; and (6) Select a gasification facility partner for Phase III.

Three different pilot-scale $\left(\approx 1.5 \mathrm{ft}^{2}\right)$ separators were evaluated downstream of coal gasifiers during four different tests and the key project milestone was achieved in August 2011, ahead of schedule. During three of those tests, all of the separators demonstrated or exceeded the targeted separation rate of $2 \mathrm{lb} d a y^{-1} \mathrm{H}_{2}$. The separator design was proved to be leak tight and durable in the presence of gasifier exhaust contaminants at temperatures and pressures up to $500{ }^{\circ} \mathrm{C}$ and 500 psia. The details of the gasifier testing results are given in Section 3.4.

The contaminants in the coal gasifier syngas for the most part had negligible impact on separator performance, with $\mathrm{H}_{2}$ partial pressure being the greatest determinant of membrane performance. Carbon monoxide and low levels of $\mathrm{H}_{2} \mathrm{~S}(<39 \mathrm{ppmv})$ had no effect on $\mathrm{H}_{2}$ permeability, in agreement with laboratory experiments. However, higher levels of $\mathrm{H}_{2} \mathrm{~S}$ $\left(>100\right.$ ppmv) were shown to significantly reduce $\mathrm{H}_{2}$ separation performance. The presence of trace metals, including mercury and arsenic, appeared to have no effect based on the experimental data. Separator testing showed that there was no impact of carbon monoxide on $\mathrm{H}_{2}$ permeability at temperatures $\geq 400{ }^{\circ} \mathrm{C}$, even at very high partial pressures. Subscale $\mathrm{Pd}-\mathrm{Cu}$ coupon tests were initiated to further quantify the impact of $\mathrm{H}_{2} \mathrm{~S}$ on irreversible sulfide formation in the UTRC separators. A final 4087 hour separator test showed that under the proper operating conditions, $>2 \mathrm{lb}_{\text {day }}{ }^{-1} \mathrm{H}_{2}$ could be separated at $95 \%$ recovery without total membrane failure.

Conditions that have a thermodynamic driving force to form coke were found to reduce the performance of the separators, presumably by blockage of effective separation area with carbon deposits. However, it was demonstrated that both in situ and ex situ (laboratory) air regeneration at $450{ }^{\circ} \mathrm{C}$ could restore separator performance by burning out such deposits.

Gasifier testing revealed that high molecular weight hydrocarbons have the potential to retard $\mathrm{H}_{2}$ separation. Unconverted coal tars with carbon numbers greater than 14 have a boiling point such that they can act as a reversible poison to the $\mathrm{Pd}-\mathrm{Cu}$ membranes even at temperatures above $500{ }^{\circ} \mathrm{C}$. The use of real-time, physics-based, performance models revealed the effect of these coal tars. It is believed that this project provided the first evidence for the impact of coal tars on $\mathrm{H}_{2}$ separator performance. 
Final down-selection of candidate alloys for non-membrane materials of construction proceeded by evaluating the alloys in both UTRC laboratory tests and testing downstream of an actual gasifier at NCCC. The overall alloy ratings were calculated by multiplying the projected cost of a $100 \mathrm{lb}$ day $^{-1} \mathrm{H}_{2}$ separator outer shell by the projected oxide scale thickness for 5 years of operation. The alloy with the lowest resulting rating parameter was SS-309 followed by SS-310. However, it was noted that approximately half of the alloys showed susceptibility to pitting and localized corrosion. SS-309 was one of the alloys that exhibited heavy localized attack after 2000 hours of laboratory testing. As this localized corrosion can potentially lead to accelerated end of life, it was determined that SS-310 would be the best alloy selection for this application as it does not show signs of localized pitting corrosion.

The project status relative to the DOE's 2015 technical targets for hydrogen separation is given in Table 1. The results for laboratory studies on contaminant effects on $\mathrm{H}_{2}$ flux are described in Section 3.1 and the comparison of conventional versus enhanced $\mathrm{Pd}-\mathrm{Cu}$ membranes is shown in Section 3.2. The efforts to investigate irreversible sulfidation of the membranes and its impact on membrane durability are described in Section 3.3. Details on the gasifier tests, the impact of high levels of $\mathrm{H}_{2} \mathrm{~S}$ and high molecular weight gasifier tars on separator performance during those tests and the air regeneration of membranes are given in Section 3.4. The corrosion study results for non-membrane materials of construction are described in Section 3.5. Finally, the engineering analysis to predict the performance of a larger-scale separator is summarized in Section 3.6. As this project did not proceed to Phase II, no gasification facility partner was formally identified.

Table 1: Technical status for the project as measured against the DOE's technical targets for hydrogen separation.

\begin{tabular}{|l|c|c|c|}
\hline Performance Criteria & Units & DOE 2015 Target & Final Project Status \\
\hline $\mathrm{H}_{2}$ Flux & $\mathrm{ft}^{3} \mathrm{ft}^{-2} \mathrm{~h}^{-1}$ & 300 & $\begin{array}{c}28 \\
\text { (EERC TRDU gasifier test, [1]) }\end{array}$ \\
\hline Temperature & ${ }^{\circ} \mathrm{C}$ & $250-500$ & $250-600$ \\
\hline Sulfur tolerance & $\mathrm{ppmv}$ & $>100$ & $\begin{array}{c}\mathrm{H}_{2} \mathrm{~S} / \mathrm{H}_{2}=7.29 \times 10^{-5} \\
618 \mathrm{~h} \text { at 5-39 ppmv S }(0.008 \text { psia S) }\end{array}$ \\
\hline Cost & $\$ / \mathrm{ft}^{2}$ & $<100$ & $\begin{array}{c}400-500 \\
>24 \mathrm{~h} \text { at 236-963 ppmv S }(0.0104-0.0425 \text { psia S) }\end{array}$ \\
\hline$\Delta \mathrm{P}$ operating capability & $\mathrm{psi}$ & $800-1000$ & 500 \\
\hline CO tolerance & - & Yes & $16 \% \mathrm{CO}$ \\
\hline $\mathrm{H}_{2}$ purity & $\%$ & 99.99 & 99.9999 \\
\hline Stability/Durability & Years & 5 & $4087 \mathrm{~h}(0.47$ years) \\
\hline
\end{tabular}

\section{Experimental}

\section{$2.1 \mathrm{H}_{2}$ Separator Manufacture}

$\mathrm{P}+\mathrm{E}$ manufactured and delivered a total of six laboratory-scale $\left(\approx 0.1 \mathrm{ft}^{2}\right)$ separators as well as six pilot-scale $\left(\approx 1.5 \mathrm{ft}^{2}\right)$ separators. Table 2 shows the delivery dates and basic information on the laboratory-scale separators produced under this contract, including two smaller separators delivered under a previous contract (DE-FC26-07NT43055) [2]. Based on the information from early corrosion tests (see Section 3.5), as well as the availability of alloys in the forms needed for fabrication, it was decided that all separators delivered after approximately mid-2011 would be made out of C-22 and/or C-276. As a result, four of the laboratory-scale separators and all of the 
pilot-scale separators were made using these alloys. Due to manufacturing delays, the first two pilot-scale separators were made with non-surface enhanced $\mathrm{Pd}-\mathrm{Cu}$ alloys. The remaining pilotscale separators were made with the enhanced (coated) Pd-Cu membranes.

Table 2: Fabrication and delivery status of laboratory-scale and pilot-scale separators.

\begin{tabular}{|c|c|c|c|c|}
\hline $\begin{array}{c}\text { Separator } \\
\text { Identification }\end{array}$ & Delivery Date & Material of & Maximum & Permeation area \\
Operating & $/ \mathrm{cm}^{2}\left(\mathrm{ft}^{2}\right)$ \\
\hline
\end{tabular}

\begin{tabular}{|c|c|c|c|c|}
\hline 5265 & 2010 (Previous contract) & SS-316 & $200 \mathrm{psia}$ & $18.20(0.0196)$ \\
\hline 5266 & 2010 (Previous contract) & SS-316 & $200 \mathrm{psia}$ & $18.20(0.0196)$ \\
\hline 5276 & $12 / 23 / 2010$ & SS-316 & $200 \mathrm{psia}$ & $109.2(0.1175)$ \\
\hline 5277 & $12 / 23 / 2010$ & SS-316 & $200 \mathrm{psia}$ & $109.2(0.1175)$ \\
\hline 5290 & $03 / 25 / 2011$ & C-276 (Hastelloy 276) / SS-316 & $200 \mathrm{psia}$ & $109.2(0.1175)$ \\
\hline 5291 & $03 / 25 / 2011$ & C-276 (Hastelloy 276) / SS-316 & $200 \mathrm{psia}$ & $109.2(0.1175)$ \\
\hline 5295 & $07 / 22 / 2011$ & C-276 & $200 \mathrm{psia}$ & $109.2(0.1175)$ \\
\hline 5296 & $07 / 22 / 2011$ & C-276 & $200 \mathrm{psia}$ & $109.2(0.1175)$ \\
\hline 5297 & $05 / 27 / 2011$ & $\begin{array}{c}\text { C-276 plus C-22 } \\
\text { (uncoated Pd-Cu) }\end{array}$ & $400 \mathrm{psia}$ & $1353(1.46)$ \\
\hline 5298 & $05 / 27 / 2011$ & $\begin{array}{c}\text { C-276 plus C-22 } \\
\text { (uncoated Pd-Cu) }\end{array}$ & $400 \mathrm{psia}$ & $1353(1.46)$ \\
\hline 5307 & $07 / 19 / 2011$ & C-276 plus C-22 & $500 \mathrm{psia}$ & $1353(1.46)$ \\
\hline 5312 & $09 / 08 / 2011$ & C-276 plus C-22 & $500 \mathrm{psia}$ & $1353(1.46)$ \\
\hline 5313 & $09 / 08 / 2011$ & C-276 plus C-22 & $500 \mathrm{psia}$ & $1353(1.46)$ \\
\hline 5314 & $09 / 16 / 2011$ & C-276 plus C-22 & $500 \mathrm{psia}$ & $1353(1.46)$ \\
\hline
\end{tabular}

\subsection{UTRC Membrane Testing}

Lab-scale and pilot-scale tubular Pd-Cu separators were fabricated by $\mathrm{P}+\mathrm{E}$ for $\mathrm{H}_{2}$ permeability evaluation. Each separator consisted of several fcc Pd-Cu alloy self-supported membrane tubes with a thickness of about $45.8 \mu \mathrm{m}$ and a $\mathrm{H}_{2}$ permeation area of $109.2 \mathrm{~cm}^{2}$ for the lab-scale separator. The pilot-scale separator had a thickness of about $58.6 \mu \mathrm{m}$ and an area of $1,353 \mathrm{~cm}^{2}$. The separators were constructed and configured using P+E's micro-channel technology such that all external mass transfer resistances were minimized. The separators were produced according to established manufacturing techniques developed by $\mathrm{P}+\mathrm{E}$ for other commercial $\mathrm{H}_{2}$ separators and purifiers. An image of a typical $\mathrm{H}_{2}$ separator is shown in Figure 1. The feed was introduced into the separator through one of the two ports in line on the top of the separator and the other one was used for a thermocouple to control the temperature. The retentate was collected from the top port while the permeate flowed out of the bottom port. 


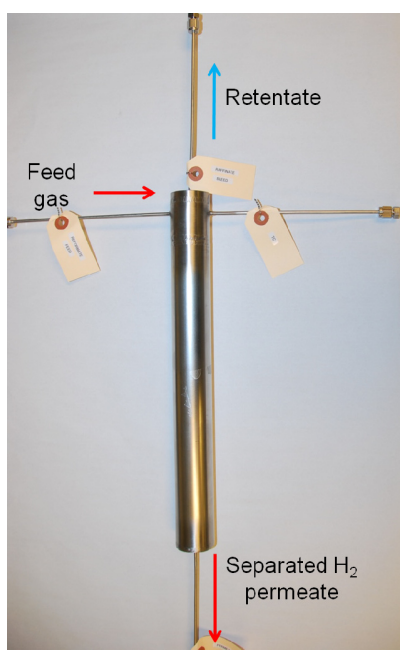

Figure 1: Picture of a Pd-Cu alloy separator.

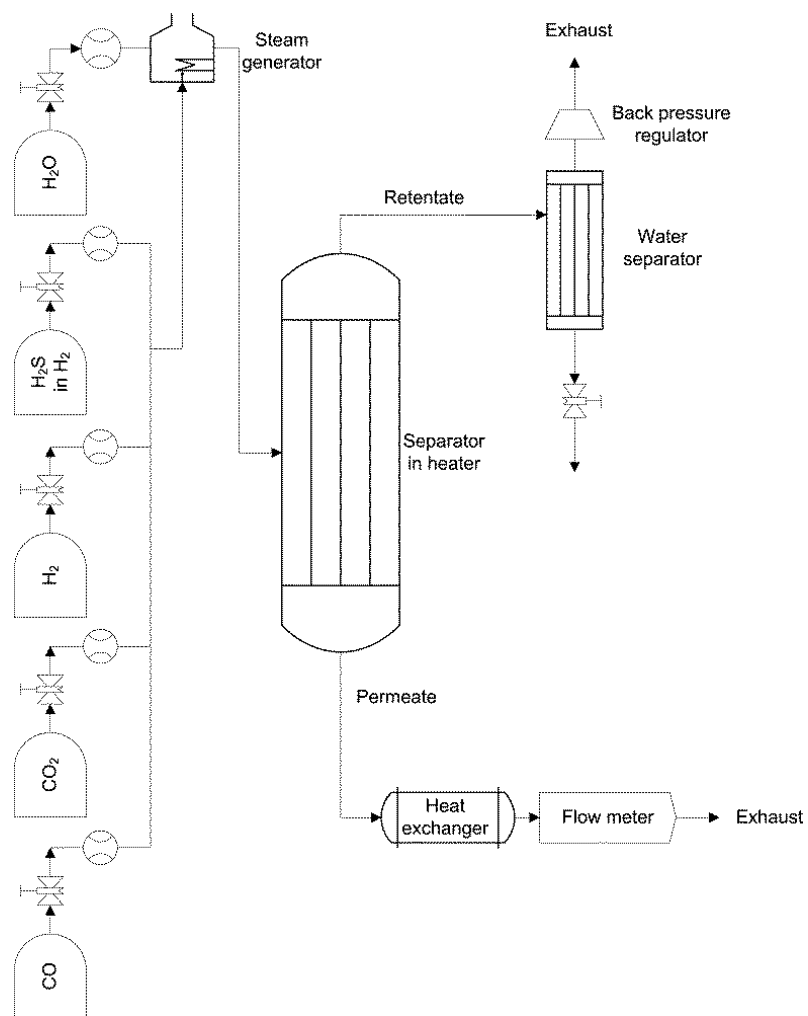

Figure 2: Schematic diagram of the experimental setup.

Figure 2 shows the schematic diagram of the gas permeation testing setup. A simulated syngas was made by mixing $\mathrm{H}_{2}, \mathrm{CO}_{2}, \mathrm{CO}$, and $\mathrm{H}_{2} \mathrm{O}$ vapor with and without addition of $\mathrm{H}_{2} \mathrm{~S}$. $\mathrm{CO}$, $\mathrm{CO}_{2}$, and $\approx 1000$ ppmv $\mathrm{H}_{2} \mathrm{~S}$ in $\mathrm{H}_{2}$ were fed into the system from gas cylinders while $\mathrm{H}_{2}$ and $\mathrm{N}_{2}$ was delivered from house gas supplies. The house $\mathrm{H}_{2}$ was generated by electrolysis of deionized (DI) water through an electrolyzer produced by Proton Energy, Inc. The house $\mathrm{N}_{2}$ was from a liquefied $\mathrm{N}_{2}$ storage tank in the facility and the liquefied $\mathrm{N}_{2}$ was purchased from Praxair. Purity of these gases was greater than $99.998 \%$. DI water was fed into the system through a water meter 
by pressurizing its reservoir in a stainless steel cylinder with the house $\mathrm{N}_{2}$. The meter was made by Bronkhorst High-Tech. All the gas flow rates were controlled by Brooks mass flow controllers. The separator was heated by a ceramic heater. A thermocouple was inserted inside the separator to control the temperature. To monitor the temperatures along the separator length, three additional thermocouples were attached to the top, middle, and bottom of the separator. A heating tape was used to wrap the lower part of the separator to provide additional heat for better isothermal control. Pressure control was achieved by using a Tescom back pressure regulator. $\mathrm{H}_{2}$ permeation flow rate was measured by an Alicat flow meter from Alicat Scientific, Inc.

The test rig was controlled by a LabView control program written by UTRC. Testing parameters for gas flow rates, temperatures and pressures were set and controlled through the program. Data acquisition was also achieved by the control program. The LabView program had two control modes (auto and manual). The auto mode allowed one to load a test plan with a series of steps that consisted of the testing conditions for each step (flow rates, temperatures, pressures, and duration) and the control program executed the test plan sequentially. The manual mode gave one an option to input and modify the test parameters during the testing and kept executing these parameters until they were manually adjusted. This program was very flexible and robust, allowing the test to be operated unattended 24 hours a day.

The Pd-Cu alloy membranes were tested for $\mathrm{H}_{2}$ separation using pure $\mathrm{H}_{2}$ as well as a variety of binary $\mathrm{H}_{2}$ gas mixtures $\left(\mathrm{H}_{2}-\mathrm{N}_{2} ; \mathrm{H}_{2}-\mathrm{CO} ; \mathrm{H}_{2}-\mathrm{CO}_{2} ; \mathrm{H}_{2}-\mathrm{H}_{2} \mathrm{O}\right)$ and simulated syngas $\left(\mathrm{H}_{2}-\mathrm{CO}-\mathrm{CO}_{2}-\right.$ $\mathrm{H}_{2} \mathrm{O}$ ) with and without the addition of $\mathrm{H}_{2} \mathrm{~S}$ at temperatures between $400{ }^{\circ} \mathrm{C}$ and $500{ }^{\circ} \mathrm{C}$ under pressures between 2.03 bar and 13.79 bar to understand the impact of each major non-hydrogen species and $\mathrm{H}_{2} \mathrm{~S}$ in the mixtures on the $\mathrm{H}_{2}$ permeation. $\mathrm{H}_{2} \mathrm{~S}$ concentration in the simulated syngas was controlled by blending about 1000 ppmv $\mathrm{H}_{2} \mathrm{~S}$ in pure $\mathrm{H}_{2}$ with the other gases. The $\mathrm{H}_{2} \mathrm{~S}$ concentration in the dry feed was checked by Dräger tube analysis.

$\mathrm{N}_{2}$ leak checks were conducted at 13.79 bar for most cases, either at room temperature or at testing temperatures, with a $0.01 \mathrm{~mL}$ resolution bubble meter. A Pd-Cu separator was defined as being leak free when no $\mathrm{N}_{2}$ flow was observed under 13.79 bar for five minutes.

In addition, a DOE test protocol was used to evaluate the $\mathrm{Pd}-\mathrm{Cu}$ separator performance. The DOE test protocol is listed Table 3 . This protocol was primarily designed by the DOE for syngas derived from coal gasification even though the real syngas from coal gasification may be different from the protocol.

Table 3: DOE test protocol gas compositions.

\begin{tabular}{lccc}
\hline Feed gas species & Test 1 Composition & Test 2A Composition & Test 3* Composition \\
\hline $\mathrm{H}_{2}(\%)$ & 50 & 50 & 20 \\
$\mathrm{CO}(\%)$ & 1 & 1 & 21 \\
$\mathrm{CO}_{2}(\%)$ & 30 & 30 & 12 \\
$\mathrm{H}_{2} \mathrm{O}(\%)$ & 19 & 19 & 47 \\
$\mathrm{H}_{2} \mathrm{~S}(\%)$ & 0 & 0.002 & 0.002 \\
\hline
\end{tabular}

\subsection{UTRC Corrosion Testing}

Laboratory corrosion testing at exposure times up to 2000 hours was completed at UTRC on eight different alloys. The purpose of this testing was to identify alternative non-membrane materials of construction for long-term durability when operated under DOE Test 2A conditions. A total of eight alloys were evaluated in these tests and each alloy consisted of triplicate coupons. Each alloy coupon was cut to approximately $20 \mathrm{~mm} \times 20 \mathrm{~mm}$ and ground to a 600 grit 
finish using $\mathrm{SiC}$ paper. A hole was drilled in the top center of each coupon to hang the alloy samples from an alumina rod during exposure testing. Prior to exposure, samples were passivated to remove free iron from drilling following the procedures in the ASTM A380 specification.

All alloys were tested at $500{ }^{\circ} \mathrm{C}$ in an IR tubular furnace in a modified Test $2 \mathrm{~A}$ gas. To simulate the equivalent of $20 \mathrm{ppmv}_{2} \mathrm{~S}$ at 200 psia, the corrosion rig at UTRC used a feed gas composition containing an $\mathrm{H}_{2} \mathrm{~S}$ concentration of $272 \mathrm{ppmv}$, as well as $50 \% \mathrm{H}_{2}, 30 \% \mathrm{CO}_{2}, 19 \%$ $\mathrm{H}_{2} \mathrm{O}$ and $1 \% \mathrm{CO}$ at 14.696 psia. The total gas flow rate was $0.5 \mathrm{~L} \mathrm{~min}^{-1}$, which enabled longterm laboratory testing from gas cylinders. Samples were cooled and weighed periodically to determine the weight gain and oxidation/corrosion kinetics as a function of time.

\subsection{EERC Gasifier Testing}

Two different gasifiers were used to produce syngas for membrane testing at EERC. The primary one used for this work was the fluid-bed gasifier (FBG), a pilot-scale unit constructed based on EERC's years of bench-scale fluidized bed gasifiers. For one test campaign in January 2011, the much larger transport reactor development unit (TRDU) gasifier was also used to produce syngas.

The FBG is capable of feeding up to $9.0 \mathrm{~kg} \mathrm{~h}^{-1}\left(20 \mathrm{lb} \mathrm{h}^{-1}\right)$ of pulverized coal or biomass at pressures up to 70 bar absolute (1000 psig). The externally heated bed is initially charged from an independent hopper with silica sand or, in the case of high-alkali fuels, an appropriate fluidization media. Independent mass flow controllers meter the flow of nitrogen, oxygen, steam, and recycled syngas into the bottom of the fluid bed. Various safety interlocks prevent the inadvertent flow of pure oxygen into the bed or of reverse flow into the coal feeder. Recycled syngas is injected several inches above the bottom distributor plate, which prevents direct combustion of syngas with oxygen entering at the bottom of the bed.

For separator testing, EERC constructed a membrane test system which is located downstream of EERC's pilot-scale gasifiers, including the FBG. Steam was mixed with the syngas produced from the FBG and the gas mixture was fed through two beds of KATALCOJM ${ }^{\mathrm{TM}}$ K8-11 sour-shift catalyst. After the shift beds, the converted syngas was passed over a bed of RVS-1 regenerable sorbent to remove sulfur and other trace contaminants. The exhaust gas from the sorbent bed was then fed directly to the EERC membrane test skid. Up to three separators could be installed in the membrane test skid where the syngas flow could be split and independently controlled for each membrane. The membrane test skid contained all of the necessary instrumentation, controls, and heaters necessary to maintain the gas flow, pressure, and temperature of the separators.

Multiple methods were used to measure the composition of the gases entering and exiting the separators. Gas chromatographs and laser Raman continuous analyzers were used to measure the concentration of the main syngas constituents after passing through water-cooled condensers (quench pots) to remove water and other trace condensables. In addition, Dräger tubes were used to quantify the gas sulfur concentration during all runs. Dräger tubes were also used periodically to check other gas contaminants, such as $\mathrm{NH}_{3}, \mathrm{HCN}$, and $\mathrm{HCl}$. Analysis of the feed gas for trace metals was performed less frequently to determine the concentration of other gas contaminants, such as mercury $(\mathrm{Hg})$.

The TRDU is a gasification unit capable of producing up to $400 \mathrm{lb}_{\text {day }}{ }^{-1} \mathrm{H}_{2}$. The TRDU at EERC has an operating temperature of up to $1040^{\circ} \mathrm{C}$ and an operating pressure of approximately 120 psig. Because the TRDU is in a different location on the EERC campus, the membrane test 
system was moved to the TRDU gasification tower for the January 2011 experimental campaign. The lower operating pressure of the TRDU required a modification of the test setup. A slipstream of syngas from the TRDU was taken after hot gas filtration and pulled through heat traced lines at $289^{\circ} \mathrm{C}$. Steam was mixed with the syngas and the gas mixture was fed through the two beds of KATALCOJM ${ }^{\mathrm{TM}}$ K8-11 sour-shift catalyst. After the shift beds, the converted syngas was passed over a bed of RVS-1 regenerable sorbent to remove sulfur and other trace contaminants. The exhaust gas from the sorbent bed was then cooled in a series of quench pots to remove moisture prior to compression in a gas booster system. The higher pressure gas was then fed to the EERC membrane test skid.

\section{Results}

\subsection{Impact of Syngas Species and $\mathrm{H}_{2} \mathrm{~S}$ on $\mathrm{H}_{2}$ Permeation}

The Hydrogen Economy has drawn wide attention for its potential for sustainable and renewable energy. Vast coal reserves and renewable biomass have also aroused an interest in coal gasification and biomass pyrolysis and hydrolysis to produce molecular hydrogen $\left(\mathrm{H}_{2}\right)$ or liquid fuels. Hydrogen is widely considered as a better energy carrier since it can provide electricity through fuel cells which is more efficient and cleaner compared to electricity production from a conventional coal power plant.

An efficient $\mathrm{H}_{2}$ separation technology is needed for the Hydrogen Economy to separate $\mathrm{H}_{2}$ from syngas, which can be produced by a variety of technologies such as coal gasification and fossil fuel reforming [3]. Palladium (Pd) and its alloy membranes have been increasingly investigated for $\mathrm{H}_{2}$ separation in recent years because membrane separation technology may offer more potential advantages over traditional separation technologies.

Membrane applications in the petroleum industry for separation and reaction processes were recently reviewed [4]. A Pd membrane reactor was also explored in a solid oxide fell cell (SOFC) system to improve system efficiency by replacing a conventional methane reformer. The use of a Pd membrane reactor resulted in an improvement of the maximum SOFC power density of $25 \%$ compared to a conventional reformer [5].

The transport of $\mathrm{H}_{2}$ through a thin film of Pd is well known and described as Sievert's law with an assumption of hydrogen diffusion through the bulk of the palladium as a rate-limiting step [6]. $\mathrm{H}_{2}$ permeation was observed to follow Sievert's law in most of the work published, indicating that hydrogen diffusion through the bulk Pd is the rate-limiting step. Some deviations of $\mathrm{H}_{2}$ permeation through $\mathrm{Pd}$ membranes were also reported due to either some membrane defects or very thin membranes. This resulted from the alteration of the rate-limiting step from the $\mathrm{H}_{2}$ diffusion through the bulk of $\mathrm{Pd}$ to another step. The rate-limiting step in the $\mathrm{H}_{2}$ transport through a Pd membrane can also be affected by operating conditions (temperature, pressure, etc.) and membrane properties (thickness and $\mathrm{H}_{2}$ permeability). Pd membranes thicker than $1 \mu \mathrm{m}$ were still expected to have $\mathrm{H}_{2}$ diffusion through the $\mathrm{Pd}$ as the rate-limiting step at temperatures above $300{ }^{\circ} \mathrm{C}$ in the absence of external mass transfer [7].

Impurities in real syngas derived from coal gasification can affect Pd membrane performance for $\mathrm{H}_{2}$ separation. Hydrogen sulfide $\left(\mathrm{H}_{2} \mathrm{~S}\right)$ in the syngas was reported to significantly reduce the $\mathrm{H}_{2}$ flux of a $\mathrm{Pd}$ membrane. To mitigate the $\mathrm{H}_{2} \mathrm{~S}$ impact on $\mathrm{Pd}$ membrane performance, palladium-copper $(\mathrm{Pd}-\mathrm{Cu})$ alloy and palladium-gold $(\mathrm{Pd}-\mathrm{Au})$ alloy membranes were shown to be sulfur (S) tolerant by the pioneering work of McKinley [8,9]. It was recently reported that an 80 wt.\% $\mathrm{Pd}-20$ wt. \% Cu alloy membrane had a higher $\mathrm{H}_{2}$ permeance than 60 wt.\% $\mathrm{Pd}-40$ 
wt. $\% \mathrm{Cu}$ in the presence of $1000 \mathrm{ppmv} \mathrm{H}_{2} \mathrm{~S}$ at temperatures above $560{ }^{\circ} \mathrm{C}$ [10] due to a phase transformation. The $80 \mathrm{wt} . \% \mathrm{Pd}-20 \mathrm{wt} . \% \mathrm{Cu}$ alloy membrane had a face-centered cubic (fcc) structure while the $60 \mathrm{wt} . \% \mathrm{Pd}-40 \mathrm{wt} . \% \mathrm{Cu}$ had a body-centered cubic (bcc) structure. At temperatures above $560{ }^{\circ} \mathrm{C}$, the $60 \mathrm{wt} . \% \mathrm{Pd}-40 \mathrm{wt} . \% \mathrm{Cu}$ alloy membrane with a bcc structure was transformed into an fcc structure. First-principle modeling also showed a fcc $\mathrm{Pd}-\mathrm{Cu}$ alloy membrane with more than 75 mol.\% Pd could be more sulfur tolerant [11].

A more recent study showed that a thin $\mathrm{Pd}-\mathrm{Cu}$ alloy membrane applied on top of a thin $\mathrm{Pd}$ membrane deposited onto a porous stainless steel support gave a relatively high $\mathrm{H}_{2}$ permeability [12]. The membrane was observed to have $93 \%$ of the $\mathrm{H}_{2}$ permeability of a pure Pd foil at the same thickness while the previous $\mathrm{Pd}-\mathrm{Cu}$ membranes gave about $50-60 \%$ of the permeability compared to pure Pd foils [12]. Pd-Au membranes were also tested for sulfur resistance [13, 14]. It was also shown by McKinley [8] that a $5 \mathrm{wt} . \% \mathrm{Au}-95 \mathrm{wt} . \% \mathrm{Pd}$ alloy membranes showed good $\mathrm{H}_{2}$ permeability. A Pd-Au alloy membrane with $8 \mathrm{wt} . \%$ Au showed resistance to bulk sulfidation upon exposure to a $54.8 \mathrm{ppmv} \mathrm{H}_{2} \mathrm{~S}-\mathrm{H}_{2}$ mixture in the temperature range of $350{ }^{\circ} \mathrm{C}-500{ }^{\circ} \mathrm{C}$ but a $\mathrm{H}_{2}$ permeance decline was also observed [13]. A 33- $\mu \mathrm{m}, 80 \mathrm{wt} . \% \mathrm{Pd}-10 \mathrm{wt} . \% \mathrm{Au}-10$ wt.\% platinum (Pt) membrane was evaluated with syngas and a $\mathrm{H}_{2}$ permeance decline of approximately $21 \% \mathrm{H}_{2}$ flux decline was observed once 20 ppmv $\mathrm{H}_{2} \mathrm{~S}$ was added into the feed [14].

Thermodynamic calculations of a Pd-Cu alloy system with $\mathrm{H}_{2} \mathrm{~S}$ in $\mathrm{H}_{2}$ gas revealed that thermodynamically stable palladium sulfide $\left(\mathrm{Pd}_{4} \mathrm{~S}\right)$ and unstable $\mathrm{Pd}_{4} \mathrm{~S}$ could be formed and the threshold required for the formation of thermodynamically stable $\mathrm{Pd}_{4} \mathrm{~S}$ was identified as a function of temperature and molar $\mathrm{H}_{2} \mathrm{~S}-$ to- $\mathrm{H}_{2}$ ratio in the gas phase [15]. The experimental results indicated that thermodynamically stable sulfides were formed when the $\mathrm{H}_{2} \mathrm{~S}-$ to- $-\mathrm{H}_{2}$ ratio in the feed was above the threshold level, causing failure of the Pd and $60 \mathrm{wt} . \% \mathrm{Pd}-40 \mathrm{wt} . \% \mathrm{Cu}$ membrane reactors [16]. Significant loss of $\mathrm{H}_{2}$ permeance was observed for a $60 \mathrm{wt} \% \mathrm{Pd}-$ 40 wt.\% $\mathrm{Cu}\left(47 \mathrm{~mol} \% \% \mathrm{Pd}-53 \mathrm{~mol} \% \mathrm{Cu}\right.$ ) membrane exposed to a $1000 \mathrm{ppmv}_{2} \mathrm{~S}$ in the $90 \%$ $\mathrm{H}_{2}-\mathrm{He}$ feed at temperatures less than $560{ }^{\circ} \mathrm{C}$ [10]. When a stable $\mathrm{Pd}_{4} \mathrm{~S}$ was formed in a $\mathrm{Pd}-\mathrm{Cu}$ alloy membrane, the membrane was observed to fail [17].

Other species in syngas such as nitrogen $\left(\mathrm{N}_{2}\right)$, carbon monoxide $(\mathrm{CO})$, carbon dioxide $\left(\mathrm{CO}_{2}\right)$ and water $\left(\mathrm{H}_{2} \mathrm{O}\right)$ were reported to affect $\mathrm{H}_{2}$ permeability of Pd membranes [18-21]. In particular, $\mathrm{CO}$ in the $\mathrm{H}_{2}$ gas mixture caused a decline in $\mathrm{H}_{2}$ permeability for $\mathrm{Pd}-\mathrm{Ag}$ membranes at temperatures up to $274{ }^{\circ} \mathrm{C}$, which was described by a modified Sievert's law equation [18]. This impact was attributed to $\mathrm{CO}$ adsorption on the surface of the membranes. The inhibition magnitudes of $\mathrm{CO}, \mathrm{CO}_{2}$ and $\mathrm{H}_{2} \mathrm{O}$ on $\mathrm{H}_{2}$ permeation through the $\mathrm{Pd}-\mathrm{Ag}$ membranes was in the order $\mathrm{H}_{2} \mathrm{O}>\mathrm{CO}>\mathrm{CO}_{2}$. This was related to their adsorption capacity on the membrane surface, suggesting that the $\mathrm{H}_{2}$ permeation inhibition was due to the competitive adsorption of these species on the membrane surface [22].

External mass transfer can be one of the major issues to affect $\mathrm{H}_{2}$ permeation through a $\mathrm{Pd}$ membrane. Innovative design of a membrane assembly along with a careful choice of operating conditions can minimize the external mass transfer resistance in a $\mathrm{H}_{2}$ separation process. Experimental data and modeling indicated that external mass transfer resistance was not significant for $\mathrm{H}_{2}-\mathrm{N}_{2}$ gas mixtures through a $5 \mu \mathrm{m}$ to $6 \mu \mathrm{m}$ thick Pd-Ag membrane when the feed gas velocity was more than $100 \mathrm{~cm} / \mathrm{s}$ [22].

\subsubsection{Permeance of pure $\mathrm{H}_{2}$}

$\mathrm{H}_{2}$ permeation through a Pd membrane is described by the well-known Sievert's law, which is expressed by Equation (1) when the $\mathrm{H}_{2}$ diffusion through the bulk of Pd membrane is the rate- 
limiting step. In this equation, $F_{H_{2}}$ is the $\mathrm{H}_{2}$ permeation flux (mol m $\mathrm{m}^{-2}$ ); $Q_{\mathrm{H}_{2}}$ is the $\mathrm{H}_{2}$ permeability (mol m $\mathrm{s}^{-1} \mathrm{~Pa}^{-0.5}$ ); and $P_{f}$ and $P_{p}$ are the $\mathrm{H}_{2}$ pressures $(\mathrm{Pa})$ on the feed and permeate sides, respectively.

$$
F_{H_{2}}=\frac{Q_{H_{2}}}{l}\left(P_{f}^{0.5}-P_{p}^{0.5}\right)
$$

Equation (1) can also be expressed as Equation (2), where $Q_{0 \mathrm{H}_{2}}$ is the $\mathrm{H}_{2}$ permeability coefficient ( $\left.\mathrm{mol} \mathrm{m} \mathrm{s}^{-1} \mathrm{~Pa}^{-0.5}\right) ; E$ is the $\mathrm{H}_{2}$ permeation activation energy $\left(\mathrm{J} \mathrm{mol}^{-1}\right) ; T$ is the temperature $(\mathrm{K})$; $\mathrm{R}$ is the gas constant $\left(\mathrm{J} \mathrm{mol}^{-1} \mathrm{~K}^{-1}\right)$; and $l$ is the membrane thickness $(\mathrm{m})$.

$$
F_{H_{2}}=\frac{Q_{0 H_{2}} \exp \left(-\frac{E}{R T}\right)}{l}\left(P_{f}^{0.5}-P_{p}^{0.5}\right)
$$

Testing of a Pd-Cu alloy separator (5276, see Table 2) was started with heating the $\mathrm{Pd}-\mathrm{Cu}$ separator from room temperature to $300{ }^{\circ} \mathrm{C}$ in a $\mathrm{N}_{2}$ atmosphere at a heating rate of about 4 ${ }^{\circ} \mathrm{C} /$ min and then switching to pure $\mathrm{H}_{2}$. The pure $\mathrm{H}_{2}$ experiments were conducted with varying temperatures between $350{ }^{\circ} \mathrm{C}$ and $500{ }^{\circ} \mathrm{C}$ and pressures from about 2.03 bar to 13.79 bar to evaluate how the $\mathrm{H}_{2}$ permeation of the $\mathrm{Pd}-\mathrm{Cu}$ separator performed. Figure 3 shows the Arrhenius plot of the natural $\log$ of $\mathrm{H}_{2}$ permeability against the reciprocal temperature. The natural $\log$ of $\mathrm{H}_{2}$ permeability increased linearly with the reciprocal temperature.

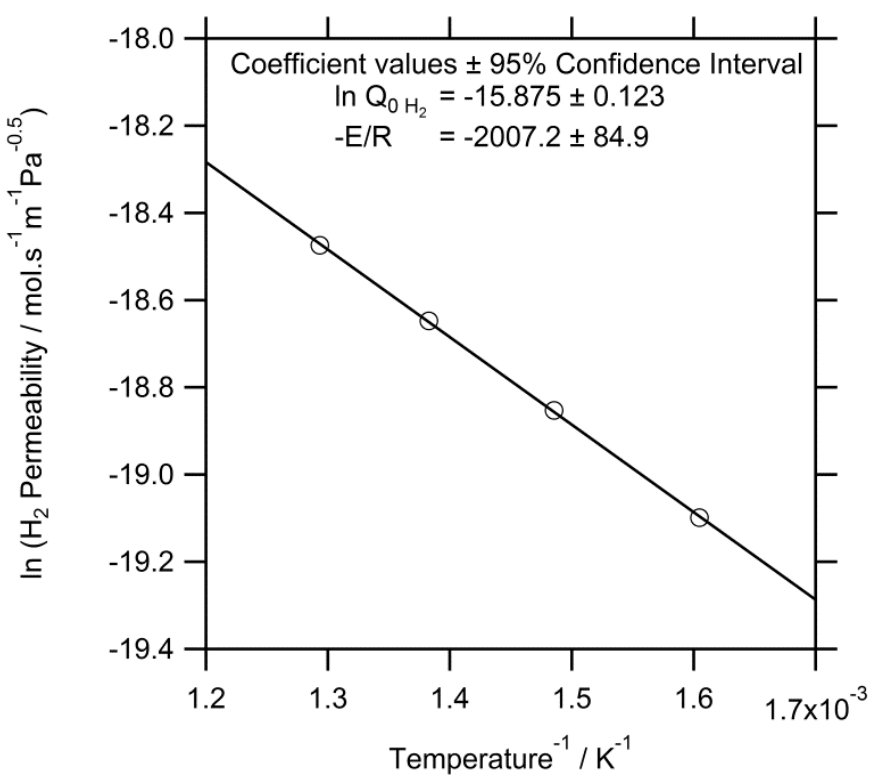

Figure 3: Arrhenius plot of pure $\mathrm{H}_{2}$ through a $\mathrm{Pd}-\mathrm{Cu}$ alloy separator.

From the slope and intercept of the straight line shown in Figure 3, the $\mathrm{H}_{2}$ permeability coefficient and activation energy were calculated to be $1.28 \times 10^{-7} \mathrm{~mol} /\left(\mathrm{m} \mathrm{s} \mathrm{Pa}^{0.5}\right)$ and $1.669 \times 10^{4} \mathrm{~J} / \mathrm{mol}$, respectively. Higher values for these two parameters were also observed for Pd membranes in other literature $[23,24]$. Values of $1.92 \times 10^{-7} \mathrm{~mol} /\left(\mathrm{m} \mathrm{s} \mathrm{Pa}^{0.5}\right)$ and $1.38 \times 10^{4} \mathrm{~J} / \mathrm{mol}$ were reported for bulk Pd membranes at temperatures between $350{ }^{\circ} \mathrm{C}$ and $900{ }^{\circ} \mathrm{C}$ (about $1-\mathrm{mm}$ thickness) [23]. The experimental results showed a $\mathrm{H}_{2}$ permeability coefficient of 
$3.82 \times 10^{-7} \mathrm{~mol} /\left(\mathrm{m} \mathrm{s} \mathrm{Pa}^{0.5}\right)$ and activation energy of $2.0 \times 10^{4} \mathrm{~J} / \mathrm{mol}$ for $940-\mu \mathrm{m}$ thick $\mathrm{Pd}$ membranes at temperatures ranging from $496^{\circ} \mathrm{C}$ to $946^{\circ} \mathrm{C}$ [24].

\subsection{2 $\mathrm{H}_{2}$ Permeance of $\mathrm{H}_{2}$ gas mixtures}

In order to investigate the effect of non-hydrogen species in syngas on the $\mathrm{H}_{2}$ permeation of the lab-scale Pd-Cu separator, binary $\mathrm{H}_{2}$ gas mixtures with $\mathrm{N}_{2}, \mathrm{CO}, \mathrm{CO}_{2}$, and $\mathrm{H}_{2} \mathrm{O}$, respectively were sequentially introduced into the system at temperatures between $400{ }^{\circ} \mathrm{C}$ and $500{ }^{\circ} \mathrm{C}$ after the pure $\mathrm{H}_{2}$ permeation experiment was conducted. During these tests, the $\mathrm{H}_{2}$ concentration was varied from $60 \%$ to $100 \%$; the $\mathrm{N}_{2}$ concentration was varied from $10 \%$ to $40 \%$; the $\mathrm{CO}_{2}$ concentration was varied from $10 \%$ to $30 \%$; and the $\mathrm{H}_{2} \mathrm{O}$ concentration was varied from $7 \%$ to $36 \%$. For the mixture of $\mathrm{H}_{2}$ and $\mathrm{CO}$, coke formation would be thermodynamically favored if the $\mathrm{O} / \mathrm{C}$ and $\mathrm{H} / \mathrm{C}$ of the mixture is in the coking regime. As a result, the testing of the $\mathrm{H}_{2}-\mathrm{CO}$ binary mixture was conducted with the addition of $\mathrm{H}_{2} \mathrm{O}$ to avoid the coking regime. The $\mathrm{CO}$ concentration was also varied from $0.5 \%$ to $2.1 \%$ (the region around $1 \%$ defined in the DOE Test Protocol, see Table 3 ) in the presence of $\mathrm{H}_{2} \mathrm{O}$ in concentrations of $0.9 \%$ to $4.5 \%$.

The results of $\mathrm{H}_{2}$ permeation of these gas mixtures through the $\mathrm{Pd}-\mathrm{Cu}$ separator along with the pure $\mathrm{H}_{2}$ at $400{ }^{\circ} \mathrm{C}$ are shown in Figure 4. The $\mathrm{H}_{2}$ permeation fluxes from pure $\mathrm{H}_{2}$ and all $\mathrm{H}_{2}$ mixtures against the $\mathrm{H}_{2}$ partial pressure square root driving force were roughly linear. The $\mathrm{H}_{2}$ permeation of these gas mixtures with the above compositions at $400{ }^{\circ} \mathrm{C}$ showed a behavior close to that of pure $\mathrm{H}_{2}$, in which the $\mathrm{H}_{2}$ flux increased linearly with the $\mathrm{H}_{2}$ partial pressure square root driving force. This indicated that there was no inhibition effect on the $\mathrm{H}_{2}$ permeability from $\mathrm{N}_{2}, \mathrm{CO}, \mathrm{CO}_{2}$, and $\mathrm{H}_{2} \mathrm{O}$, suggesting that the $\mathrm{H}_{2}$ permeation of the $\mathrm{Pd}-\mathrm{Cu}$ membrane still followed the Sievert's Law dependence. This also implied that hydrogen diffusion through the bulk of the $\mathrm{Pd}-\mathrm{Cu}$ alloy was the rate-liming step in the $\mathrm{H}_{2}$ transport through the separator, with the external mass transfer resistance being insignificant.

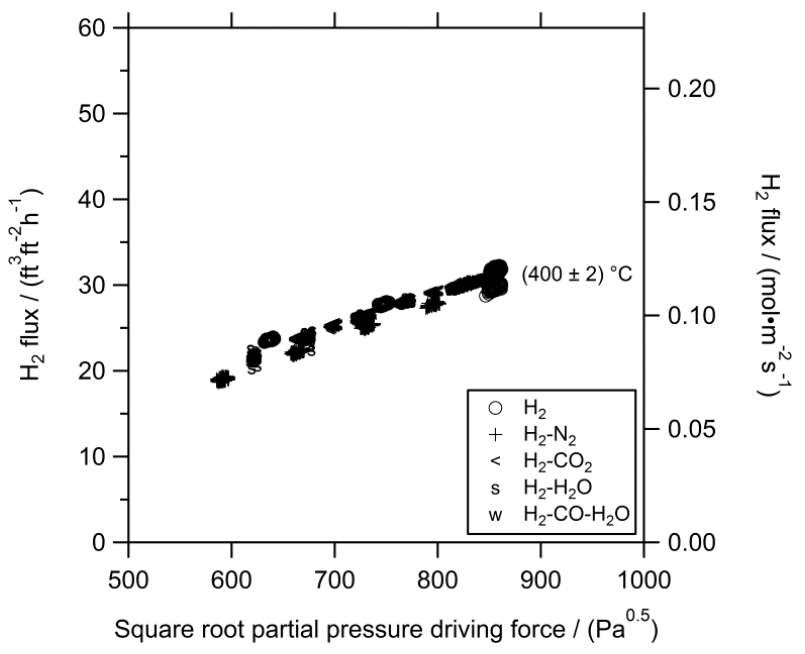

Figure 4: $\mathrm{H}_{2}$ flux versus $\mathrm{H}_{2}$ square root driving force for different gas mixtures at $400{ }^{\circ} \mathrm{C}$.

In contrast, the inhibition effect from $\mathrm{CO}, \mathrm{CO}_{2}$ and $\mathrm{H}_{2} \mathrm{O}$ on the $\mathrm{H}_{2}$ permeability of $\mathrm{Pd}$ and $\mathrm{Pd}-$ Ag membranes was reported [18, 20,21]. This inhibition effect was believed to contribute to CO adsorption on the membrane surface and the Sievert-Langmuir's equation was proposed [18], as described by Equation (3). 


$$
H_{2} \text { flux }=\left(1-\alpha(T) \frac{K_{C O} P_{C O}}{1+K_{C O} P_{C O}}\right) \pi_{0} e^{-E a / R T}\left(\sqrt{P_{H_{2}}^{\text {Feed }}}-\sqrt{P_{H_{2}}^{\text {Permeate }}}\right)
$$

This equation adapted and modified Sievert's law by using a dimensionless factor,

$$
\alpha(T) \frac{K_{C O} P_{C O}}{1+K_{C O} P_{C O}}
$$

to account for the $\mathrm{CO}$ adsorption effect on the $\mathrm{H}_{2}$ permeation. More recently, Equation (3) was modified by incorporating the concentration polarization coefficient (CPC) and inhibition coefficient (IC) into the permeation reduction coefficient (PRC), as described by Equations (4) and (5) [25]. The experimental results showed the significant decline of the $\mathrm{H}_{2}$ permeance from a $90 \% \mathrm{H}_{2}-10 \% \mathrm{CO}$ mixture at $374{ }^{\circ} \mathrm{C}$ at a feed pressure of $340 \mathrm{kPa}$, but the $\mathrm{H}_{2}$ permeance from $90 \% \mathrm{H}_{2}-10 \% \mathrm{CO}_{2}$ and $90 \% \mathrm{H}_{2}-10 \% \mathrm{~N}_{2}$ mixtures at $374{ }^{\circ} \mathrm{C}$ followed Sievert's law, indicating that $\mathrm{CO}$ had a strong effect on the $\mathrm{H}_{2}$ permeation but that $\mathrm{CO}_{2}$ and $\mathrm{N}_{2}$ did not affect the $\mathrm{H}_{2}$ permeation at those testing conditions [18].

$$
\begin{gathered}
H_{2} \text { flux }=\left[(1-P R C) \pi_{0} e^{-E a / R T}\right]\left(\sqrt{P_{H_{2}}^{\text {Feed }}}-\sqrt{P_{H_{2}}^{\text {Permeate }}}\right) \\
\text { PRC }=1-(1-\mathrm{CPC})(1-\mathrm{IC})
\end{gathered}
$$

Similarly, the inhibition model of $\mathrm{CO}$ and $\mathrm{CO}_{2}$ on the $\mathrm{H}_{2}$ permeation was also considered in a high pressure membrane reactor for the high temperature water-gas shift reaction due to adsorption phenomena as a Langmuir's equation more recently [26]. This is described in Equation (6), where $P m_{0}$ is the permeance of the membrane for pure $\mathrm{H}_{2}$ and $P m$ is the permeance of the membrane when other gases are present. In essence, the $\mathrm{H}_{2}$ permeance for a $\mathrm{H}_{2}$ mixture could be less than that for pure $\mathrm{H}_{2}$ due to competitive adsorption. The authors' previous work presented the effective $\mathrm{H}_{2}$ permeability of the $\mathrm{Pd}-\mathrm{Cu}$ membranes for the feed of simulated syngas $[27,28]$ as shown in Equation (7). In this Equation, $K_{i}$ is the adsorption constant of component $i$; $p_{i}$ is the partial pressure of component $i$; $Q_{\text {eff }}$ and $Q_{H 2 O}$ are the effective $\mathrm{H}_{2}$ permeability from a $\mathrm{H}_{2}$ gas mixture and the $\mathrm{H}_{2}$ permeability from pure $\mathrm{H}_{2}$, respectively; and $a$ is a deactivation factor.

$$
\begin{gathered}
P m=\frac{P m_{0}}{1+A_{C O} P_{C O}+A_{\mathrm{CO}_{2}} P_{\mathrm{CO}_{2}}} \\
Q_{e f f}=\frac{a Q_{0}}{1+\sum K_{i} p_{i}}=\frac{a Q_{\mathrm{H}_{2} \mathrm{O}}}{1+K_{\mathrm{CO}} p_{\mathrm{CO}}+K_{\mathrm{CO}_{2}} p_{\mathrm{CO}_{2}}+K_{\mathrm{H}_{2} \mathrm{O}} p_{\mathrm{H}_{2} \mathrm{O}}+K_{\mathrm{N}_{2}} p_{\mathrm{N}_{2}}}
\end{gathered}
$$

The experimental $\mathrm{H}_{2}$ permeation results of the $\mathrm{H}_{2}$ gas mixtures at $450{ }^{\circ} \mathrm{C}$ and $500{ }^{\circ} \mathrm{C}$ are shown in Figure 5 and Figure 6, respectively. As expected, the trend was similar to that observed at $400{ }^{\circ} \mathrm{C}$. The $\mathrm{H}_{2}$ fluxes from all $\mathrm{H}_{2}$ gas mixtures were very close to that from pure $\mathrm{H}_{2}$ at the same $\mathrm{H}_{2}$ pressure driving force and $\mathrm{H}_{2}$ fluxes increased with the $\mathrm{H}_{2}$ partial pressure square root driving force, indicating that Sievert's law was still valid for the $\mathrm{H}_{2}$ gas mixtures. 


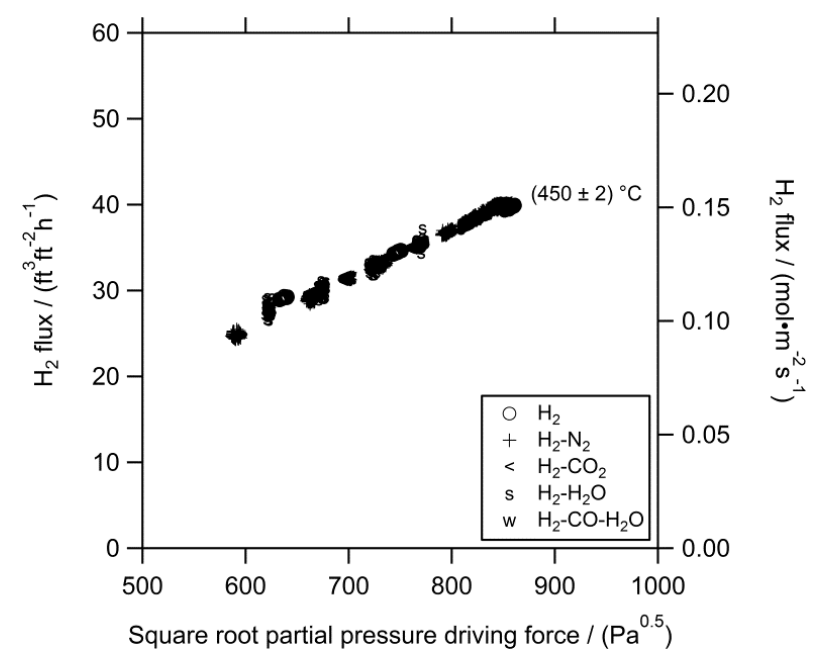

Figure 5: $\mathrm{H}_{2}$ flux versus $\mathrm{H}_{2}$ square root driving force for different gas mixtures at $450{ }^{\circ} \mathrm{C}$.

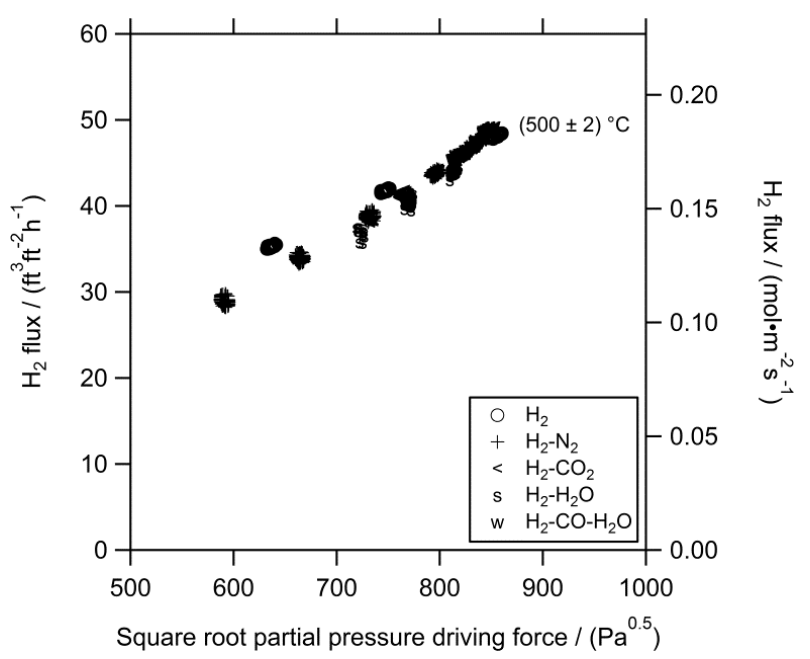

Figure 6: $\mathrm{H}_{2}$ flux versus $\mathrm{H}_{2}$ square root driving force for different gas mixtures at $500{ }^{\circ} \mathrm{C}$.

In order to further investigate the effect of the non-hydrogen species in syngas on the $\mathrm{H}_{2}$ permeability of the Pd-Cu alloy separator, a pilot-scale Pd-Cu alloy separator (5312, see Table 2) was tested at temperatures between $350{ }^{\circ} \mathrm{C}$ and $500{ }^{\circ} \mathrm{C}$ at a pressure of 6.89 bar for $\mathrm{H}_{2}$ mixtures of $50 \% \mathrm{H}_{2}$ with $50 \% \mathrm{~N}_{2} ; 50 \% \mathrm{H}_{2} \mathrm{O}$; and $16 \% \mathrm{CO} / 34 \% \mathrm{H}_{2} \mathrm{O}$, respectively. Figure 7 shows the Arrhenius plot of $\mathrm{H}_{2}$ permeation from the above $\mathrm{H}_{2}$ mixtures versus reciprocal temperature. At temperatures of $400{ }^{\circ} \mathrm{C}, 450{ }^{\circ} \mathrm{C}$ and $500{ }^{\circ} \mathrm{C}$, it appeared that the $\mathrm{H}_{2}$ fluxes from all three $50 \% \mathrm{H}_{2}$ mixtures were nearly identical, indicating that there was no inhibition effect from $\mathrm{N}_{2}, \mathrm{CO}$, and $\mathrm{H}_{2} \mathrm{O}$, confirming the observations from the lab-scale $\mathrm{Pd}-\mathrm{Cu}$ separator. However, it was clear that there was inhibition from the gas mixtures on the $\mathrm{H}_{2}$ permeation at $350{ }^{\circ} \mathrm{C}$ due to a deviation from the Arrhenius fit at higher temperatures. It appeared that adsorption of $\mathrm{CO}, \mathrm{H}_{2} \mathrm{O}$ and $\mathrm{N}_{2}$ on the $\mathrm{Pd}-\mathrm{Cu}$ membrane surface at this temperature started to compete with $\mathrm{H}_{2}$ transport through the membrane, inhibiting $\mathrm{H}_{2}$ permeation. Temperature has the opposite effect on gas adsorption versus $\mathrm{H}_{2}$ transport through a $\mathrm{Pd}$ membrane. Thus, the data suggest that low temperatures favors stronger gas adsorption but reduces $\mathrm{H}_{2}$ permeation through the $\mathrm{Pd}$ membrane. As a result, no inhibition from $\mathrm{N}_{2}, \mathrm{CO}$, and $\mathrm{H}_{2} \mathrm{O}$ was observed at temperatures between $400{ }^{\circ} \mathrm{C}$ and $500{ }^{\circ} \mathrm{C}$, but 
the inhibition from these gases appeared to be visible when the temperature was dropped to $350{ }^{\circ} \mathrm{C}$.

In addition, the permeability and thickness of a Pd or Pd alloy membrane plays a role in the determination of a rate-limiting step during hydrogen transport through the membrane. A membrane with a greater thickness and a low $\mathrm{H}_{2}$ permeability reduces the $\mathrm{H}_{2}$ permeation flux relative to an external mass transfer resistance on the $\mathrm{H}_{2}$ transport through the entire membrane. Concentration polarization (external mass transfer) occurrence was revealed by a simulation analysis for thinner $(1 \mu \mathrm{m}$ to $5 \mu \mathrm{m}) \mathrm{Pd}$ membranes for most cases and some cases with a thicker $(\approx 100 \mu \mathrm{m})$ membrane [29]. Thus, the self-supported Pd-Cu alloy separators tested in this study with a relatively greater thickness $(45.8 \mu \mathrm{m}$ for the lab-scale separator and $58.6 \mu \mathrm{m}$ for the pilotscale scale separator) for mechanical strength at higher pressures, along with $\mathrm{P}+\mathrm{E}$ 's proprietary design, did not result in significant decreases in $\mathrm{H}_{2}$ permeance due to external transport resistances or gas contaminants.

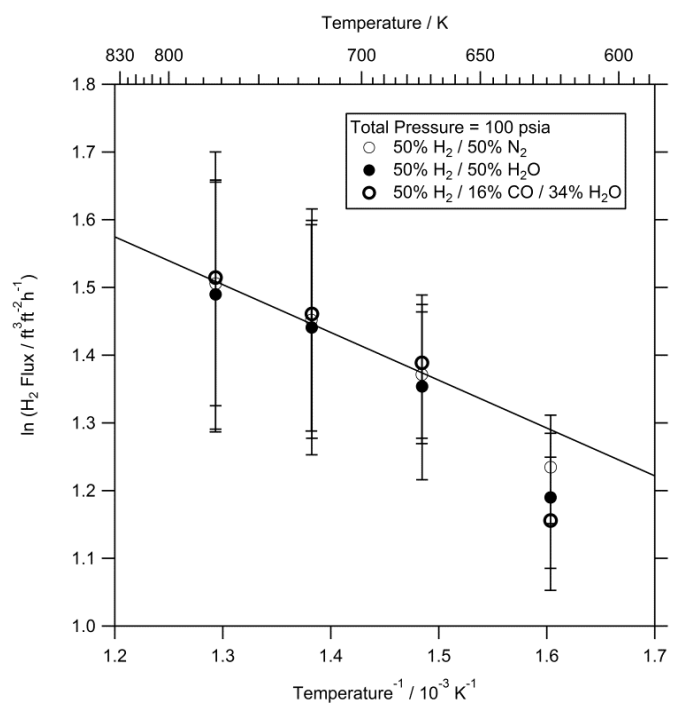

Figure 7: Arrhenius plot of $\mathrm{H}_{2}$ permeation from $\mathrm{H}_{2}$ mixtures through a pilot-scale separator.

\subsection{3 $\mathrm{H}_{2}$ Permeance of $\mathrm{H}_{2}$ gas mixtures with $\mathrm{H}_{2} \mathrm{~S}$}

One of the major objectives of this work was to demonstrate that the $\mathrm{Pd}-\mathrm{Cu}$ separator was sulfur tolerant. Since no major impact of non- $\mathrm{H}_{2}$ species $\left(\mathrm{N}_{2}, \mathrm{CO}, \mathrm{CO}_{2}\right.$, and $\left.\mathrm{H}_{2} \mathrm{O}\right)$ on the $\mathrm{H}_{2}$ permeation flux was observed at temperatures between $400{ }^{\circ} \mathrm{C}$ and $500{ }^{\circ} \mathrm{C}, \mathrm{H}_{2} \mathrm{~S}$ concentrations between 5 ppmv and 39 ppmv were added into the $\mathrm{H}_{2}$ gas mixtures conducted in non-sulfur gas mixture experiments to explore how the $\mathrm{Pd}-\mathrm{Cu}$ separator performed.

For comparison, the $\mathrm{H}_{2}$ fluxes were plotted against the square root of the $\mathrm{H}_{2}$ partial pressures for the $\mathrm{H}_{2}$ gas mixtures with and without $\mathrm{H}_{2} \mathrm{~S}$. The experimental results at the temperatures of $400{ }^{\circ} \mathrm{C}, 450{ }^{\circ} \mathrm{C}$, and $500{ }^{\circ} \mathrm{C}$ are shown in Figure 8, Figure 9, and Figure 10, respectively. It was clear that the $\mathrm{H}_{2}$ fluxes of these gas mixtures were nearly identical with and without the addition of $\mathrm{H}_{2} \mathrm{~S}$. This indicated that the Pd-Cu separator tested was not affected by $\mathrm{H}_{2} \mathrm{~S}$ and was sulfur tolerant at the testing conditions.

One of the major factors affecting $\mathrm{H}_{2}$ permeation through a $\mathrm{Pd}-\mathrm{Cu}$ alloy membrane might be the ratio of $\mathrm{H}_{2} \mathrm{~S}$-to- $\mathrm{H}_{2}$ in the feed as indicated by thermodynamic calculations [15]. These calculations gave the plot of the ratio of $\mathrm{H}_{2} \mathrm{~S}-$ to- $\mathrm{H}_{2}$ as a function of temperature for the formation 
of thermodynamically stable and unstable $\mathrm{Pd}_{4} \mathrm{~S}$ for the $\mathrm{Pd}-\mathrm{Cu}$ and $\mathrm{H}_{2} \mathrm{~S}$ system. Sulfide formation was considered to contribute to $\mathrm{H}_{2}$ permeability reduction for $\mathrm{Pd}$ and $\mathrm{Pd}-\mathrm{Cu}$ alloy membranes exposed to $\mathrm{H}_{2} \mathrm{~S}$ concentrations between 500 ppmv and 1000 ppmv [30] and $\mathrm{H}_{2}$ permeability loss for a $\mathrm{Pd}$ membrane exposed to 20 ppmv $\mathrm{H}_{2} \mathrm{~S}$ in $60 \% \mathrm{H}_{2}$ with $\mathrm{He}$ at $320{ }^{\circ} \mathrm{C}$ [31].

The ratio of $\mathrm{H}_{2} \mathrm{~S}$-to- $\mathrm{H}_{2}$ in these experiments with $\mathrm{H}_{2} \mathrm{~S}$ concentrations between 5 and $39 \mathrm{ppmv}$ in the feed was between $5.0 \times 10^{-6}$ and $3.9 \times 10^{-5}$. Considering the fact that the membranes separated $\mathrm{H}_{2}$ along the length of the separator, pushing the ratio of $\mathrm{H}_{2} \mathrm{~S}$-to- $\mathrm{H}_{2}$ higher toward to the end of the separator, the ratio of $\mathrm{H}_{2} \mathrm{~S}-$ to $-\mathrm{H}_{2}$ was calculated to be between $2.2 \times 10^{-5}$ and $6.5 \times 10^{-5}$ at the exit of the separator, depending on the $\mathrm{H}_{2}$ recovery. This ratio of $\mathrm{H}_{2} \mathrm{~S}-$ to- $-\mathrm{H}_{2}$ was below the threshold to form thermodynamically stable $\mathrm{Pd}_{4} \mathrm{~S}$ based on the literature work [15]. Destructive analysis of this $\mathrm{Pd}-\mathrm{Cu}$ separator was not conducted for sulfide formation on the membrane surface since the separator was still in operation. However, no sulfide formation was expected because the $\mathrm{H}_{2} \mathrm{~S}-$ to $-\mathrm{H}_{2}$ ratio was below the threshold necessary to form thermodynamically stable $\mathrm{Pd}_{4} \mathrm{~S}$.

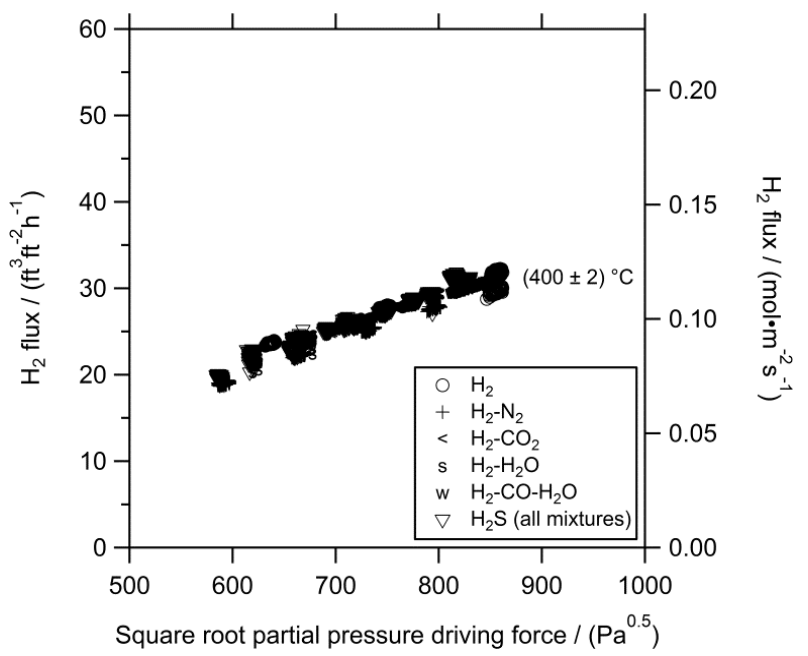

Figure 8: $\mathrm{H}_{2}$ flux versus $\mathrm{H}_{2}$ square root driving force for different gas mixtures at $400{ }^{\circ} \mathrm{C}$ with $\mathrm{H}_{2} \mathrm{~S}$ concentrations between 5 ppmv and 39 ppmv.

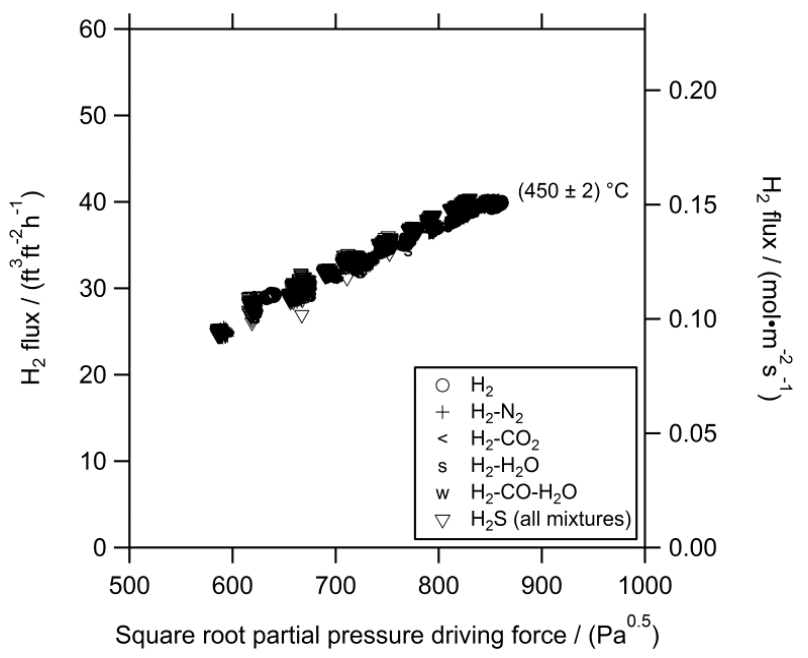

Figure 9: $\mathrm{H}_{2}$ flux versus $\mathrm{H}_{2}$ square root driving force for different gas mixtures at $450{ }^{\circ} \mathrm{C}$ with $\mathrm{H}_{2} \mathrm{~S}$ concentrations between 5 ppmv and 39 ppmv. 


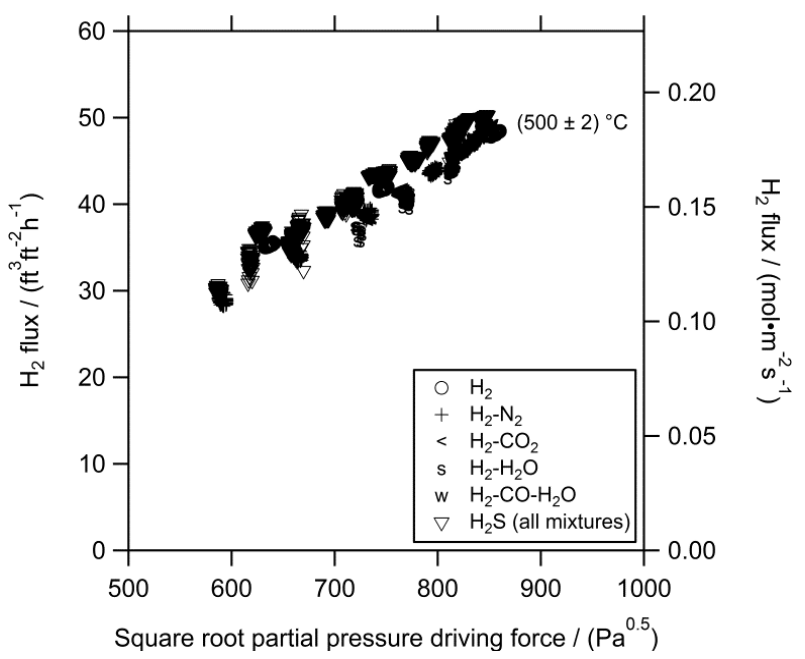

Figure 10: $\mathrm{H}_{2}$ flux versus $\mathrm{H}_{2}$ square root driving force for different gas mixtures at $500{ }^{\circ} \mathrm{C}$ with $\mathrm{H}_{2} \mathrm{~S}$ concentrations between 5 ppmv and 39 ppmv.

Figure 11 shows the $\mathrm{H}_{2}$ permeability durability with and without $\mathrm{H}_{2} \mathrm{~S}$ in pure $\mathrm{H}_{2}$ at $400{ }^{\circ} \mathrm{C}$, $450{ }^{\circ} \mathrm{C}$, and $500{ }^{\circ} \mathrm{C}$. It was very clear that the $\mathrm{H}_{2}$ permeability with and without $20 \mathrm{ppmv}_{2} \mathrm{~S}$ in the feed was identical at $500{ }^{\circ} \mathrm{C}$, further confirming that there was no $\mathrm{H}_{2} \mathrm{~S}$ inhibition on the $\mathrm{H}_{2}$ permeation of the $\mathrm{Pd}-\mathrm{Cu}$ alloy separator. The $\mathrm{H}_{2}$ permeability from pure $\mathrm{H}_{2}$ was a little higher than that with $20 \mathrm{ppmv}_{2} \mathrm{~S}$ at $450{ }^{\circ} \mathrm{C}$, but the $\mathrm{H}_{2}$ permeability with 20 ppmv $\mathrm{H}_{2} \mathrm{~S}$ was stabilized and reached the same level as that without $20 \mathrm{ppmv} \mathrm{H}_{2} \mathrm{~S}$. The experiments at $400{ }^{\circ} \mathrm{C}$ with 20 ppmv $\mathrm{H}_{2} \mathrm{~S}$ in the pure $\mathrm{H}_{2}$ feed were repeated twice at the beginning of the testing due to an unexpected rig shutdown. The $\mathrm{H}_{2}$ permeability showed a slight decline with time for the first and second tests, perhaps suggesting there might be very slight inhibition effect from $\mathrm{H}_{2} \mathrm{~S}$ possibly due to its adsorption on the $\mathrm{Pd}-\mathrm{Cu}$ alloy membrane surface. However, the $\mathrm{H}_{2}$ permeability on the third test was constant after the tests at $450{ }^{\circ} \mathrm{C}$ and $500{ }^{\circ} \mathrm{C}$ were completed, indicating there was no further adsorption. The $\mathrm{H}_{2} \mathrm{~S}$-to- $\mathrm{H}_{2}$ ratio was $2.0 \times 10^{-5}$ at the inlet and about $2.7 \times 10^{-5}$ at the exit due to the $\mathrm{H}_{2}$ permeation through the separator. The $\mathrm{H}_{2} \mathrm{~S}$-to- $\mathrm{H}_{2}$ ratio of $2.7 \times 10^{-5}$ at the outlet of the separator was below the threshold to form thermodynamically stable $\mathrm{Pd}_{4} \mathrm{~S}$, and thus no formation of sulfide on the membrane surface was expected. A final $\mathrm{N}_{2}$ leak check was performed to determine whether a leak developed after the Pd-Cu separator was tested for 1031 hours including 618 hours in the presence of $\mathrm{H}_{2} \mathrm{~S}$. No $\mathrm{N}_{2}$ leak was observed, indicating that the $\mathrm{Pd}-\mathrm{Cu}$ separators exhibited good thermal and structural stability.

Electron backscattered diffraction (EBSD) analysis of this type of dense $\mathrm{Pd}-\mathrm{Cu}$ alloy membrane showed that insignificant $\mathrm{Pd}-\mathrm{Cu}$ grain growth occurred during long-term operation. The grain size of the $\mathrm{Pd}-\mathrm{Cu}$ alloy membrane was about $58 \mu \mathrm{m}$ prior to testing and about $61 \mu \mathrm{m}$ post testing. In contrast, it was observed that the ideal $\mathrm{H}_{2} / \mathrm{He}$ selectivity for a $\mathrm{Pd}-\mathrm{Cu}$ deposited membrane declined to 512 from about 10,000 after testing at $450{ }^{\circ} \mathrm{C}$ for only 164 hours due to grain coarsening [12]. 


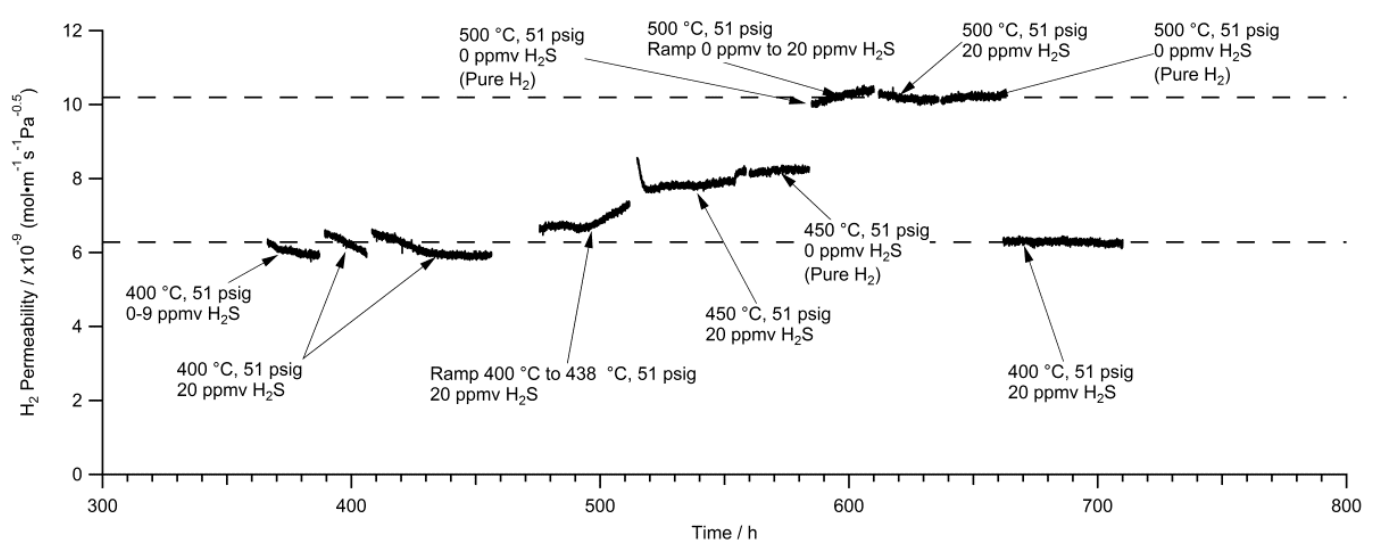

Figure 11: $\mathrm{H}_{2}$ permeability durability with and without presence of $\mathrm{H}_{2} \mathrm{~S}$ at different temperatures.

\subsection{Performance of Surface Modified Membranes versus Baseline}

By the end of September 2011, all but two of the separators (identified as 5295 and 5296) were evaluated for their hydrogen separation capability. Information about the separators' materials of construction, permeation area, and operating pressure limitation is given in Table 2. Three of the pilot-scale separators, identified as 5298, 5307, and 5312 were tested at EERC on coal gasifier exhaust with each membrane separating greater than $2 \mathrm{lb}_{\text {day }}{ }^{-1} \mathrm{H}_{2}$ (see Section 3.4). One of the project objectives was to compare the performance of a proprietary, surface modified, $\mathrm{Pd}-\mathrm{Cu}$ membrane to a conventional $\mathrm{Pd}-\mathrm{Cu}$.

An Arrhenius plot of the pure hydrogen permeability for the separators versus temperature is given in Figure 12. Also shown on the plot are the best curve fits to the experimental data with the corresponding 95\% confidence limits for both the fit coefficients and the fitting functions. The permeability data for the separators can be broken into three groups. The laboratory-scale separators (5276, 5277, 5290, and 5291) with the enhanced $\mathrm{Pd}-\mathrm{Cu}$ exhibited the highest permeability, although there was some variation in performance between the separators, particularly at higher temperatures. The next highest performing group was the larger pilot-scale separators with the enhanced $\mathrm{Pd}-\mathrm{Cu}$ tubes (separators 5307, 5312, 5313, and 5314). The tubes in those separators were made by a proprietary scaled-up production method, but whether the manufacturing scale contributed to the performance gap between the laboratory-scale and pilotscale separators is not known. The lowest permeability membranes were the two pilot-scale separators made without the enhanced $\mathrm{Pd}-\mathrm{Cu}$ (separators 5297 and 5298) which exhibited the typical performance for the conventional $\mathrm{Pd}-\mathrm{Cu}$ alloy.

Based on the data accumulated so far, the enhanced $\mathrm{Pd}-\mathrm{Cu}$ membranes have a measureable increased hydrogen permeability over conventional $\mathrm{Pd}-\mathrm{Cu}$ with the same composition. This increase is more pronounced at lower temperatures. For example, at $500{ }^{\circ} \mathrm{C}$, the permeability of the laboratory-scale enhanced $\mathrm{Pd}-\mathrm{Cu}$ separators was $26.3 \%$ higher than the uncoated $\mathrm{Pd}-\mathrm{Cu}$ separators and the coated pilot-scale separators were $9.7 \%$ higher. In comparison, at $400{ }^{\circ} \mathrm{C}$, those increased permeability percentages were $51.2 \%$ and $19.3 \%$, respectively. 


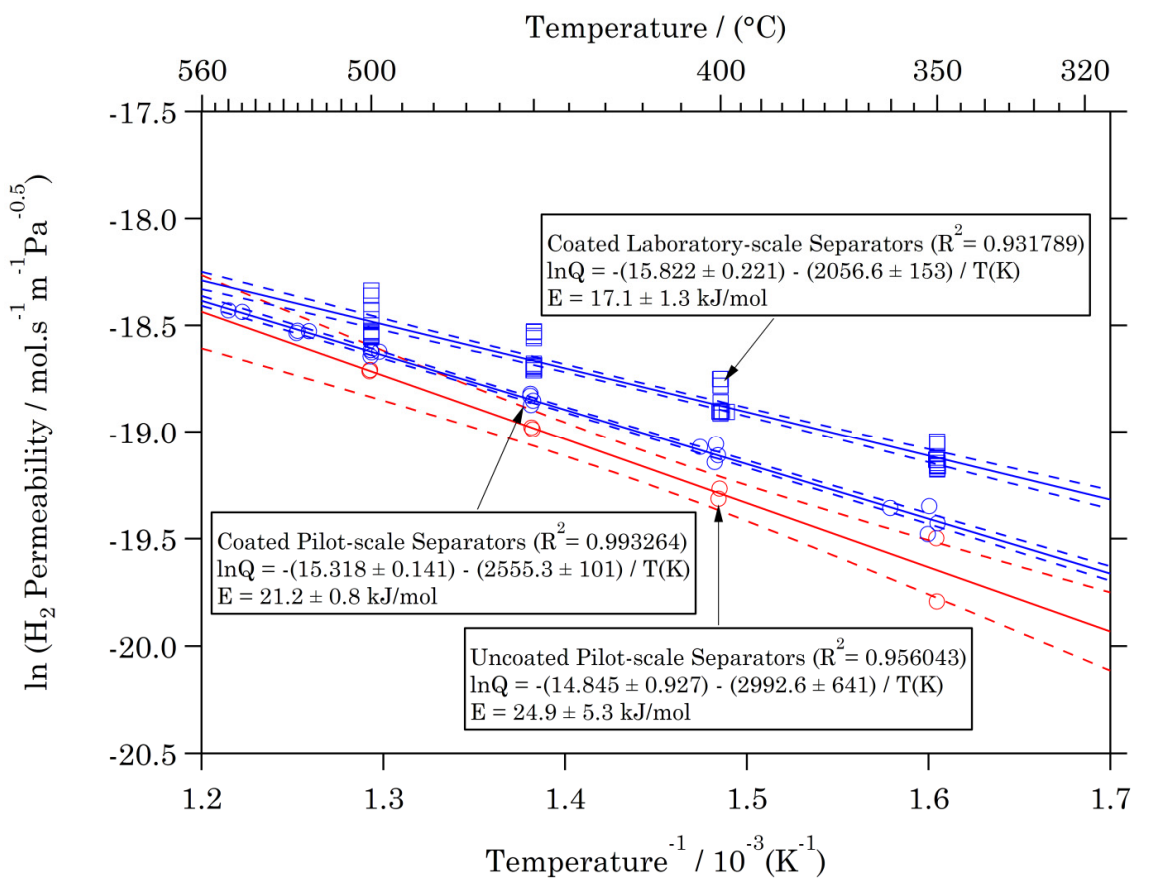

Figure 12: Arrhenius plot of the pure hydrogen permeability versus temperature for the Pd-Cu separators tested through September 2011. Shown are the best curve fits and $95 \%$ confidence limits for the enhanced (coated) Pd-Cu laboratory-scale separators, enhanced $\mathrm{Pd}-\mathrm{Cu}$ pilot-scale separators, and the uncoated $\mathrm{Pd}-\mathrm{Cu}$ pilot-scale separators.

\subsection{Effect of Syngas Species and $\mathrm{H}_{2} \mathrm{~S}$ on Membrane Durability}

\subsubsection{Separator 5290 Durability Testing (Mechanical Tube Failure)}

Separator 5290 is a laboratory-scale membrane separator that was constructed primarily out of C-276 based on the initial round of corrosion tests (see Section 3.5). However, two small internal components were still made out of SS-316. Separator 5290 was selected for a 500 hour durability test in the presence of $>20$ ppmv $\mathrm{H}_{2} \mathrm{~S}$ under DOE test 2 a protocols to examine both the impact of sulfur testing on the separator internals as well as establish the time it takes for a separator to respond to sulfur addition. The original plan was to test the separator for $500 \mathrm{~h}$ and then disassemble the separator to characterize the materials of construction.

Figure 13 shows the total testing performed on separator 5290 including both the initial permeability tests and the durability data. Separator 5290 was tested for a total of 976 hours, including 510 hours of $\mathrm{H}_{2} \mathrm{~S}$ exposure with no signs of degradation at $500{ }^{\circ} \mathrm{C}$. Out of the total testing time, approximately $700 \mathrm{~h}$ was spent at the DOE test $1 / 2$ a conditions $\left(50 \% \mathrm{H}_{2}, 30 \% \mathrm{CO}_{2}\right.$, $19 \% \mathrm{H}_{2} \mathrm{O}, \& 1 \% \mathrm{CO}$ ). The major impact on observed hydrogen flux was the partial pressure of hydrogen, with an approximately 50\% decrease in hydrogen flux with the switch from $100 \% \mathrm{H}_{2}$ to the DOE test conditions $\left(50 \% \mathrm{H}_{2}\right)$. During the last few hours of the testing, the separator developed a leak in a single membrane tube. The separator was subsequently disassembled for post-test characterization to determine the root cause of the failure. 


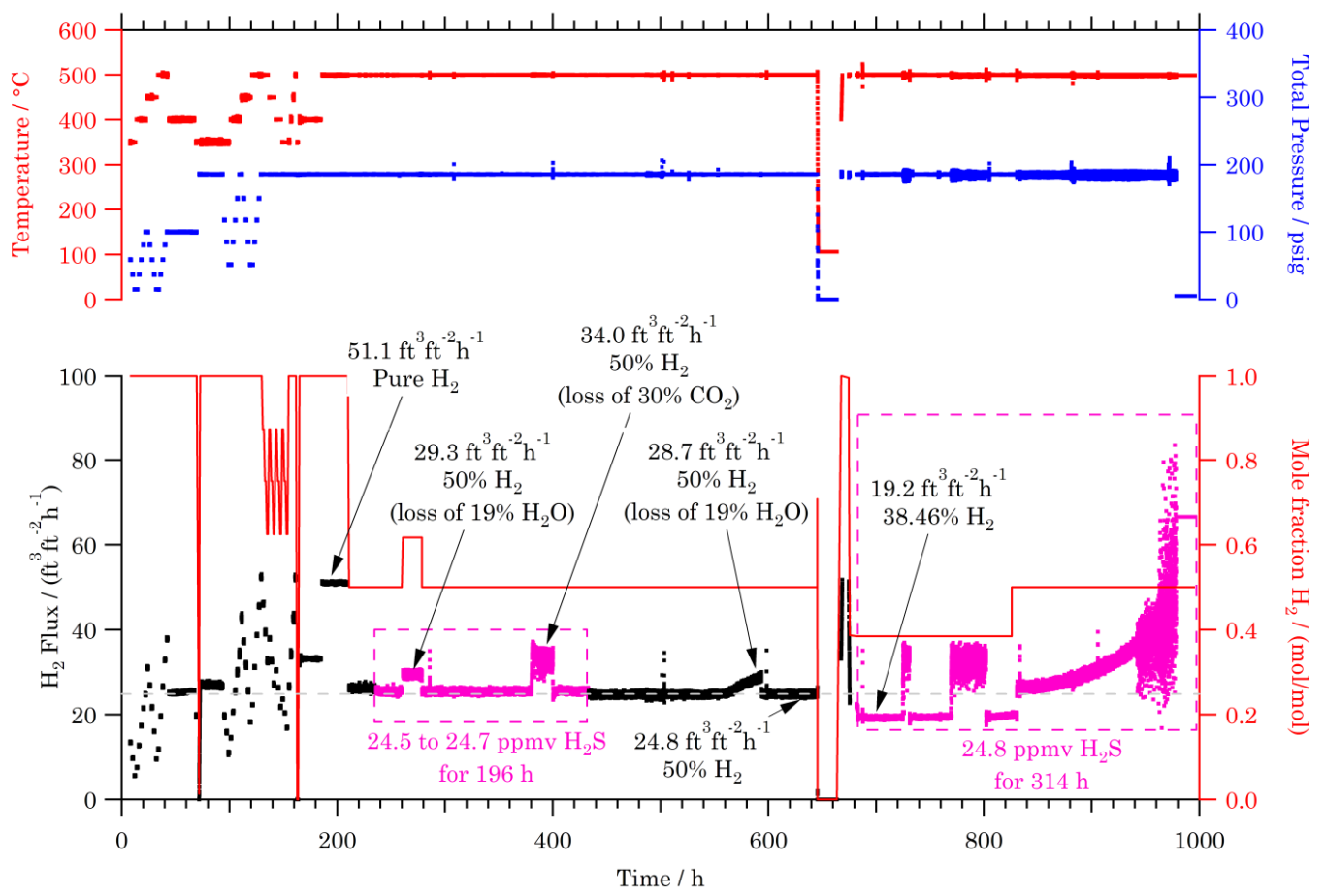

Figure 13: Performance and durability testing of laboratory-scale separator 5290.

Plan view and cross-section SEM analysis showed no sign of sulfur attack or chemical contamination in the leak site. In addition, the fracture surface did not appear to exhibit evidence of fatigue as can be seen in Figure 14. Electron backscattered diffraction (EBSD) data taken of the leak site polished in cross-section suggested that the failure occurred at a grain boundary.

Additional chemical analysis data was taken from membrane tubes sectioned toward the gas inlet side of the separator, the middle of the separator, and the outlet side of the separator as shown in Figure 15 below. Similar analyses run on separators that do show evidence of sulfur attack tend to show concentrated sulfide formation toward the outlet side of the membrane. This is easily explained by the higher $\mathrm{H}_{2} \mathrm{~S}$ partial pressure experienced at the end of the separator once a large portion of the $\mathrm{H}_{2}$ in the gas stream has been separated out.

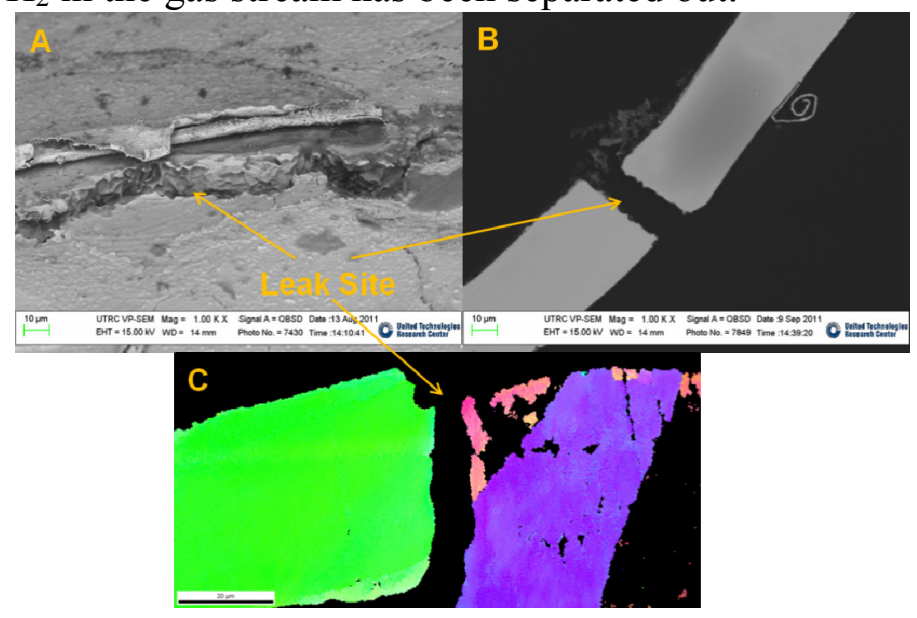

Figure 14: Plan view (A) and cross-section (B) SEM images of the membrane leak found in separator 5290. EBSD inverse pole figure (C) shows that the leak occurred at a grain boundary. 


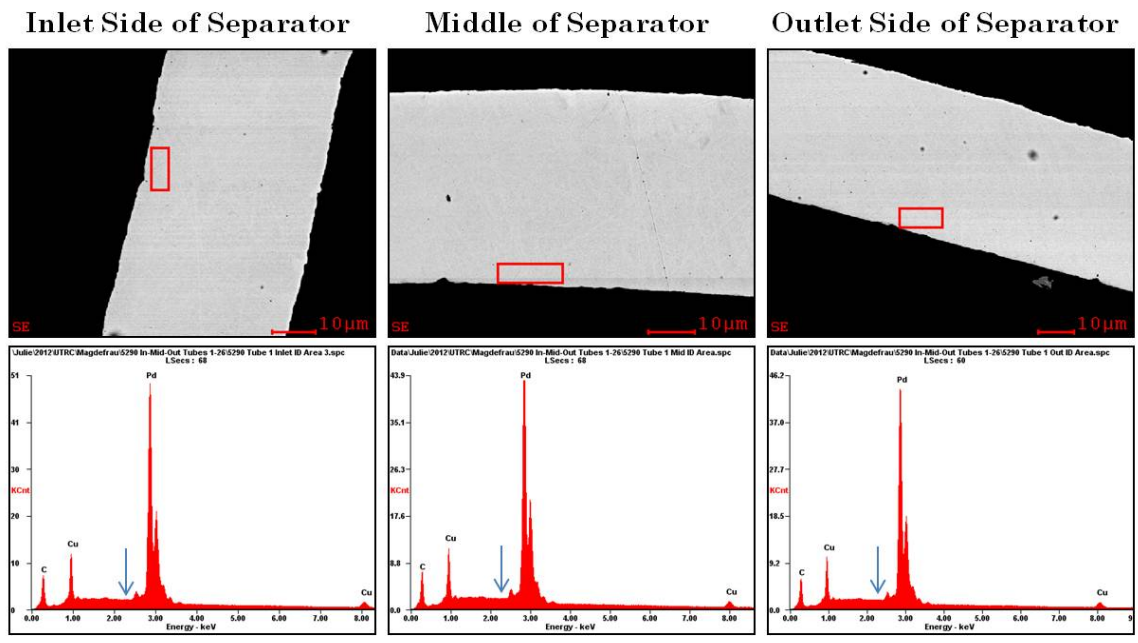

Figure 15: Cross-section EDS analysis of the ID of the membrane tube sectioned at the inlet, middle and outlet of the separator shows no evidence of sulfur attack on separator 5290. The sulfur K- $\alpha$ peak would sit at $2.31 \mathrm{keV}$ (see arrows) if present in the spectra above.

In an attempt to understand the failure mode of separator 5290, tensile tests were performed on these separator tubes and compared to both as-received $\mathrm{Pd}-\mathrm{Cu}$ separator tubes and 5297 separator tubes which did show evidence of sulfur attack. Separator 5297 is a pilot-scale separator that was tested with pure $\mathrm{H}_{2}$ and $\mathrm{H}_{2} / \mathrm{N}_{2}$ mixtures at feed pressures of 44.1 psia and 88.2 psia, respectively, to verify separator performance with UTRC's separator model. The separator was also tested with $\mathrm{H}_{2} \mathrm{~S}$ in $\mathrm{H}_{2}$ to verify its ability to withstand gasifier poisons. The maximum $\mathrm{H}_{2} \mathrm{~S}$ concentration used was 963 ppmv at 44.1 psia, approximately five times the maximum concentration of sulfur used for testing separator 5276. At $500{ }^{\circ} \mathrm{C}$, the reduction in $\mathrm{H}_{2}$ permeation from the 0.043 psia $\mathrm{H}_{2} \mathrm{~S}$ was approximately $50 \%$ but the $\mathrm{H}_{2}$ performance recovered fully after exposure to pure $\mathrm{H}_{2}$. Separator 5297 was also pressure checked at 400 psia and found to be leak free. The separator was exposed to four thermal cycles in $\mathrm{H}_{2} / \mathrm{N}_{2}$ from $200{ }^{\circ} \mathrm{C}$ to $500{ }^{\circ} \mathrm{C}$ with no performance degradation and no leaks. Separator 5297 was shipped to EERC after a total of 356 hours of testing at UTRC to serve as the test article for a coal gasifier test before the end of September. However, Separator 5297 failed at UND-EERC while holding under pressure in $\mathrm{N}_{2}$. The separator was shipped back to UTRC for post-test analysis which revealed a tube failure.

The room temperature tensile strength data are shown in Table 4. Tubes taken from Separator 5290 showed a 30\% reduction in the ultimate tensile strength when compared to new, asreceived tubes, and to tubes from Separator 5297. The data suggested that poor mechanical properties of the tubes in Separator 5290 were responsible for the failure which was further verified during tube burst testing (see Section 3.3.3). 
Table 4: Room temperature tensile test data taken from an average of 3 samples for each condition. Note that separator tubes from 5290 showed a 30\% reduction in strength in comparison to all other membrane tubes tested.

\begin{tabular}{lc}
\hline Sample ID & Ultimate Tensile Strength (psi) at Room Temperature \\
\hline New Tubes & 99244.5 \\
Separator 5290 & 69843.6 \\
Separator 5297 Inlet & 98527.7 \\
Separator 5297 Middle & 95874.8 \\
Separator 5297 Outlet & 101225.7 \\
\hline
\end{tabular}

\subsubsection{Separator 5313 Durability Testing (Sulfidation Failure)}

Separator 5313 was a pilot-scale $\left(\approx 1.5 \mathrm{ft}^{2}\right)$ separator that was used for a long-term durability test. The durability test began on 8 November 2011 to demonstrate the separation of $2 \mathrm{lb}$ day $^{-1} \mathrm{H}_{2}$ with $\geq 95 \%$ recovery under the DOE testing protocol conditions. To achieve this very high $\mathrm{H}_{2}$ recovery, a heated $\mathrm{N}_{2}$ sweep gas system on the permeate side of the membrane was installed and a new approach to measuring the outlet $\mathrm{H}_{2}$ flow rate was developed.

At the beginning of December 2011, the durability test had passed 549 hours of operation with stable membrane performance at $1.97 \pm 0.36 \mathrm{lb}_{\text {day }}{ }^{-1} \mathrm{H}_{2}$ and $(87.0 \pm 15.7) \%$ recovery, demonstrating the target performance metrics for the project. Figure 16 shows all of the testing data for Separator 5313, including previous $\mathrm{H}_{2}$ permeation experiments performed prior to the durability run. The higher gas feed flow rates required for this higher recovery, coupled with the need for a larger condensate reservoir for the retentate stream, resulted in difficulties for the back pressure regulator to control the pressure, and thus the temperature, of the separator. The 5\% variation in temperature and pressure translated into up to $20 \%$ errors in the flux measurements. A smoothed flux curve is also displayed in the Figure to show the data more clearly.

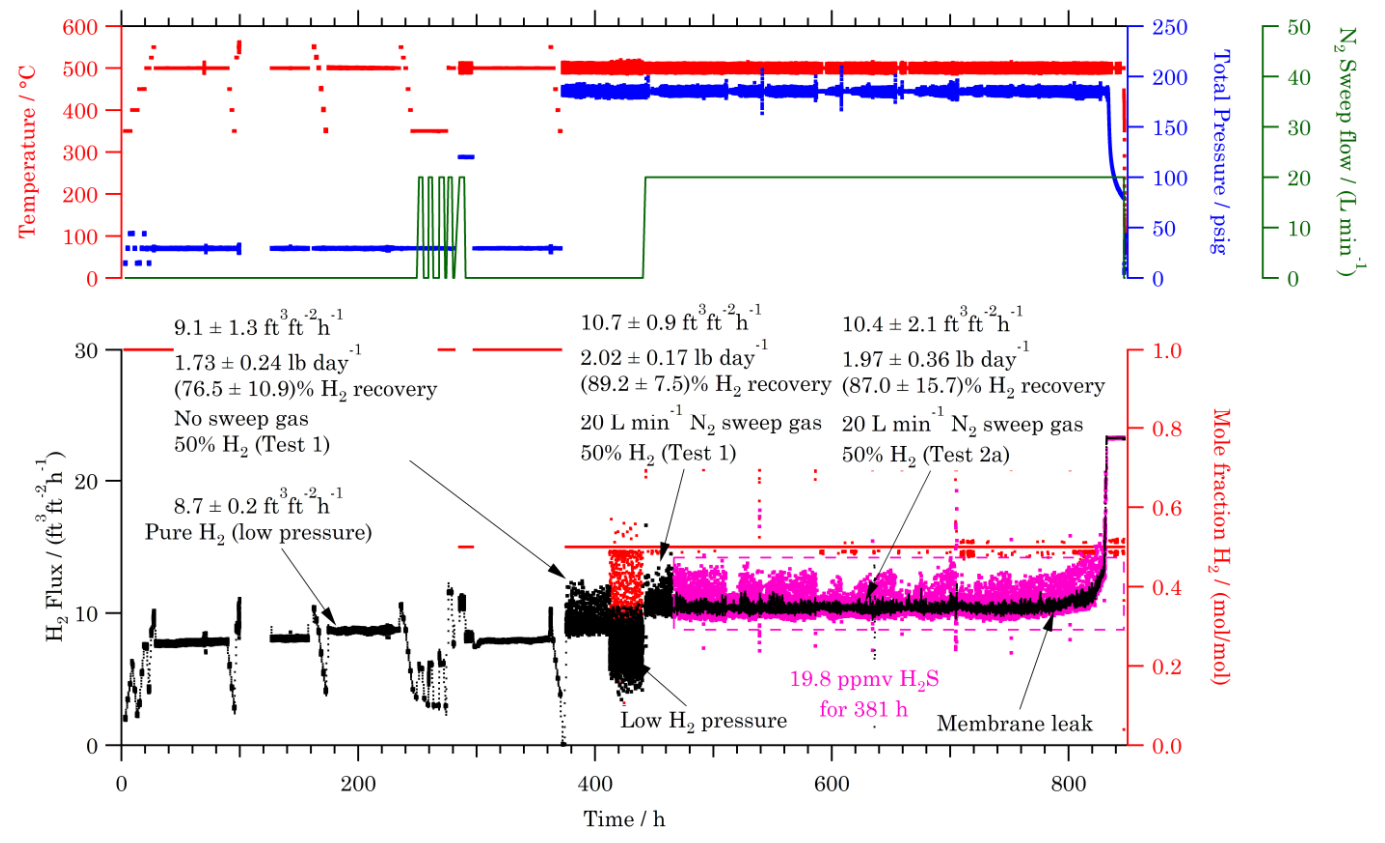

Figure 16: Performance and durability testing of laboratory-scale separator 5313. 
The baseline flux in pure $\mathrm{H}_{2}$ at a total pressure of 44.09 psia was $8.7 \pm 0.2 \mathrm{ft}^{3} \mathrm{ft}^{-2} \mathrm{~h}^{-1}$. The durability test was broken into three phases. The first step evaluated the membrane performance under the DOE Test 1 conditions $\left(50 \% \mathrm{H}_{2}\right)$, without sweep gas on the permeate side of the membrane. At 200 psia, the membrane separated $1.73 \pm 0.24 \mathrm{lb}_{\text {day }}{ }^{-1} \mathrm{H}_{2}\left(9.1 \pm 1.3 \mathrm{ft}^{3} \mathrm{ft}^{-2} \mathrm{~h}^{-1}\right)$ with a recovery of $(76.5 \pm 10.9) \%$, which was lower than expected and equivalent to a $65 \%$ reduction in $\mathrm{H}_{2}$ permeability.

After a brief period where the $\mathrm{H}_{2}$ feed compressor was not able to deliver high enough $\mathrm{H}_{2}$ pressure, the second phase of the durability test was started. In this second step, $20 \mathrm{~L} \mathrm{~min}^{-1}$ of nitrogen was flowed through the permeate side of the separator to increase the separation driving force and increase the flux. The membrane then separated $2.02 \pm 0.17 \mathrm{lb} \mathrm{day}^{-1} \mathrm{H}_{2}$ $\left(10.7 \pm 0.9 \mathrm{ft}^{3} \mathrm{ft}^{-2} \mathrm{~h}^{-1}\right)$ with a recovery of $(89.2 \pm 7.5) \%$. This was again a lower performance than expected. The addition of such a large flow of sweep gas resulted in an increase in back pressure on the permeate side of the membrane. However, after correcting for this effect, the separator performed equivalent to a $55 \%$ reduction in $\mathrm{H}_{2}$ permeability.

The third phase of testing moved to the DOE Test $2 \mathrm{a}$ conditions by adding $19.8 \mathrm{ppmv} \mathrm{H}_{2} \mathrm{~S}$ to the feed while the $\mathrm{N}_{2}$ sweep gas remained at $20 \mathrm{~L} \mathrm{~min}^{-1}$. The addition of the sulfur resulted in no significant change to the separator performance, with the membrane separating $1.97 \pm 0.36 \mathrm{lb} \mathrm{day}^{-1} \mathrm{H}_{2}\left(10.4 \pm 2.1 \mathrm{ft}^{3} \mathrm{ft}^{-2} \mathrm{~h}^{-1}\right)$ with a recovery of $(87.0 \pm 15.7) \%$. This was still equivalent to a $55 \%$ reduction in $\mathrm{H}_{2}$ permeability after accounting for the increased permeate back pressure due to the high sweep gas flow.

After a total testing time of 847 hours, including 381 hours in the presence of sulfur, the membrane developed a leak. For comparison, a smaller separator (5290), which also developed a leak in 2011, had been tested for a total of 976 hours with 510 hours in the presence of sulfur before it failed (see Section 3.3.1). As in the case of separator 5290, tube failure was responsible for the leak. The separator was leak checked using a bubble test in isopropanol and found to have two tubes with small leaks, each of which were located approximately 0.5 inches from the tube end cap. Figure 17 shows an electron image of the largest leak site.

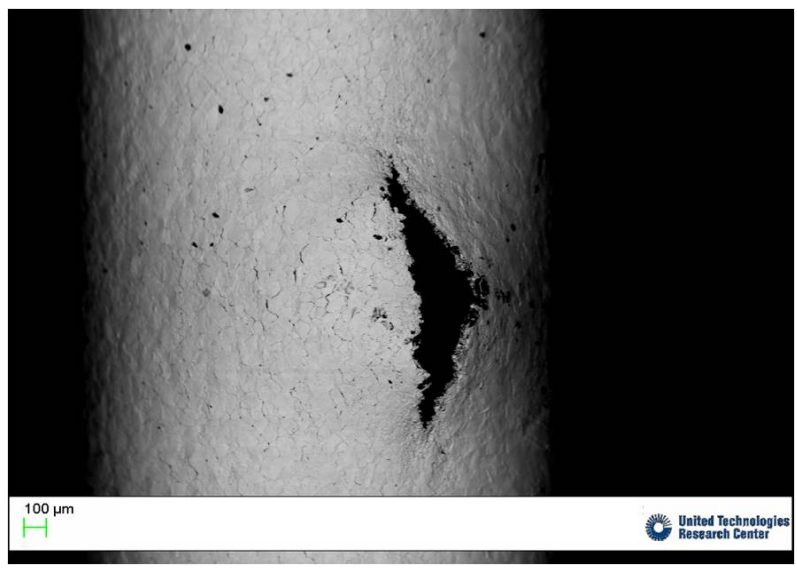

Figure 17: A backscattered electron image showing one of the leak sites on separator 5313.

Inlet, middle, and outlet portions of representative membrane tubes from 5313 were mounted in cross-section and analyzed as had been done on previous separators. While a continuous sulfide layer was formed on the outlet portion of the separator, as shown in Figure 18, there was no sign of sulfur attack on the inlet portion of the separator. This further illustrates the fact that when running the separator at high $\mathrm{H}_{2}$ recovery conditions, one can expect a higher $\mathrm{H}_{2} \mathrm{~S} / \mathrm{H}_{2}$ 
partial pressure ratio on the outlet portion of the separator which can lead to sulfur attack even at a low $\mathrm{H}_{2} \mathrm{~S}$ feed concentration. This is a particularly important finding as future separators for high $\mathrm{H}_{2}$ recovery applications will need to be designed and operated so that the outlet portion of the $\mathrm{Pd}$ membranes are below the critical $\mathrm{H}_{2} \mathrm{~S} / \mathrm{H}_{2}$ value for the formation of $\mathrm{Pd}_{4} \mathrm{~S}$.

In the case of separator 5290, the tube failure was due to a grain boundary failure across a single large grain that ran the entire thickness of the alloy tube wall. Tensile strength experiments had confirmed that the tubes were weaker than those in other separators, suggesting that mechanical properties were responsible for the failure. However, separator 5313 failed due to sulfur attack as noted by the presence of large $\mathrm{Pd}_{4} \mathrm{~S}$ phases in the alloy tubes.

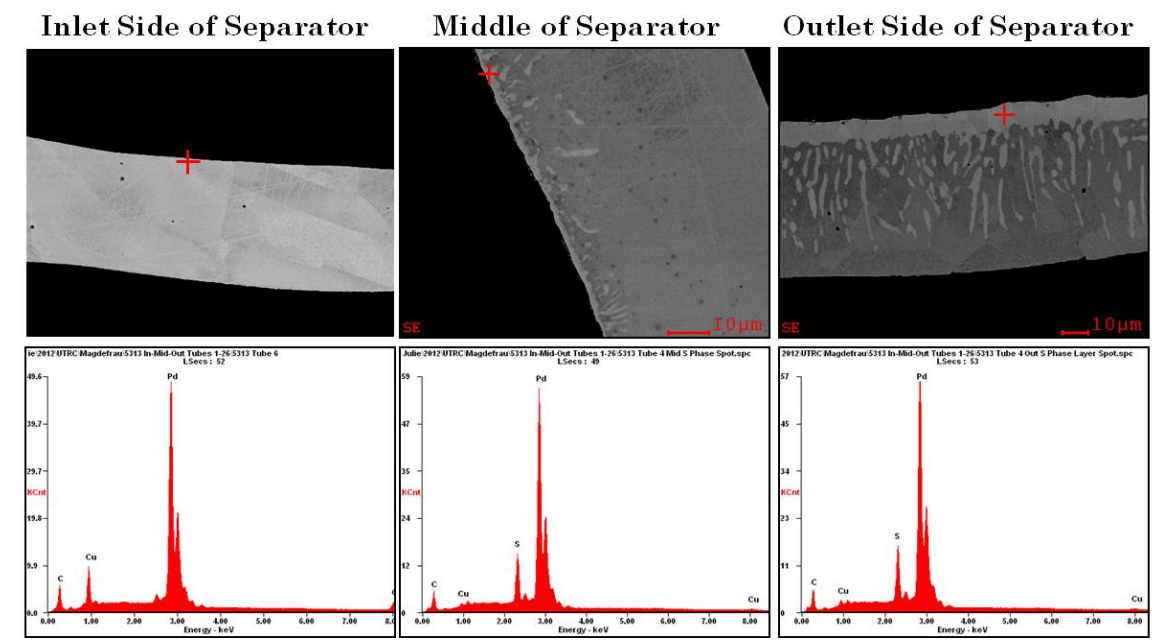

Figure 18: EDS analysis of inlet, middle and outlet tubes from separator 5313 show no sulfur attack on the inlet portion of the separator. Heavy sulfur attack is observed at the outlet end of the membrane as a continuous $\mathrm{Pd}_{4} \mathrm{~S}$ phase.

\subsubsection{Burst Testing of Separator Tubes}

A burst pressure rig was designed and built at UTRC in order to test the mechanical properties of $\mathrm{Pd}-\mathrm{Cu}$ tubes. This rig enabled testing of single separator tubes both at high temperature and high pressure. Samples of separator tubes from separators were pressurized until failure at temperatures ranging from $25^{\circ} \mathrm{C}$ to $700{ }^{\circ} \mathrm{C}$. Figure 19 shows burst pressure data for three separators: 5290, which appeared to fail during testing due to poor mechanical strength; 5298, which had never failed during testing; and 5313, which failed due to sulfur attack. The separator membranes showed a decrease in burst strength with increasing temperature consistent with creep of $\mathrm{Pd}-\mathrm{Cu}$ at elevated temperatures. Separator 5313 showed a much higher degradation in comparison to Separator 5298. This was likely due to the increased sulfur attack observed in 5313 which resulted in dramatically lower burst strengths, especially at elevated temperatures. Samples from separator 5290 tested at $500{ }^{\circ} \mathrm{C}$ exhibited even lower burst strengths, confirming the tensile strength measurement data and conclusions regarding tube lower mechanical strength. 


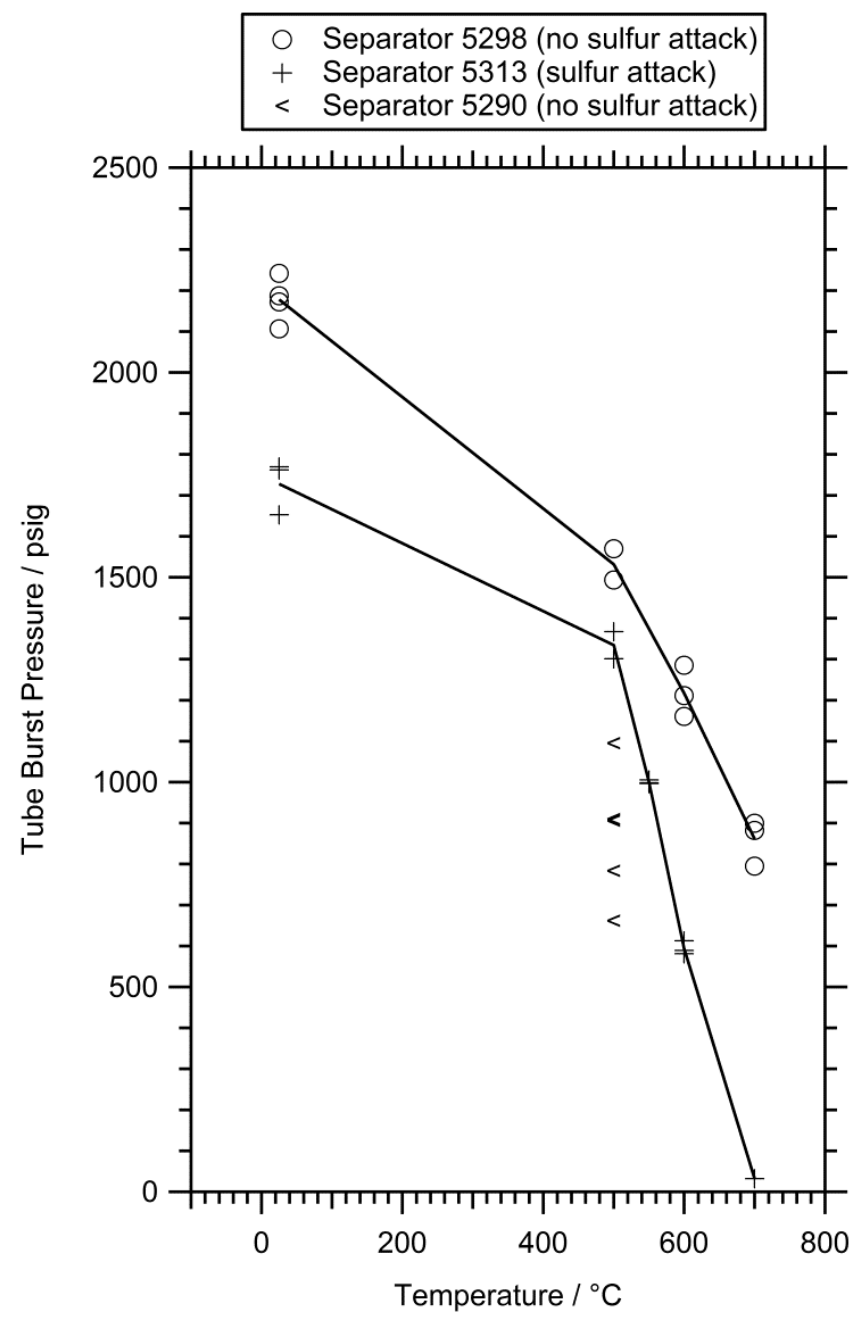

Figure 19: Comparison of tube burst pressure versus temperature for separators 5290, 5298, and 5313.

\subsubsection{Irreversible Sulfidation of Pd-Cu Membranes (Modeling \& Characterization)}

Separator 5313 was tested at the DOE Test 2a conditions, which included the presence of $19.8 \mathrm{ppmv}_{2} \mathrm{~S}$. In previous experiments at UTRC, this sulfur concentration did not result in sulfidation of the $\mathrm{Pd}-\mathrm{Cu}$ alloy or failure of the membrane. However, the flow rates and other operating conditions for the separator 5313 test were designed to maximize $\mathrm{H}_{2}$ recovery beyond levels that had ever been tested at UTRC. One possible hypothesis to explain the sulfur failure was that the $\mathrm{H}_{2} \mathrm{~S}$ concentration was actually very high in the part of the separator where the $\mathrm{H}_{2}$ concentration was low (i.e., a high ratio of $\mathrm{H}_{2} \mathrm{~S}$ to $\mathrm{H}_{2}$ ), resulting in a thermodynamic driving force to segregate $\mathrm{Pd}$ in the alloy and form $\mathrm{Pd}_{4} \mathrm{~S}$.

Iyoha et al. [15] had previously suggested that sulfur attack of $\mathrm{Pd}$ and $\mathrm{Pd}-\mathrm{Cu}$ alloys was due to a thermodynamic driving force to form $\mathrm{Pd}_{4} \mathrm{~S}$. In their analysis, the driving force for the formation of $\mathrm{Pd}_{4} \mathrm{~S}$ was the ratio of $\mathrm{H}_{2} \mathrm{~S}$ to $\mathrm{H}_{2}$ exposed to the alloy surface. Figure 20 reproduces the $\mathrm{Pd}_{4} \mathrm{~S}$ stability curve from the paper for a $\mathrm{Pd}_{0.7} \mathrm{Cu}_{0.3}$ alloy. A similar, lower value curve was also given in the reference for pure Pd. 


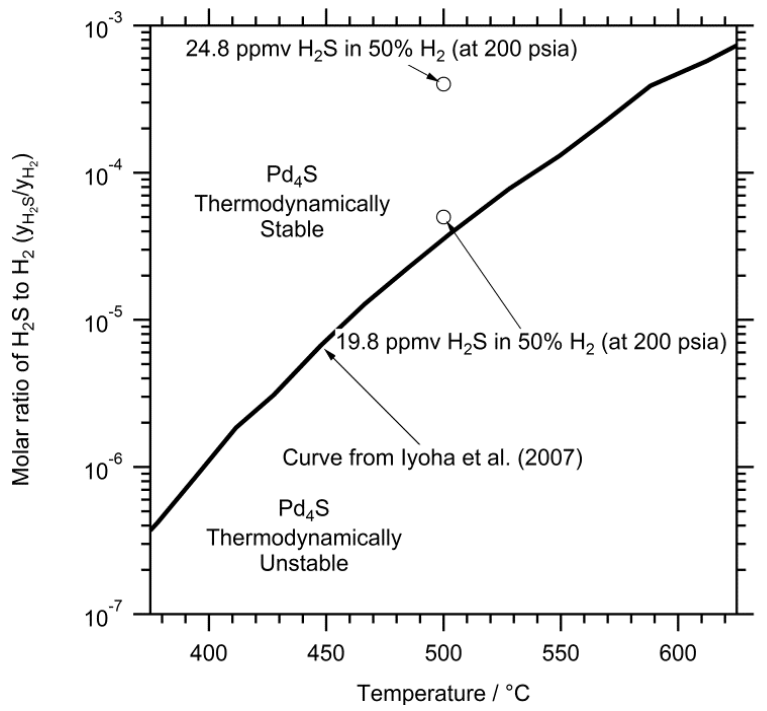

Figure 20: Thermodynamic limit for $\mathrm{Pd}_{4} \mathrm{~S}$ formation as a function of temperature for a $\mathrm{Pd}_{0.7} \mathrm{Cu}_{0.3}$ alloy [15].

Also shown in Figure 20 are the starting sulfur concentrations for the DOE Test 1 conditions when sulfur was added (Test 2a) for separators 5290 and 5313. Both inlet concentrations are above the thermodynamic stability limit for $\mathrm{Pd}_{4} \mathrm{~S}$ and thus should result in sulfur attack. However, separator 5290, which started with a higher sulfur concentration, did not show any evidence of sulfur attack, while separator 5313 showed heavy sulfur attack toward the end of the separator.

In order to aid in the understanding of the critical $\mathrm{H}_{2} \mathrm{~S} / \mathrm{H}_{2}$ ratio for sulfide formation, a representative tube from 5313 was evenly sectioned and each section was mounted, polished, and examined using SEM/EDS. The results are shown below in Figure 21 in which it can be seen that $\mathrm{Pd}_{4} \mathrm{~S}$ formation becomes noticeable in the SEM at $\mathrm{x} / \mathrm{L}=0.36$. Continuing further toward the outlet (i.e., $\mathrm{x} / \mathrm{L}=1$ ) portion of the tube, the formation of a continuous $\mathrm{Pd}_{4} \mathrm{~S}$ phase was detected. This phase was thought to be brittle and thus harmful to the overall strength of the membrane. Note the cracks within the sulfide layer that were observed at $\mathrm{x} / \mathrm{L}=0.68$.

The UTRC mathematical model describing separator performance was used to predict the performance of separators 5290 and 5313 neglecting the use of the sweep gas for separator 5313 . The results of the modeling at $500{ }^{\circ} \mathrm{C}$ and 200 psia are shown in Figure 22. Both the flux and recoveries at the end of the separator match the experimental results for both separators and thus account for the differences in membrane area and thicknesses between the separators.

In the case of separator 5290, the $\mathrm{H}_{2}$ recovery was relatively low, only $31.9 \%$, which resulted in the $\mathrm{H}_{2} \mathrm{~S}$ concentration to increase from $24.8 \mathrm{ppmv}$ to only $29.5 \mathrm{ppmv}$ by the end of the separator. This was in contrast to separator 5313, which had a very high recovery of $88.9 \%$, causing the inlet $\mathrm{H}_{2} \mathrm{~S}$ concentration of $19.8 \mathrm{ppmv}$ to increase to $35.7 \mathrm{ppmv}$ at the end of the separator.

Although the increase in $\mathrm{H}_{2} \mathrm{~S}$ concentration in separator 5313 was somewhat higher than separator 5290, the amount of $\mathrm{H}_{2}$ in the separator was decreasing significantly along the separator tubes due to the higher recovery. As a result, the ratio of $\mathrm{H}_{2} \mathrm{~S}$ to $\mathrm{H}_{2}$ in separator 5313 $\left(3.57 \times 10^{-4}\right)$ was almost five times higher than the ratio in separator $5290\left(7.29 \times 10^{-5}\right)$. In addition, the ratio in both separators was higher than the value reported in Iyoha at al. $\left(3.83 \times 10^{-5}\right)$ at $500{ }^{\circ} \mathrm{C}$. 


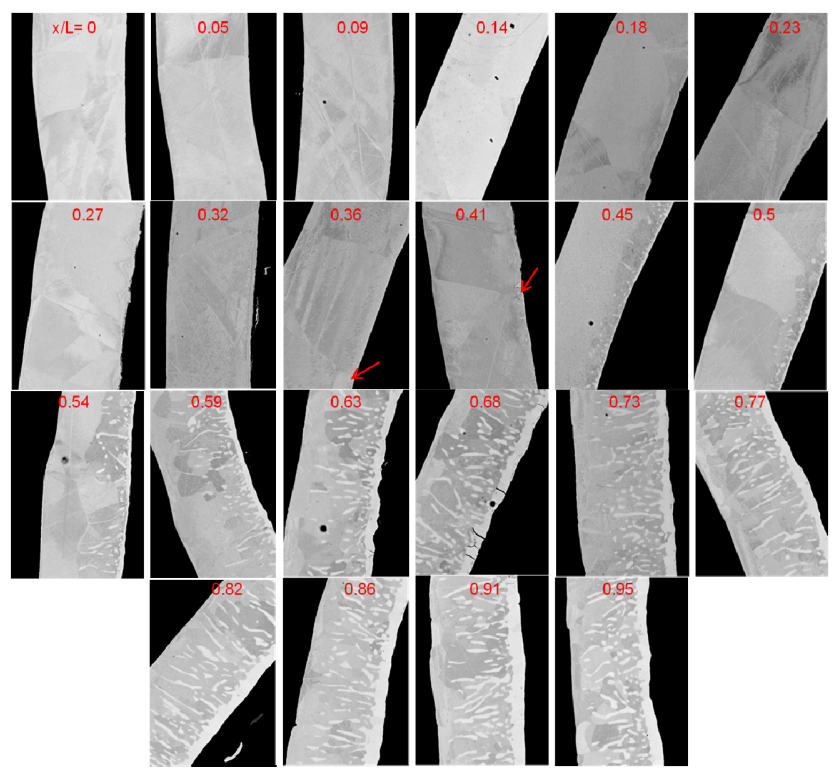

Figure 21: Backscattered electron images taken along the length of Separator 5313. $\mathrm{Pd}_{4} \mathrm{~S}$ formation appears to begin at $x / L=0.36$. At $x / L$ greater than 0.5 a continuous $P d_{4} S$ phase was present on the ID of the membrane tube.

The SEM/EDS information from the detailed sectioning of separator 5313 correlated very well with the $\mathrm{H}_{2} \mathrm{~S}$ to $\mathrm{H}_{2}$ ratio predicted from the model. The evidence based on the lack of sulfidation of separator 5290 set an $\mathrm{H}_{2} \mathrm{~S}$ to $\mathrm{H}_{2}$ ratio of $7.29 \times 10^{-5}$ as a conservative estimate for the $\mathrm{Pd}_{4} \mathrm{~S}$ thermodynamic limit for the UTRC Pd-Cu separators. This implied that the UTRC Pd$\mathrm{Cu}$ separators have approximately twice the sulfur resistance at $500{ }^{\circ} \mathrm{C}$ of the $\mathrm{Pd}_{0.7} \mathrm{Cu}_{0.3}$ alloy in

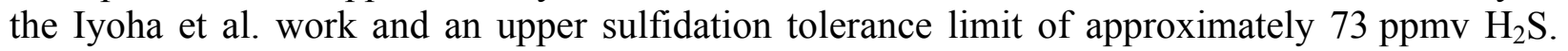
With that assumption, the model results for separator 5313 showed that no sulfur attack should occur within the first $30 \%(\mathrm{x} / \mathrm{L}=0$ to 0.33$)$ of the tube.

The model calculations as a function of relative membrane tube length showed that separator 5313 had an $\mathrm{H}_{2} \mathrm{~S}$ to $\mathrm{H}_{2}$ ratio of $7.24 \times 10^{-5}$ at $\mathrm{x} / \mathrm{L}=0.32$, which was below the value set by separator 5290, and thus consistent with the lack of $\mathrm{Pd}_{4} \mathrm{~S}$ formation in the section images up to $\mathrm{x} / \mathrm{L}=0.32$. The calculated $\mathrm{H}_{2} \mathrm{~S}$ to $\mathrm{H}_{2}$ ratio of $8.01 \times 10^{-5}$ at $\mathrm{x} / \mathrm{L}=0.36$ for separator 5313 was greater than the value of $7.29 \times 10^{-5}$ based on separator 5290 and consistent with the formation of $\mathrm{Pd}_{4} \mathrm{~S}$ shown at that location in Figure 21. Thus, the SEM/EDS analysis showed that the critical $\mathrm{H}_{2} \mathrm{~S}$ to $\mathrm{H}_{2}$ ratio for irreversible $\mathrm{Pd}_{4} \mathrm{~S}$ formation was between $7.24 \times 10^{-5}$ and $8.01 \times 10^{-5}$ for the UTRC separators and confirmed the hypothesis that the $\mathrm{H}_{2} \mathrm{~S}$ to $\mathrm{H}_{2}$ ratio in combination with the $\mathrm{H}_{2}$ recovery can explain separator failure due to sulfur attack.

The Separator $5290 \mathrm{H}_{2} \mathrm{~S} / \mathrm{H}_{2}$ limit can be used as a testing guideline until further data similar to the calculations shown in Figure 20 can be generated for the UTRC separators. Figure 23 plots the maximum allowable inlet $\mathrm{H}_{2} \mathrm{~S}$ concentration for UTRC separator testing versus the $\mathrm{H}_{2}$ concentration in the feed for different $\mathrm{H}_{2}$ recoveries. At relatively low recoveries (30\% or less) with a $50 \% \mathrm{H}_{2}$ feed gas, the UTRC separators should tolerate $\mathrm{H}_{2} \mathrm{~S}$ feed concentrations of $25 \mathrm{ppmv}$ indefinitely. However, at the DOE Test $2 \mathrm{a}$ objective conditions $\left(50 \% \mathrm{H}_{2}, 95 \%\right.$ recovery), the UTRC separators should not operate for long periods of time ( $>300 \mathrm{~h}$ based on testing times of failed membranes) above $2 \mathrm{ppmv}_{2} \mathrm{~S}$ to avoid irreversible sulfur attack failure. For $\mathrm{H}_{2}$ concentrations less than $20 \%$, the $5290 \mathrm{H}_{2} \mathrm{~S} / \mathrm{H}_{2}$ limit suggests that the sulfur feed levels 
DE-FE0004967

should be maintained below 10 ppmv $\mathrm{H}_{2} \mathrm{~S}$, depending on the recovery. All of these values may be a factor of 2 to 4 less for other Pd alloys.
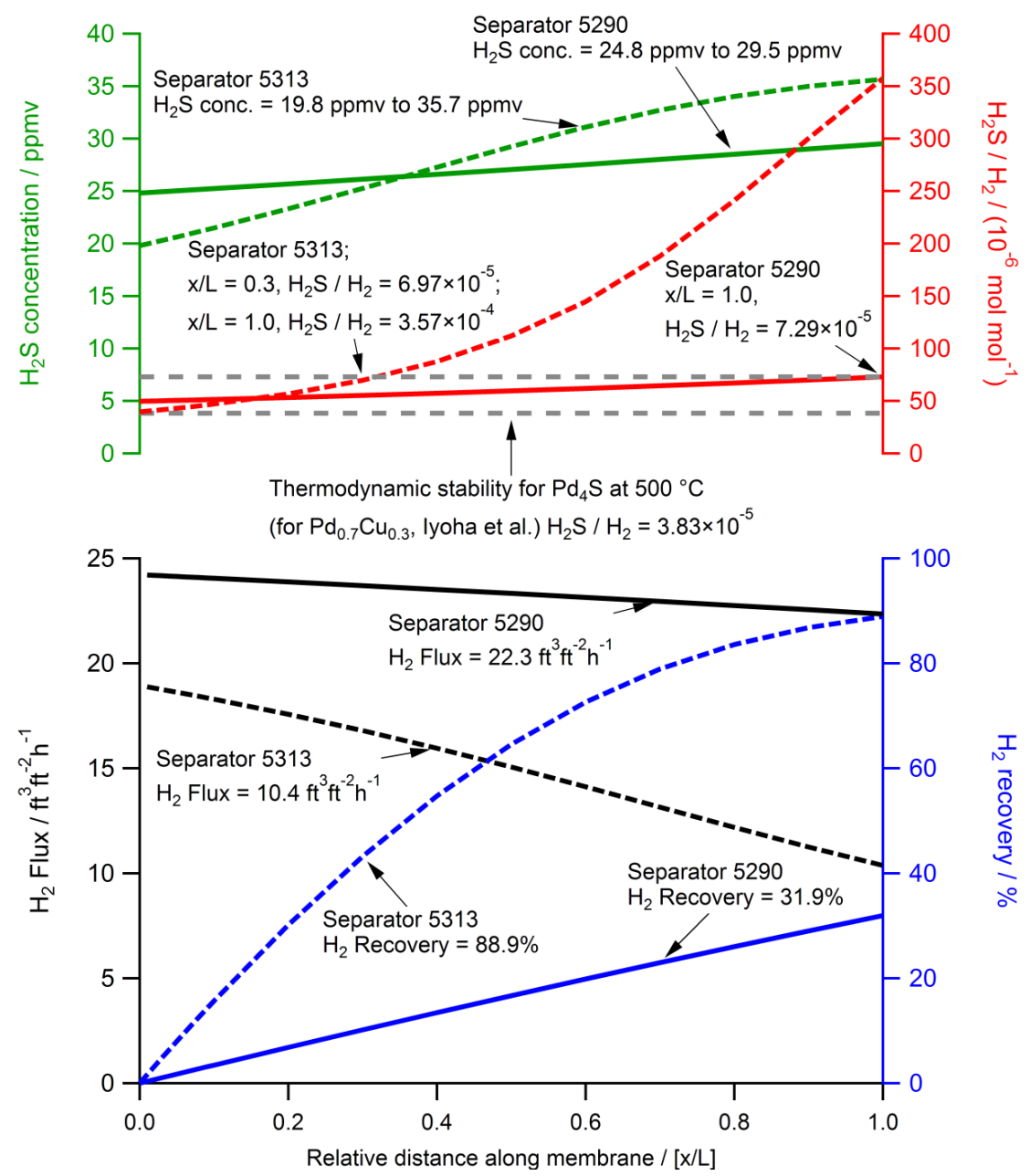

Figure 22: UTRC model simulations of separators 5313 and 5290 at $500{ }^{\circ} \mathrm{C}$ to compare the impact of $\mathrm{H}_{2}$ recovery on sulfur concentration in the membrane tubes.

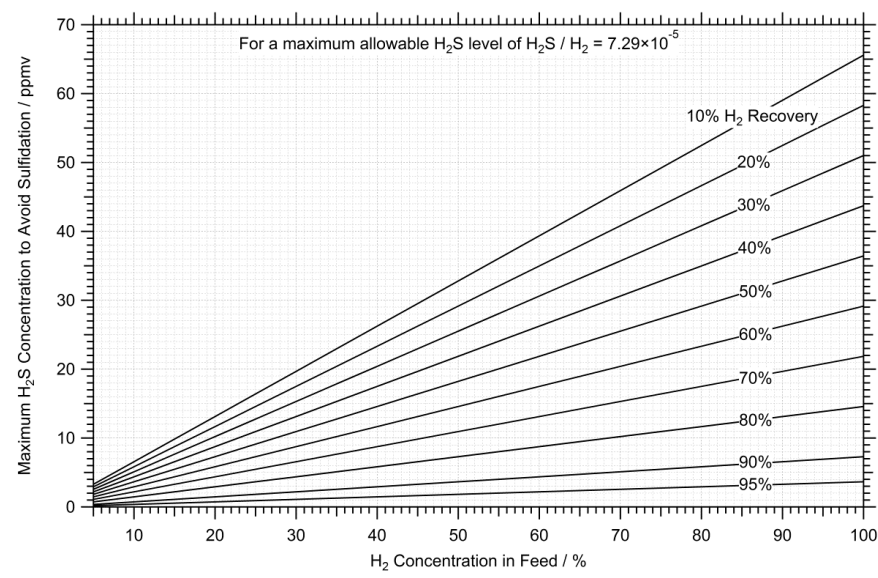

Figure 23: Maximum allowable sulfur level in feed gas at $500{ }^{\circ} \mathrm{C}$ based on separator 5290 resistance to sulfidation as a function of $\mathrm{H}_{2}$ feed concentration and $\mathrm{H}_{2}$ recovery. 


\subsubsection{Study of Impact of $\mathrm{H}_{2} \mathrm{~S}$ on Irreversible Sulfidation}

The effect of $\mathrm{H}_{2} \mathrm{~S}$ on the $\mathrm{Pd}-\mathrm{Cu}$ membrane was studied by subjecting small membrane coupons ( $1.2 \mathrm{~cm}$ to $2.5 \mathrm{~cm}$ in length) to ppmv level concentrations of $\mathrm{H}_{2} \mathrm{~S}$ at various temperatures in the experimental setup shown in Figure 24. In the first set of experiments, the bulk of the flow contacting the coupons was dry $\mathrm{H}_{2}$ and no $\mathrm{CO}_{2}, \mathrm{CO}$, or water vapor was present. The $\mathrm{H}_{2} \mathrm{~S}$ concentration was about 100 ppmv.

Table 5 gives a summary of the conditions for the first set of experiments, including the molar ratio of $\mathrm{H}_{2} \mathrm{~S}$ to $\mathrm{H}_{2}$. Iyoha et al. [15] presented a thermodynamic equilibrium line for the formation of $\mathrm{Pd}_{4} \mathrm{~S}$ in $\mathrm{Pd}-\mathrm{Cu}$ materials as a function of the $\mathrm{H}_{2} \mathrm{~S}$ to $\mathrm{H}_{2}$ molar ratio. The goal of the subscale experiments was to validate and establish a similar equilibrium line for the UTRC membrane material and determine the maximum $\mathrm{H}_{2} \mathrm{~S}$ concentration where the separators can be operated at as a function of temperature. Figure 25 shows the Iyoha line and the test points that were evaluated.

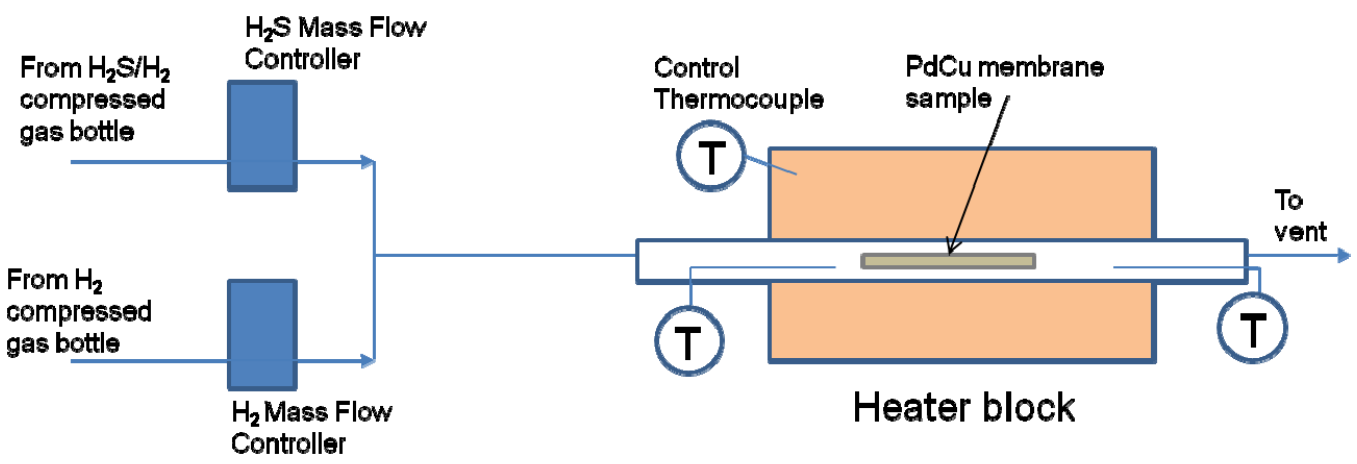

Figure 24: Flow schematic for membrane coupon sulfur exposure testing.

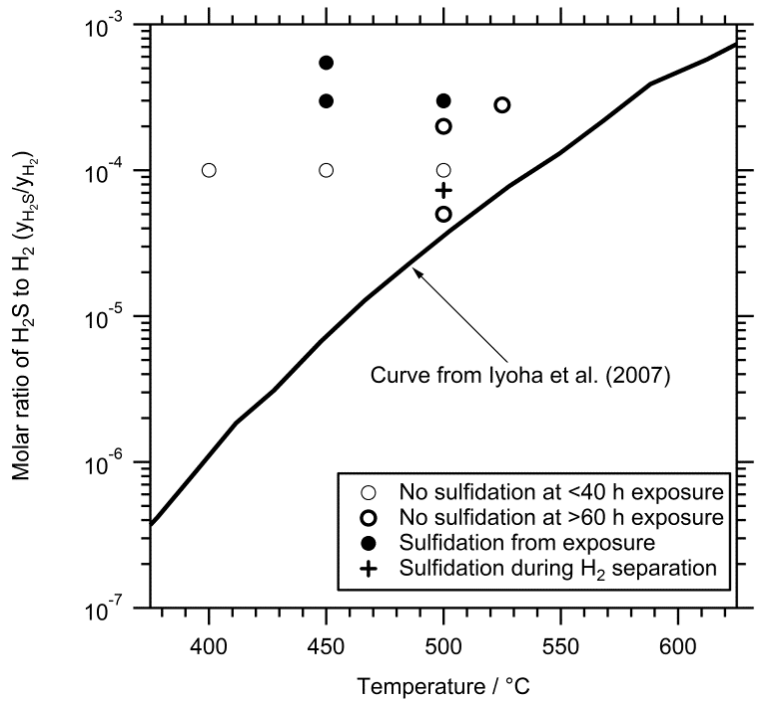

Figure 25: Iyoha et al. [15] thermodynamic equilibrium curve for $\mathrm{Pd}_{4} \mathrm{~S}$ formation and subscale test conditions and results. 
DE-FE0004967

United Technologies Research Center

Table 5: Conditions and results of sulfur exposure coupon testing.

\begin{tabular}{|c|c|c|c|c|c|c|}
\hline $\begin{array}{c}\text { Coupon } \\
\text { Identification }\end{array}$ & $\begin{array}{c}\text { Temperature / } \\
{ }^{\circ} \mathrm{C}\end{array}$ & $\begin{array}{c}\mathrm{H}_{2} \mathrm{~S} \text { conc. } / \\
\text { ppmv }\end{array}$ & $\mathrm{yH}_{2} \mathrm{~S} / \mathrm{yH}_{2}$ & $\begin{array}{c}\mathrm{CO}_{2}, \mathrm{H}_{2} \mathrm{O} \\
\text { in gas } \\
(\mathrm{Y} / \mathrm{N})\end{array}$ & Exposure Time / h & $\begin{array}{c}\text { Sulfur } \\
\text { Detected }(\mathrm{Y} / \mathrm{N})\end{array}$ \\
\hline $3-6 / 4.6$ & 400 & 104 & $1 \times 10^{-4}$ & $\mathrm{~N}-\mathrm{N}$ & 10.5 & $\mathrm{~N}$ \\
\hline $3-1 / 4-1$ & 450 & 104 & $1 \times 10^{-4}$ & $\mathrm{~N}-\mathrm{N}$ & 9 & $\mathrm{~N}$ \\
\hline $3-3 / 4-3$ & 450 & 104 & $1 \times 10^{-4}$ & $\mathrm{~N}-\mathrm{N}$ & 16 & $\mathrm{~N}$ \\
\hline $3-2 / 4-2$ & 450 & 104 & $1 \times 10^{-4}$ & $\mathrm{~N}-\mathrm{N}$ & 25 & $\mathrm{~N}$ \\
\hline $3-46 / 4-46$ & 450 & 163 & $3 \times 10^{-4}$ & $Y-Y$ & 12 & Y, surface only \\
\hline $3-42 / 4-42$ & 450 & 163 & $3 \times 10^{-4}$ & $Y-Y$ & 16 & $\mathrm{Y}$ \\
\hline $3-45 / 4-45$ & 450 & 163 & $3 \times 10^{-4}$ & $Y-Y$ & 31 & $\mathrm{Y}$ \\
\hline $3-43 / 4-43$ & 450 & 163 & $3 \times 10^{-4}$ & $Y-Y$ & 35 & $\mathrm{Y}$ \\
\hline $3-44 / 4-44$ & 450 & 163 & $3 \times 10^{-4}$ & $Y-Y$ & 47 & $\mathrm{Y}$ \\
\hline $3-121 / 4-121$ & 450 & 150 & $3 \times 10^{-4}$ & $\mathrm{~N}-\mathrm{Y}$ & 40 & $\mathrm{Y}$ \\
\hline $3-55 / 4-55$ & 450 & 270 & $5.5 \times 10^{-4}$ & $Y-Y$ & 12 & $\mathrm{Y}$ \\
\hline $3-51 / 4-51$ & 450 & 270 & $5.5 \times 10^{-4}$ & $Y-Y$ & 16 & $\mathrm{Y}$ \\
\hline $3-54 / 4-54$ & 450 & 270 & $5.5 \times 10^{-4}$ & $Y-Y$ & 24 & $\mathrm{Y}$ \\
\hline $3-52 / 4-52$ & 450 & 270 & $5.5 \times 10^{-4}$ & $Y-Y$ & 28 & $\mathrm{Y}$ \\
\hline $3-53 / 4-53$ & 450 & 270 & $5.5 \times 10^{-4}$ & $Y-Y$ & 40 & $\mathrm{Y}$ \\
\hline $3-81 / 4-81$ & 500 & 27 & $5.5 \times 10^{-5}$ & N-Y & 60 & $\mathrm{~N}$ \\
\hline $3-82 / 4-82$ & 500 & 27 & $5.5 \times 10^{-5}$ & $\mathrm{~N}-\mathrm{Y}$ & 120 & $\mathrm{~N}$ \\
\hline $3-83 / 4-83$ & 500 & 27 & $5.5 \times 10^{-5}$ & N-Y & 180 & $\mathrm{~N}$ \\
\hline $4-71 / 4-75$ & 500 & 385 & $2 \times 10^{-4}$ & N-Y & 47 & $\mathrm{~N}$ \\
\hline $4-72 / 4-73 / 4-74$ & 500 & 385 & $2 \times 10^{-4}$ & N-Y & 94 & $\mathrm{~N}$ \\
\hline $\begin{array}{l}3-91 / 3-92 / 3-93 \\
4-91 / 4-92 / 4-93\end{array}$ & 500 & 50 & $1 \times 10^{-4}$ & $\mathrm{~N}-\mathrm{Y}$ & 60 & $\mathrm{~N}$ \\
\hline $3-41 / 4-41$ & 500 & 163 & $3 \times 10^{-4}$ & Y-Y & 4 & $\mathrm{~N}$ \\
\hline $3-31 / 4-31$ & 500 & 163 & $3 \times 10^{-4}$ & $Y-Y$ & 12 & $\mathrm{~N}$ \\
\hline $3-37 / 4-37$ & 500 & 163 & $3 \times 10^{-4}$ & Y-Y & 16 & $\mathrm{~N}$ \\
\hline $3-38 / 4-38$ & 500 & 163 & $3 \times 10^{-4}$ & Y-Y & 24 & $\mathrm{Y}$ \\
\hline $3-39 / 4-39$ & 500 & 163 & $3 \times 10^{-4}$ & Y-Y & 28 & $\mathrm{Y}$ \\
\hline $3-85 / 4-85$ & 500 & 150 & $3 \times 10^{-4}$ & $\mathrm{~N}-\mathrm{Y}$ & 28 & Slight \\
\hline $3-112 / 4-112$ & 500 & 150 & $3 \times 10^{-4}$ & Y-Y & 28 & $\mathrm{Y}$ \\
\hline $3-101 / 4-101$ & 525 & 150 & $3 \times 10^{-4}$ & $\mathrm{~N}-\mathrm{Y}$ & 60 & $\mathrm{~N}$ \\
\hline $3-102 / 4-102$ & 525 & 150 & $3 \times 10^{-4}$ & $\mathrm{~N}-\mathrm{Y}$ & 120 & Defect? \\
\hline $\begin{array}{l}3-103 / 4-103 \\
/ 3-104 / 4-104\end{array}$ & 525 & 150 & $3 \times 10^{-4}$ & $\mathrm{~N}-\mathrm{Y}$ & 240 & $\mathrm{~N}$ \\
\hline
\end{tabular}

After exposure, the coupons were weighted and compared to their pre-exposure weight. The coupons were then mounted and inspected using a microscope at $1000 \times$ magnification. Some of the coupons were also evaluated using TEM. No $\mathrm{Pd}_{4} \mathrm{~S}$ was optically detected within the exposure time at the conditions tested. To more accurately mimic the actual separator operating conditions, a second set of experiments was performed including in the feed stream the full suite of gaseous compounds specified in the DOE test $2 \mathrm{a}$ (i.e., $\mathrm{H}_{2}, \mathrm{CO}, \mathrm{CO}_{2}$, and $\mathrm{H}_{2} \mathrm{O}$ ). The exposure times were also increased.

Table 5 gives a summary of the experimental conditions used for the various runs and shows whether sulfur was detected. The determination of the presence of sulfur was mostly made based on examination of digital microscopy images revealing the presence or absence of specific patterns known to be correlated with sulfur attack. In addition, a few samples were evaluated using TEM and EDS for different $\mathrm{yH}_{2} \mathrm{~S} / \mathrm{yH}_{2}$ ratios (coupons 4-31/4-39/4-41; 4-71/4-72; and 3$81 / 4-81 / 3-82 / 4-82)$. 
Figure 26 shows typical microscopy examples of instances of sulfur attack and no sulfur attack. For the majority of samples where sulfidation occurred, EDS confirmed that the "spot" patterns shown in Figure 26 contained sulfur. The sulfur to palladium atomic ratio was about 1:5 which is consistent with the formation of $\mathrm{Pd}_{4} \mathrm{~S}$. Coupon 3-102 that was run at $525^{\circ} \mathrm{C}$ and $\mathrm{yH}_{2} \mathrm{~S} / \mathrm{yH}_{2}=3 \times 10^{-4}$ for 120 hours presented a very different pattern of degradation since it exhibited a circle shaped pattern (see Figure 27). This pattern may have been due to the presence of a defect or to a rate difference between chemical reaction and diffusion at higher temperatures.

Figure 25 shows the test results for sulfur exposure compared to the thermodynamic equilibrium calculations from Iyoha [15]. Based on thermodynamics, operating below the Iyoha curve should not result in irreversible sulfur attack, whereas operating above curve should result in membrane failure. The data show that the $\mathrm{Pd}-\mathrm{Cu}$ membrane used in this project was more resistant to sulfur attack than predicted by thermodynamics. However, the testing was done under short exposure times relative to the desired operating lifetime of years. In addition, it is currently assumed that the sulfur diffuses through the $\mathrm{Pd}-\mathrm{Cu}$ matrix driven by a concentration gradient. However, the coupon testing was done under conditions where there was little or no concentration gradient across the membrane, which could affect sulfur diffusion rates through the bulk Pd-Cu matrix. Also plotted in Figure 25 is the maximum $\mathrm{yH}_{2} \mathrm{~S}_{\mathrm{yH}} \mathrm{H}_{2}$ ratio of $72.9 \times 10^{-6}$, where separator 5313 was shown to be attacked by sulfur. This value is still above the thermodynamic conditions, but below the conditions where coupons exposed without $\mathrm{H}_{2}$ transport and concentration gradients occur. Further investigation and characterization of membrane sulfidation was not possible before the end of this project.
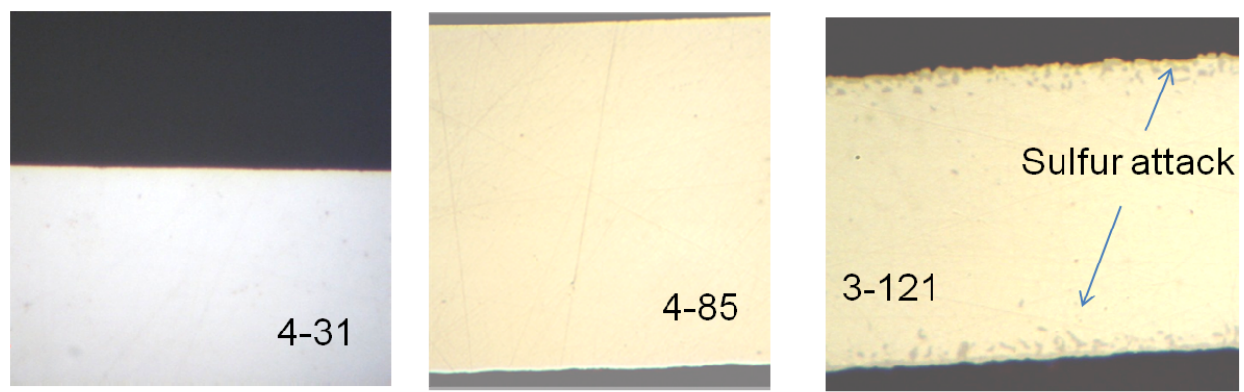

Figure 26: Digital photographs showing the specific pattern related to sulfur attack. Coupons 4-31 and 4-85 were not subject to sulfur attack whereas 3-121 shows indications of sulfidation.

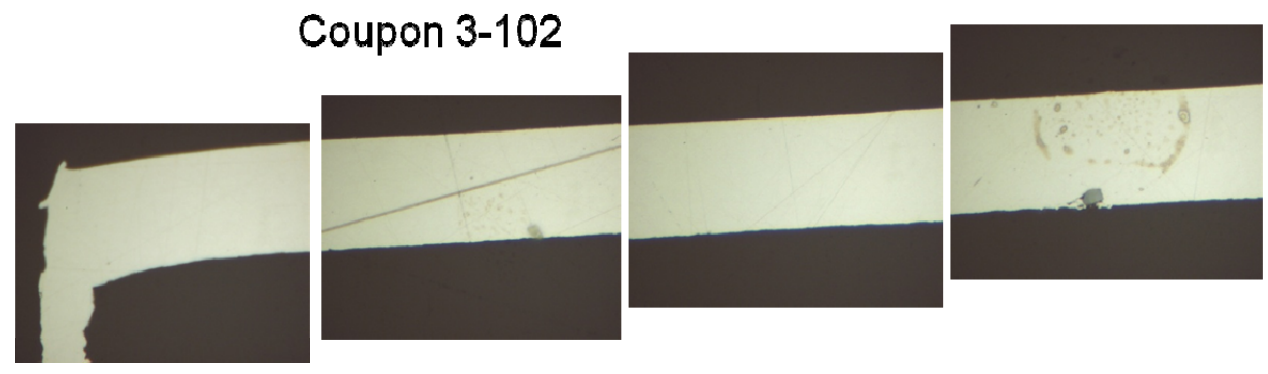

Figure 27: Digital microscope images of coupon 3-102, evaluated at $525^{\circ} \mathrm{C}$ and $\mathrm{yH}_{2} \mathrm{~S} / \mathrm{yH}_{2}=3 \times 10^{-4}$ for 120 hours, exhibiting an atypical ring circle pattern of sulfidation. 


\subsubsection{Separator 5312 Durability Study to Validate Model and DOE Targets}

To fully demonstrate the separation of $2 \mathrm{lb} \mathrm{day}^{-1} \mathrm{H}_{2}$ with a recovery of $95 \%$ without failure, a long-term durability test was initiated. Figure 28 shows the $\mathrm{H}_{2}$ permeation rate and operating conditions versus time for separator 5312, including the additional durability test. Separator 5312 was one of three separators evaluated downstream of coal gasifiers, all of which successfully demonstrated and exceeded the DOE targeted separation rate of $2 \mathrm{lb}$ day $^{-1} \mathrm{H}_{2}$ (see Section 3.4). The separator design proved to be leak tight and durable in the presence of gasifier exhaust contaminants at temperatures and pressures up to $500{ }^{\circ} \mathrm{C}$ and 500 psia.

Starting at point $\mathrm{C}$ in the Figure, the DOE testing protocol conditions were adjusted to increase the $\mathrm{H}_{2}$ to $75 \%$ and reduce the $\mathrm{H}_{2} \mathrm{~S}$ to $1.65 \mathrm{ppmv}$ from $20 \mathrm{ppmv}$. The gas volumetric composition was set at $75 \% \mathrm{H}_{2} / 1 \% \mathrm{CO} / 5 \% \mathrm{CO}_{2} / 19 \% \mathrm{H}_{2} \mathrm{O} / 1.65 \mathrm{ppmv}_{2} \mathrm{~S}$ to provide enough $\mathrm{H}_{2}$ to meet the recovery target and to ensure that, at very high $\mathrm{H}_{2}$ recoveries, the $\mathrm{H}_{2} \mathrm{~S}$ was not in a high enough concentration to cause irreversible sulfidation of the membrane tubes. A key scientific finding of this project was the determination that, when the $\mathrm{H}_{2} \mathrm{~S}$ to $\mathrm{H}_{2}$ molar ratio within a separator tube exceeds $72.9 \times 10^{-6}$ at $500^{\circ} \mathrm{C}$, irreversible sulfur attack and membrane failure can occur.

During sulfur exposure at a mean temperature of $(500.8 \pm 10.6){ }^{\circ} \mathrm{C}$ and pressure of $(184.7 \pm 7.8) \mathrm{psig}$, the membrane separated $\mathrm{H}_{2}$ at a rate of $(2.36 \pm 0.20) \mathrm{lb}_{\mathrm{bay}}{ }^{-1} \mathrm{H}_{2}$ with a recovery of $(93.4 \pm 8.0) \%$, meeting the DOE project targets for $\approx 1300$ hours. The experience during this project was that for any test where the critical ratio was exceeded, membrane failure occurred in less than 400 hours, and thus this durability test validates the work on the $\mathrm{H}_{2} \mathrm{~S}$ to $\mathrm{H}_{2}$ molar ratio.

Starting at point D (2624 hours) in Figure 28, a small leak developed during the durability test which affected the ability of the separator to hold high pressures. As a result, $\mathrm{N}_{2}$ permeation measurements were periodically taken during the experiment to calculate the ideal $\mathrm{H}_{2} / \mathrm{N}_{2}$ separation factor at $500{ }^{\circ} \mathrm{C}$ and $52.65 \mathrm{psig}$. The $\mathrm{N}_{2}$ flow rate and calculated separation factor versus time are given in Figure 29. Based on the ideal separation factor, the small leak caused a small reduction in $\mathrm{H}_{2}$ purity from $99.9999 \%$ to approximately $99.98 \%$, but allowed operation to continue, unlike typical burst failures due to mechanical stresses or irreversible $\mathrm{H}_{2} \mathrm{~S}$ attack. A loess analysis $[32,33]$ of the leak data was performed which indicated that the $\mathrm{N}_{2}$ leak had stabilized around 3800 hours time on stream, as shown in Figure 29. No characterization or separator teardown was performed to determine the root cause of the leak before the project period of performance came to an end. 


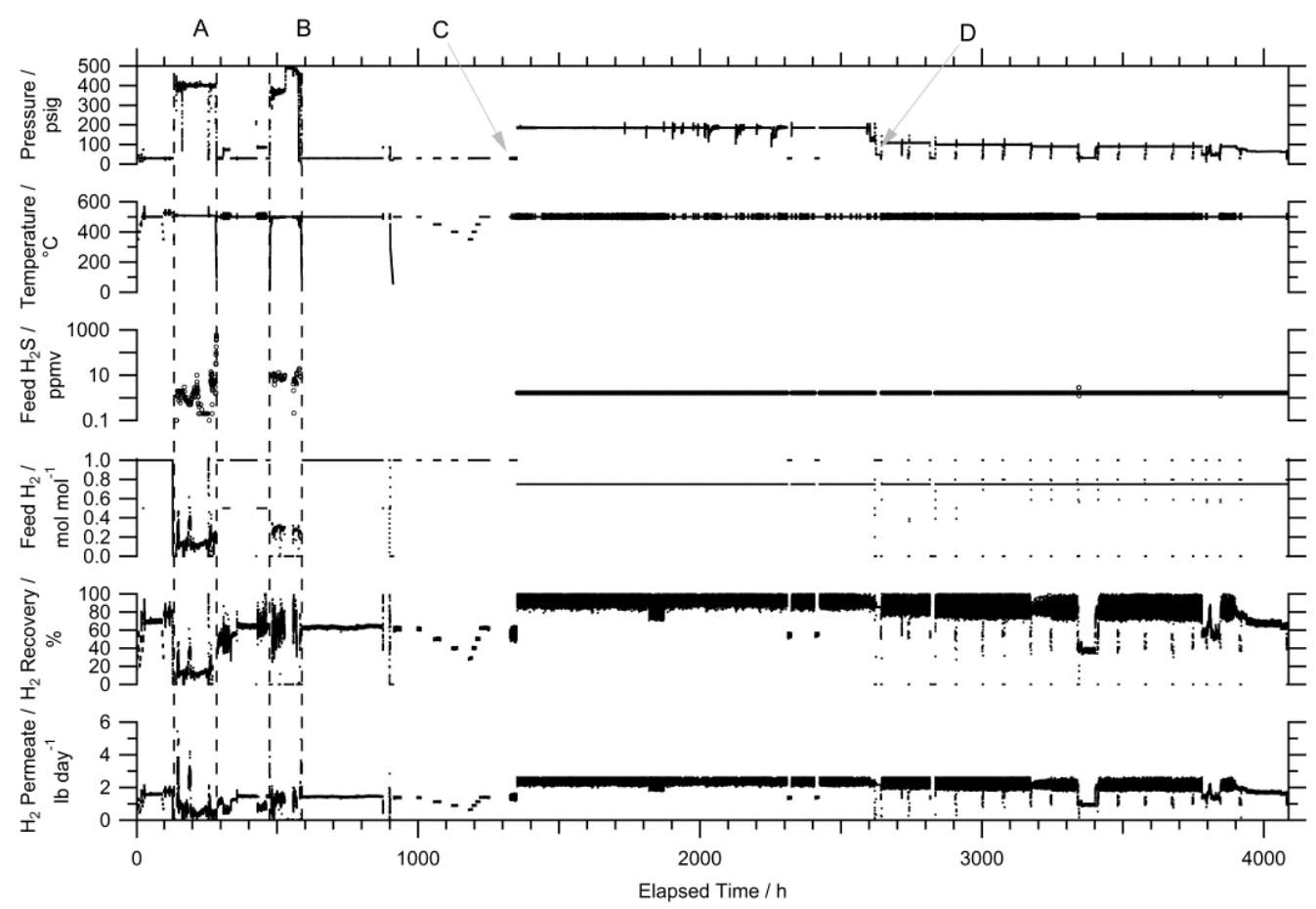

Figure 28: $\mathrm{H}_{2}$ permeate flow and operating conditions versus time for separator 5312 tested for 4087 hours (0.47 years). The regions labeled $A$ and $B$ were gasifier tests conducted at EERC in January and February 2012 for a combined coal syngas exposure time of 189 hours. Point $\mathrm{C}$ at 1326 hours marks the beginning of a durability test demonstrating $>2 \mathrm{lb} \mathrm{day}^{-1} \mathrm{H}_{2}$ at $95 \%$ recovery in the presence of $1.7 \mathrm{ppmv} \mathrm{H}_{2} \mathrm{~S}$. Point $\mathrm{D}$ at 2624 hours marks the beginning of a small leak in the separator, reducing the $\mathrm{H}_{2}$ purity below 99.9999\%.

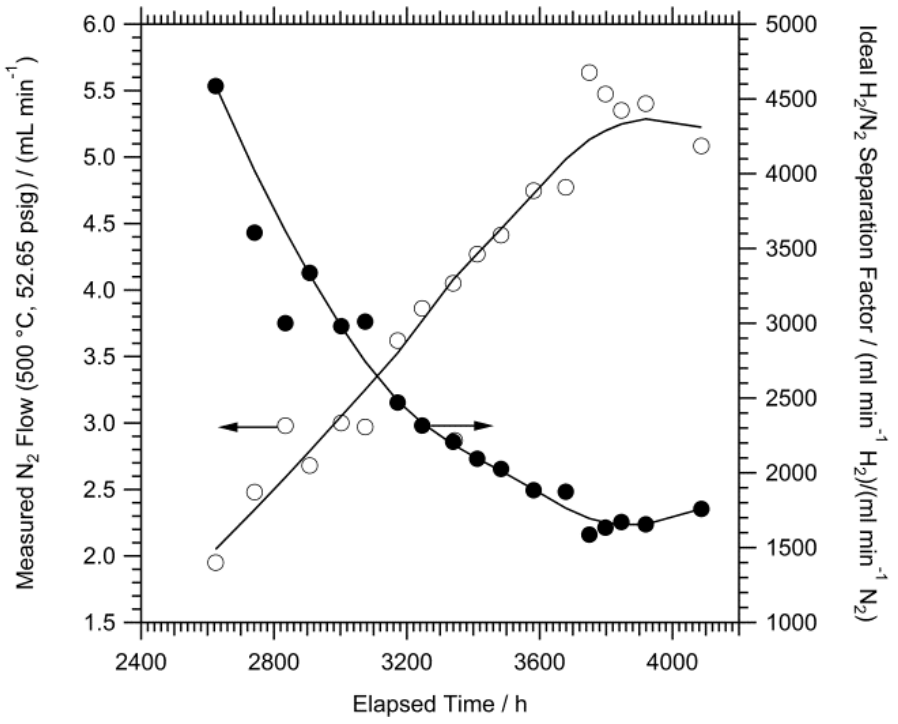

Figure 29: Measured $\mathrm{N}_{2}$ flow rate and calculated ideal $\mathrm{H}_{2} / \mathrm{N}_{2}$ separation factor as a function of time for separator 5312 starting at time 2624 hours. 


\subsection{Pilot Scale (2 lb/day $\mathrm{H}_{2}$ ) Gasifier Testing}

Three different pilot-scale $\left(\approx 1.5 \mathrm{ft}^{2}\right)$ separators were evaluated downstream of coal gasifiers during four different tests. During three of those tests, all of the separators demonstrated or exceeded the targeted separation rate of $2 \mathrm{lb} d a y^{-1} \mathrm{H}_{2}$. The separator design was proved to be leak tight and durable in the presence of gasifier exhaust contaminants at temperatures and pressures up to $500{ }^{\circ} \mathrm{C}$ and 500 psia.

The contaminants in the coal gasifier syngas for the most part had negligible impact on separator performance, with $\mathrm{H}_{2}$ partial pressure being the greatest determinant of membrane performance. Carbon monoxide and low levels of $\mathrm{H}_{2} \mathrm{~S}(<39 \mathrm{ppmv})$ had no effect on $\mathrm{H}_{2}$ permeability, in agreement with laboratory experiments. However, higher levels of $\mathrm{H}_{2} \mathrm{~S}$ $(>100 \mathrm{ppmv})$ were shown to significantly reduce $\mathrm{H}_{2}$ separation performance. The presence of trace metals, including mercury and arsenic, appeared to have no effect based on the experimental data.

Conditions that have a thermodynamic driving force to form coke were found to reduce the performance of the separators, presumably by blockage of effective separation area with carbon deposits. However, it was demonstrated that both in situ and ex situ (laboratory) air regeneration at $450{ }^{\circ} \mathrm{C}$ could restore separator performance by burning out such deposits.

Gasifier testing revealed that high molecular weight hydrocarbons have the potential to retard $\mathrm{H}_{2}$ separation. Unconverted coal tars with carbon numbers greater than 14 have a boiling point such that they can act as a reversible poison to the $\mathrm{Pd}-\mathrm{Cu}$ membranes even at temperatures above $500{ }^{\circ} \mathrm{C}$. The use of real-time, physics-based, performance models revealed the effect of these coal tars. It is believed that this project provided the first evidence for the impact of coal tars on $\mathrm{H}_{2}$ separator performance.

\subsubsection{Separator 5298 Gasifier Test}

In July 2011 , two pilot-scale $\left(\approx 1.5 \mathrm{ft}^{2}\right)$ separators were shipped to EERC as test articles. Prior to shipment, they were leak tested at UTRC and their hydrogen separation performance was verified to provide a baseline for the gasifier test. One of the separators was installed in EERC's gasifier test rig and the baseline test was repeated, including leak checks and a hydrogen separation performance test.

Prior to testing, a detailed test plan was developed in coordination with EERC to ensure that the operating conditions of the gasifier and the separator would achieve the hydrogen flux and recovery targets. The separator performance under gasifier conditions was predicted using a UTRC-developed, physics-based mathematical model. The model was validated during the course of the project through the simulation of the performance of several laboratory-scale $\left(\approx 0.1 \mathrm{ft}^{2}\right)$ separators that were tested with different gas compositions, including the DOE test 1 and 2 protocol conditions.

Based on modeling results for a $40 \%$ to $45 \%$ hydrogen feed gas, the separator testing conditions for the EERC gasifier run were broken into three modes. The goal of the first mode of operation was to maximize hydrogen recovery by keeping the separator at $500{ }^{\circ} \mathrm{C}$ and $400 \mathrm{psia}$ with a feed flow rate of $16 \pm 0.8 \mathrm{~L} \mathrm{~min}^{-1}$, resulting in a predicted separation of $2 \mathrm{lb} \mathrm{day}^{-1}$ hydrogen. The goal of the second mode of operation was to maximize hydrogen flux $\left(\geq 20 \mathrm{ft}^{3} \mathrm{ft}^{-2} \mathrm{~h}^{-1}\right.$ ) by increasing the flow rate to at least $90 \pm 4.5 \mathrm{~L} \mathrm{~min}^{-1}$, resulting in a predicted separation of at least $4 \mathrm{lb}$ day $^{-1}$ hydrogen, but at a lower hydrogen recovery $(\approx 40 \%)$. In the first two modes of operation, the feed flow was to be directed through EERC's desulfurization system, thereby producing a low sulfur feed stream. The goal of the third mode of operation was 
to increase the sulfur concentration of the feed flow $\left(\geq 90 \mathrm{~L} \mathrm{~min}^{-1}\right)$ to approximately $100 \mathrm{ppmv}$ sulfur (at 400 psia) by partially bypassing EERC's desulfurization system. Based on testing done at UTRC, this partial pressure of sulfur $(0.04$ psia $S)$ was expected to reduce the hydrogen flux by half, allowing the separator to achieve the DOE target of $2 \mathrm{lb}_{\text {day }}{ }^{-1} \mathrm{H}_{2}$.

The one week gasifier test began the evening of 31 July 2011 with the startup of EERC's fluid bed gasifier and ended on 5 August 2011. The gasifier was operated as close as possible to pure oxygen-blown conditions. Due to hot spots and accumulation of unreacted solids under these conditions, the gasifier had difficulties operating continuously for long periods of time and ultimately, the separator was tested for a total of 64 hours downstream of the gasifier.

The data from the gasifier test are summarized in Figure 30. For the first 24 hours of the test, the separator was tested with bottled hydrogen and nitrogen to establish a baseline performance while the gasifier operation was stabilized. With approximately $6 \mathrm{~L} \mathrm{~min}^{-1}$ pure hydrogen from a cylinder, $1.47 \pm 0.10 \mathrm{lb} \mathrm{day}^{-1} \mathrm{H}_{2}$ was separated with a hydrogen recovery of $(79.7 \pm 3.6) \%$. The separator was then tested for approximately 12 hours during the first mode of operation to maximize recovery, achieving a hydrogen separation rate of $0.69 \pm 0.15 \mathrm{lb} \mathrm{day}^{-1}$ with a recovery of $(71.2 \pm 10.5) \%$. The majority of the remaining testing time was spent under the second mode of operation to maximize flux and achieve the target hydrogen separation rate. The operating conditions were adjusted several times during this period and the gasifier was shut down once, resulting in a 24 hour delay in the middle of the test. Once the gasifier was restarted at a different operating condition, the separator achieved a hydrogen separation rate of $2.06 \pm 0.16 \mathrm{lb} \mathrm{day}^{-1}$ with a recovery of $(17.2 \pm 1.2) \%$.

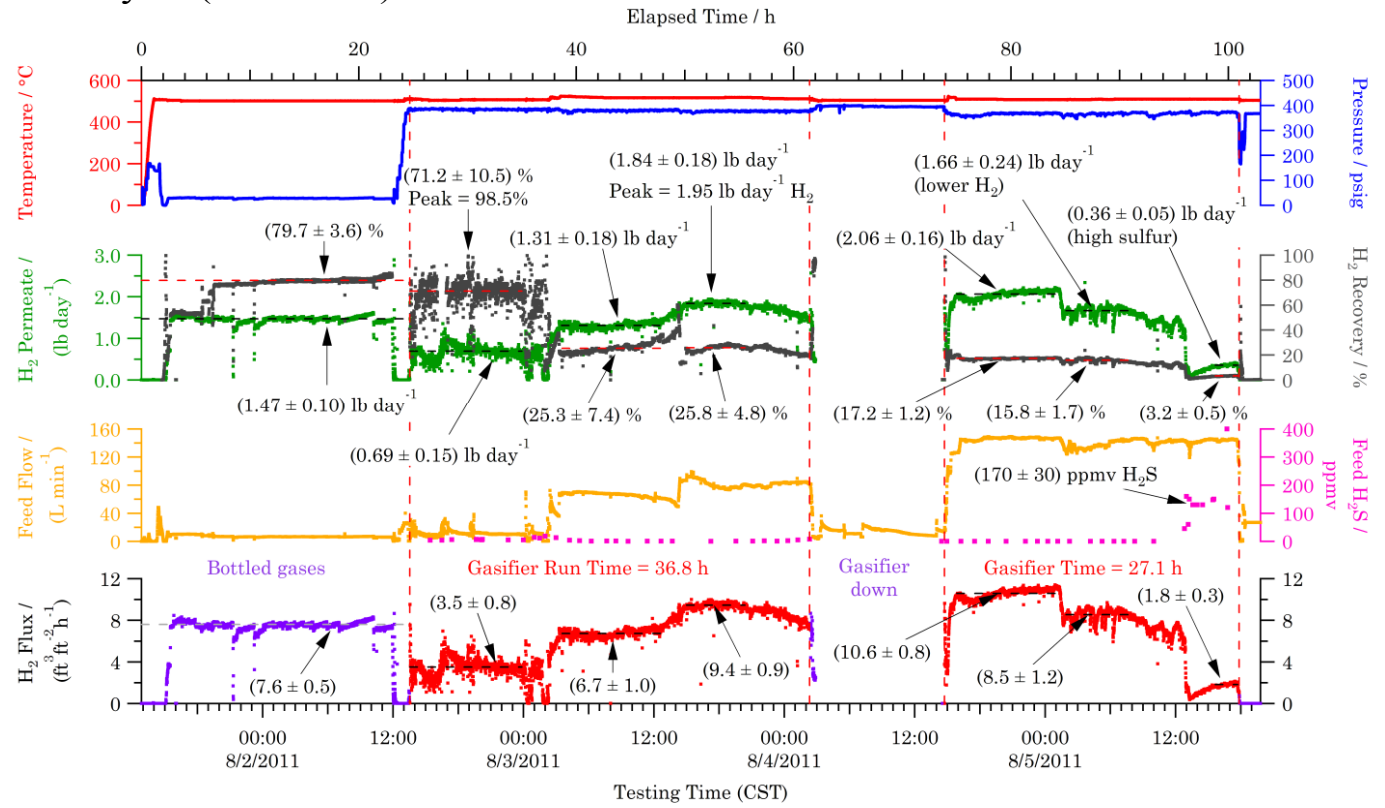

Figure 30: Data summary of coal gasifier test in August 2011 of pilot-scale separator 5298. The separator was tested with gasifier exhaust for a total of 64 hours. Under the best gasifier operating conditions, $2.06 \pm 0.16 \mathrm{lb} \mathrm{day}^{-1} \mathrm{H}_{2}$ was separated at an operating pressure of 400 psia.

In the last 10 hours of gasifier operation, the EERC desulfurizer was partially bypassed to test the separator under the third mode of operation in the test plan. As the bypass valve system was adjusted and the sulfur concentration increased, the hydrogen separation rate decreased. Eventually, the sulfur concentration, as measured by Dräger tubes, stabilized at 
$170 \pm 30 \mathrm{ppmv} \mathrm{H}_{2} \mathrm{~S}$. Prior to the increase in sulfur levels, the separator permeate flow rate was $1.66 \pm 0.24 \mathrm{lb} \mathrm{day}^{-1} \quad \mathrm{H}_{2}$ with a recovery of $(15.8 \pm 1.7) \%$. These values decreased by approximately a factor of five to $0.36 \pm 0.05 \mathrm{lb}$ day $^{-1} \mathrm{H}_{2}$ with a recovery of $(3.2 \pm 0.5) \%$ on exposure to the high sulfur concentrations. After approximately 6 hours at these high sulfur levels, the test ended when the gasifier shut down again due to the challenging operating conditions.

During the test, the total wet hydrogen concentration available from the gasifier varied between $15 \%$ and $20 \%$, less than half what was anticipated in the test plan, resulting in the lower hydrogen separation rates. Nevertheless, the separator demonstrated the separation of $2.06 \pm 0.16 \mathrm{lb} \mathrm{day}^{-1} \mathrm{H}_{2}$ at an operating pressure of $400 \mathrm{psia}$, achieving the overall project objective. In addition, the separator demonstrated a mean hydrogen separation of $0.36 \pm 0.05 \mathrm{lb} \mathrm{day}^{-1} \mathrm{H}_{2}$ in the presence of $170 \pm 30 \mathrm{ppmv}_{2} \mathrm{~S}$.

\subsubsection{Separator 5307 Gasifier Test}

In August 2011, a pilot-scale $\left(\approx 1.5 \mathrm{ft}^{2}\right)$ separator (5307) was shipped to EERC as a test article for a second gasifier test. Prior to shipment, the separator was leak tested at UTRC and its hydrogen separation performance was verified to provide a baseline for the gasifier test. The second test occurred during the last week of September 2011. The experiment consisted of placing a separator downstream of EERC's gasifier during a test for Great Point Energy at a higher pressure than the previous test on separator 5298.

The data from the gasifier test are summarized in Figure 31. The separator was tested for a total of 77 hours downstream of the gasifier. Particularly during the first half of the run, a significant build up of water was detected in the exhaust thermal oxidizer for the system which resulted in pressure fluctuations and subsequent noise in the pressure and flow rate measurements. In addition, there was a higher uncertainty in the feed hydrogen measurement which impacted the ability to accurately calculate the overall hydrogen recovery. The noise was significantly reduced during the last 35 hours of data collection, enabling a more accurate estimation of separator performance. Separator 5307, in contrast to separator 5298, contained enhanced $\mathrm{Pd}-\mathrm{Cu}$ membranes and demonstrated the separation of $2.43 \pm 0.1 \mathrm{lb} \mathrm{day}^{-1} \mathrm{H}_{2}$ $\left(12.5 \pm 0.1 \mathrm{ft}^{3} \mathrm{ft}^{-2} \mathrm{~h}^{-1} \mathrm{H}_{2}\right)$ at an operating pressure of 498 psia with a $\mathrm{H}_{2}$ recovery of $(74.3 \pm 0.3) \%$. This was in close agreement with the UTRC model projection of $2.32 \mathrm{lb} \mathrm{day}^{-1} \mathrm{H}_{2}$ $\left(11.9 \mathrm{ft}^{3} \mathrm{ft}^{-2} \mathrm{~h}^{-1} \mathrm{H}_{2}\right)$ with a $\mathrm{H}_{2}$ recovery of $70.1 \%$.

\subsubsection{Separator 5307 Post-Gasifier Laboratory Testing}

Figure 32 shows the summary data versus time for the post-gasifier testing of separator 5307 in the laboratory. After the September 2011 test, separator 5307 showed slightly less than full performance in laboratory testing, with the $\mathrm{H}_{2}$ flux between $89.5 \%$ and $91.1 \%$ of the original laboratory testing. Experiments at UTRC have repeatedly shown that the initial, clean, $\mathrm{H}_{2}$ separation performance reduces slightly over time by up to approximately $10 \%$. As a result, full $\mathrm{H}_{2}$ separation performance is defined as $\geq 90 \%$ of the initial laboratory pure $\mathrm{H}_{2}$ measurements after original receipt at UTRC. For the data shown in Figure 34, the testing data after the September 2011 gasifier run were within that range, suggesting that separator 5307 had not been impacted by the gasifier exhaust. 
DE-FE0004967

United Technologies Research Center

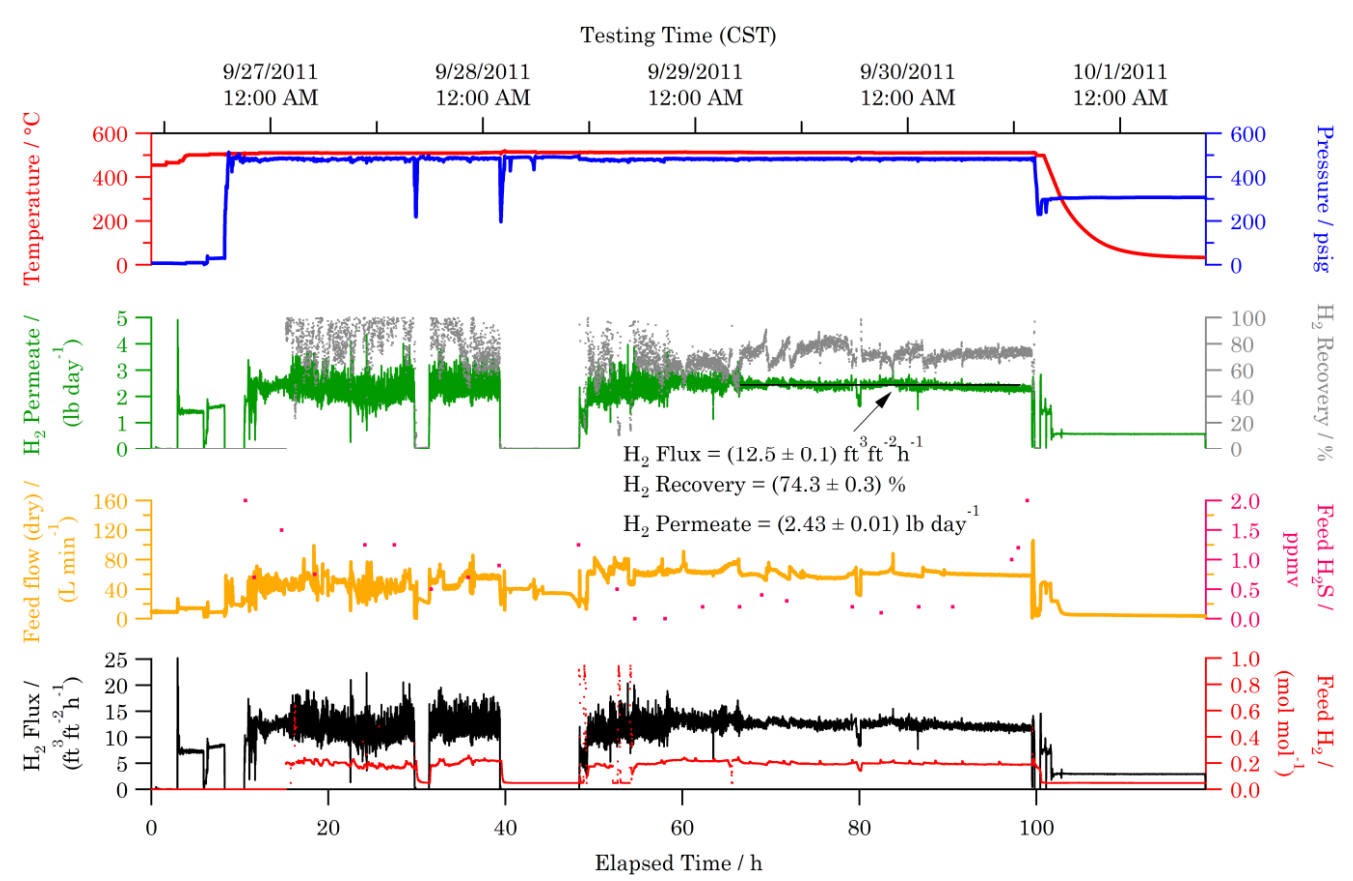

Figure 31: Data summary of coal gasifier test in September 2011 of pilot-scale separator 5307. The separator was tested with gasifier exhaust for a total of 77 hours and separated $2.43 \pm 0.01 \mathrm{lb} \mathrm{day}^{-1} \mathrm{H}_{2}$ at a mean operating pressure and temperature of 498 psia and $511^{\circ} \mathrm{C}$.

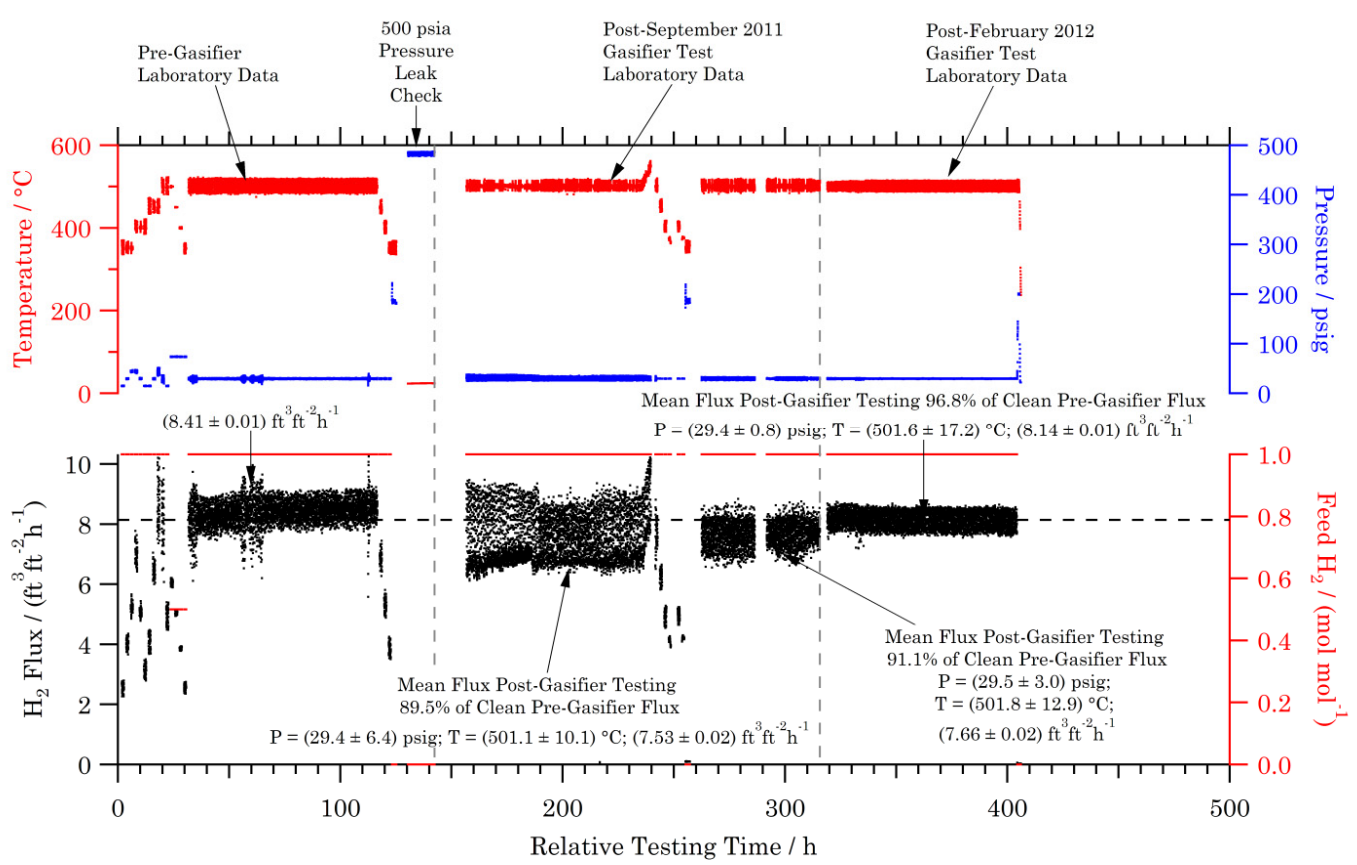

Figure 32: Laboratory testing data for separator 5307 before and after September 2011 and February 2012 gasifier test runs at EERC. 


\subsubsection{Separator 5312 Gasifier Test}

In January 2012 , another pilot-scale $\left(\approx 1.5 \mathrm{ft}^{2}\right)$ separator $(5312)$ was tested at EERC for a third gasifier test. Prior to shipment, the separator was leak tested at UTRC and its hydrogen separation performance was verified to provide a baseline for the gasifier test. The experiment consisted of placing two separators, in parallel, downstream of EERC's transport reactor development unit (TRDU). Separator 5312 was one of the two separators evaluated during the test. The other separator was from another DOE contract under the same NETL program office. The objective of the UTRC membrane test was to gain additional operating time downstream of a gasifier at 400 psia and $500{ }^{\circ} \mathrm{C}$.

The TRDU is a pilot-scale gasification unit capable of producing up to $400 \mathrm{lb} \mathrm{day}^{-1} \mathrm{H}_{2}$. The TRDU at EERC has an operating temperature of up to $1040{ }^{\circ} \mathrm{C}$ and an operating pressure of approximately $120 \mathrm{psig}$. EERC's membrane test system, which was used for previous UTRC gasifier tests, was relocated to the TRDU gasification tower. A slipstream of syngas from the TRDU was taken after hot gas filtration and pulled through heat traced lines at $289^{\circ} \mathrm{C}$. Steam was mixed with the syngas and the gas mixture was fed through two beds of KATALCOJM ${ }^{\mathrm{TM}}$ K8-11 sour-shift catalyst. After the shift beds, the converted syngas was passed over a bed of RVS-1 regenerable sorbent to remove sulfur and other trace contaminants. The exhaust gas from the sorbent bed was then cooled in a series of quench pots to remove moisture prior to compression in a gas booster system. The higher pressure gas was then fed to the EERC membrane test skid.

The TRDU operation was conducted for the Western Research Institute (WRI) as part of a project with the State of Wyoming's Clean Coal Technologies Research Program and the North Dakota Industrial Commission. The TRDU testing consisted of evaluating different treatment methods with different coal feed sources. For the purposes of the membrane separator test, the different feed sources were simply identified as raw, dried, or treated coal. The coal sources were either Powder River Basin (PRB) or Lignite. Thus, the feed source during the gasifier testing changed at least six times, in addition to any changes in gasifier operating conditions. Due to the combination of operating conditions and coal feed source, the hydrogen concentration in the gasifier syngas was expected to be lower than previous tests.

The data from the gasifier test on separator 5312 are summarized in Figure 33. The separator was tested for $130 \mathrm{~h}$ under different gasifier conditions involving two different types of coal with different coal pre-treatment steps. Throughout the run, there were periods (e.g., 32 to 36 hours and 132 to 136 hours) where the membrane feed was switched to house $\mathrm{N}_{2}$ and no flow rate was detected on the permeate side, indicating that the separator was leak tight at an average condition of $507^{\circ} \mathrm{C}$ and 401 psia. Due to the low concentration of $\mathrm{H}_{2}$ in the gasifier exhaust $(12 \% \pm 4 \%)$, the membrane separated an average of $0.48 \pm 0.28 \mathrm{lb} \mathrm{day}^{-1} \mathrm{H}_{2}$, although there were periods where greater than $3.02 \mathrm{lb}$ day $^{-1} \mathrm{H}_{2}$ was separated, particularly when bottled $\mathrm{H}_{2}$ was added to the separator feed gas. Because the $\mathrm{H}_{2}$ concentration was so low and the upper pressure limit of the other separator was approximately $200 \mathrm{psig}$, to increase its performance the other DOE contractor requested that bottled $\mathrm{H}_{2}$ be injected into the membrane feed system early in the run and later after approximately 50 hours.

Dräger tubes were used throughout this run, as in previous gasifier runs, to quantify the sulfur concentration in the feed to the separator from gas sample ports. In addition, Dräger tubes were used periodically to check other gas contaminants, such as $\mathrm{NH}_{3}, \mathrm{HCN}$, and $\mathrm{HCl}$. For most of the run, the concentrations of these species were zero, although there were some concentration spikes of $\mathrm{NH}_{3}$ up to $10 \mathrm{ppmv}$. Analysis of the feed gas for trace metals was performed at the 
beginning (from 12 hours to 28 hours) and middle (from 59 hours to 91 hours) of the run with the results shown in Table 6. More frequent sampling of mercury was also performed, with a maximum value of $1.51 \mu \mathrm{g} \mathrm{m}^{-3} \mathrm{Hg}$ detected between 37 hours and 51 hours during the run.

The sulfur concentration $\left(\mathrm{H}_{2} \mathrm{~S}\right)$ recorded during the run is plotted in Figure 33, which shows that for most of the test the concentration was below 2 ppmv. However, the concentration spiked at approximately 81 hours to 10 ppmv and at approximately 131 hours to $14 \mathrm{ppmv}$, both times corresponding to a breakthrough in the RVS-1 sorbent bed, requiring a switch to a new sorbent bed. Assuming that the membrane can tolerate an $\mathrm{H}_{2} \mathrm{~S}$ to $\mathrm{H}_{2}$ ratio of $7.29 \times 10^{-5}$, the acceptable $\mathrm{H}_{2} \mathrm{~S}$ feed concentrations at these two moments were 7 ppmv and 13 ppmv, respectively. Thus, separator 5312 was exposed to potential sulfidation conditions for approximately 30 minutes out of the total 130 hours of exposure to shifted gasifier exhaust. Experimental testing has shown that more than 300 hours of exposure at sulfiding conditions is required to fail one of the UTRC separators and therefore that these brief exposures were considered tolerable.

It was revealed through real-time modeling during the gasifier test that separator 5312 had been partially deactivated during the run, most likely from coke formation inside the separator due to an upset in gas composition. Approximately 19 hours after the start of the experiment shown in Figure 33, steam addition was lost to the sour-shift bed system for an hour, resulting in a low $\mathrm{O} / \mathrm{C}$ mixture with high concentrations of carbon monoxide that had a thermodynamic potential to form carbon at $500{ }^{\circ} \mathrm{C}$. Verification of the deactivation was further confirmed at approximately 124 hours into the run, where both separators were operated on pure $\mathrm{H}_{2}$. Under pure $\mathrm{H}_{2}$, the membrane separated $\mathrm{H}_{2}$ at $2.07 \pm 0.04 \mathrm{lb}$ day $^{-1}$ with a $\mathrm{H}_{2}$ recovery of $(58.4 \pm 1.7) \%$. However, the pure $\mathrm{H}_{2}$ performance at $504{ }^{\circ} \mathrm{C}$ and $(73.2 \pm 0.5)$ psig should have been $3.24 \mathrm{lb}$ day $^{-}$ ${ }^{1}$ with a $\mathrm{H}_{2}$ recovery of $92.7 \%$.

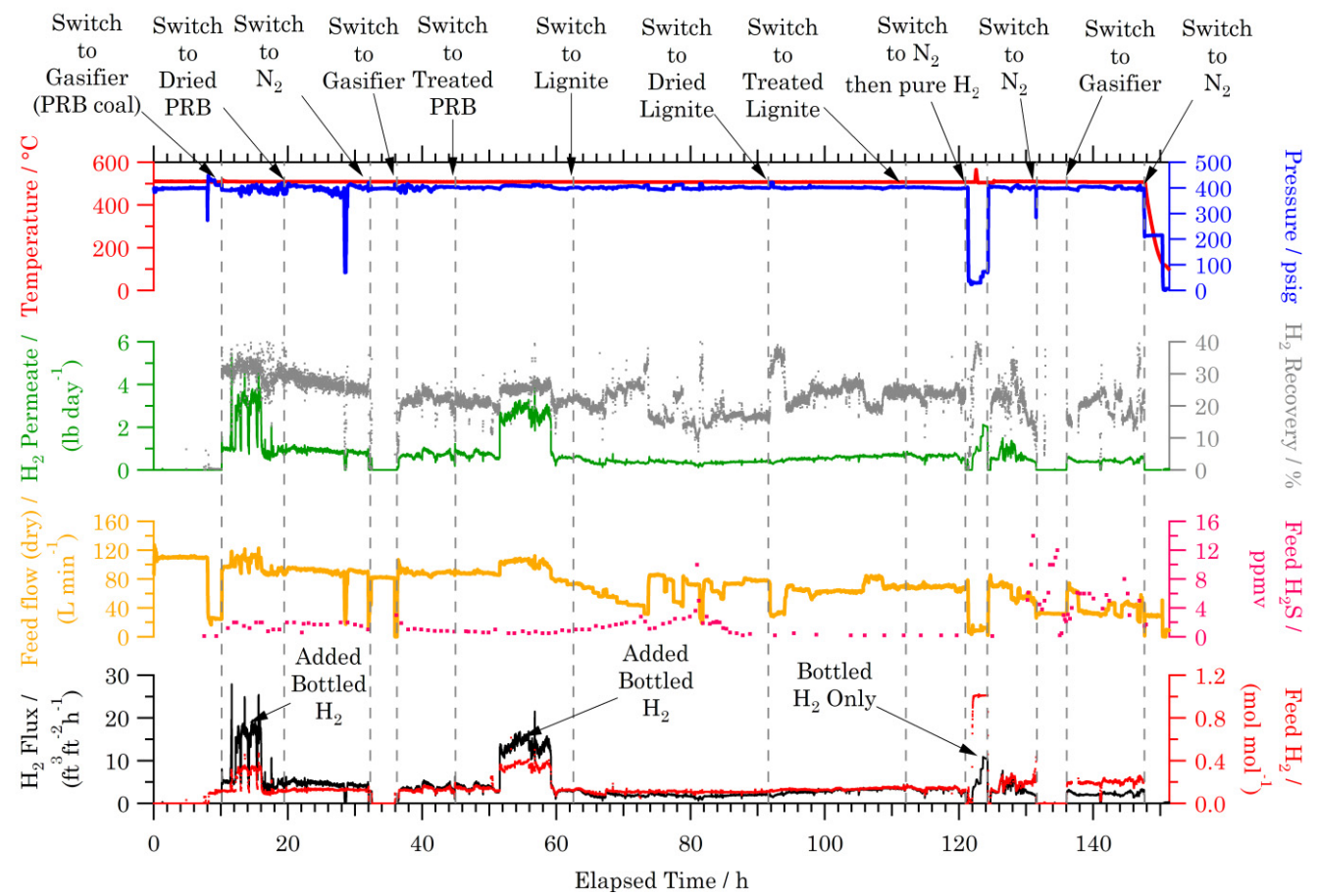

Figure 33: Data summary of coal gasifier test in January 2012 of pilot-scale separator 5312. The separator was tested with gasifier exhaust for a total of 130 hours and separated an average of $0.48 \pm 0.28 \mathrm{lb} \mathrm{day}^{-1} \mathrm{H}_{2}$ at a mean operating pressure and temperature of 401 psia and $507^{\circ} \mathrm{C}$. During the first bottled $\mathrm{H}_{2}$ addition, $>3.02 \mathrm{lb} \mathrm{day}^{-1} \mathrm{H}_{2}$ was separated. 
Table 6: Trace metal concentrations in separator 5312 feed gas during the January 2012 TRDU gasifier run at EERC.

\begin{tabular}{lcc}
\hline Trace element & Concentration $(12-28 \mathrm{~h}) / \mu \mathrm{g} \mathrm{m}^{-3}$ & Concentration $(59-91 \mathrm{~h}) / \mu \mathrm{g} \mathrm{m}^{-3}$ \\
\hline Antimony & $<0.9$ & $<0.9$ \\
Arsenic & $<3.1$ & $<2.9$ \\
Beryllium & $<0.2$ & $<0.2$ \\
Cadmium & $<1.0$ & $<1.0$ \\
Chromium & 28.5 & 45.7 \\
Cobalt & $<1.0$ & 1.3 \\
Lead & $<1.3$ & 1.5 \\
Manganese & 33.7 & $<61.5$ \\
Mercury & $<0.01$ & $<0.09$ \\
Nickel & 5.4 & 6.5 \\
Selenium & $<0.2$ & $<0.2$ \\
\hline
\end{tabular}

\subsubsection{Separator 5312 Post-Gasifier Laboratory Testing (Air Regeneration)}

Figure 34 shows the summary data versus time for the post-gasifier testing of separator 5312 in the laboratory. After the January 2012 test, separator 5312 showed less than full performance in laboratory testing, with the $\mathrm{H}_{2}$ permeate flow rate on pure $\mathrm{H}_{2}$ less than $1 \mathrm{~L} \mathrm{~min}^{-1}$ below normal. Testing with a $50 \% \mathrm{H}_{2} / 50 \% \mathrm{H}_{2} \mathrm{O}$ feed mixture at $500{ }^{\circ} \mathrm{C}$ and then $550{ }^{\circ} \mathrm{C}$ brought back some additional permeate flow, but the separator was still underperforming. However, after a 2-hour exposure to flowing air at $450^{\circ} \mathrm{C}$, the separator regained its full $\mathrm{H}_{2}$ separation performance and was shown to be still leak tight.

Experiments at UTRC have shown that many times the initial, clean, $\mathrm{H}_{2}$ separation performance reduces slightly over time by up to approximately $10 \%$. As a result, full $\mathrm{H}_{2}$ separation performance is defined as $\geq 90 \%$ of the initial laboratory pure $\mathrm{H}_{2}$ measurements after original receipt at UTRC. For the data shown in Figure 34, all post-gasifier testing after the air regeneration were $90.7 \%$ of the initial $\mathrm{H}_{2}$ flux measured in the laboratory. Thus, any contaminants, such as coke, that were within the separator from the gasifier run were removed by burning them out.

Once separator 5312's performance was restored by air regeneration, a series of tests were performed at $100 \mathrm{psia}$ and $500{ }^{\circ} \mathrm{C}$ to examine the impact of $\mathrm{CO}$ on performance. The separator was exposed to a $50 \% \mathrm{H}_{2} / 50 \% \mathrm{H}_{2} \mathrm{O}$ feed mixture, followed by a $50 \% \mathrm{H}_{2} / 2 \% \mathrm{CO} / 48 \% \mathrm{H}_{2} \mathrm{O}$ mixture, and finally a $50 \% \mathrm{H}_{2} / 16 \% \mathrm{CO} / 34 \% \mathrm{H}_{2} \mathrm{O}$ feed. The performance with and without $\mathrm{CO}$ addition was identical. A $50 \% \mathrm{H}_{2} / 50 \% \mathrm{~N}_{2}$ feed mixture was also used for testing with the same results. Pure $\mathrm{H}_{2}$ tests before and after exposure to the gas mixtures showed no change in separator permeability and checks were performed to show that the separator was leak tight. Thus, it appeared that $\mathrm{CO}, \mathrm{N}_{2}$, and $\mathrm{H}_{2} \mathrm{O}$ did not affect separator permeability at $500{ }^{\circ} \mathrm{C}$. 


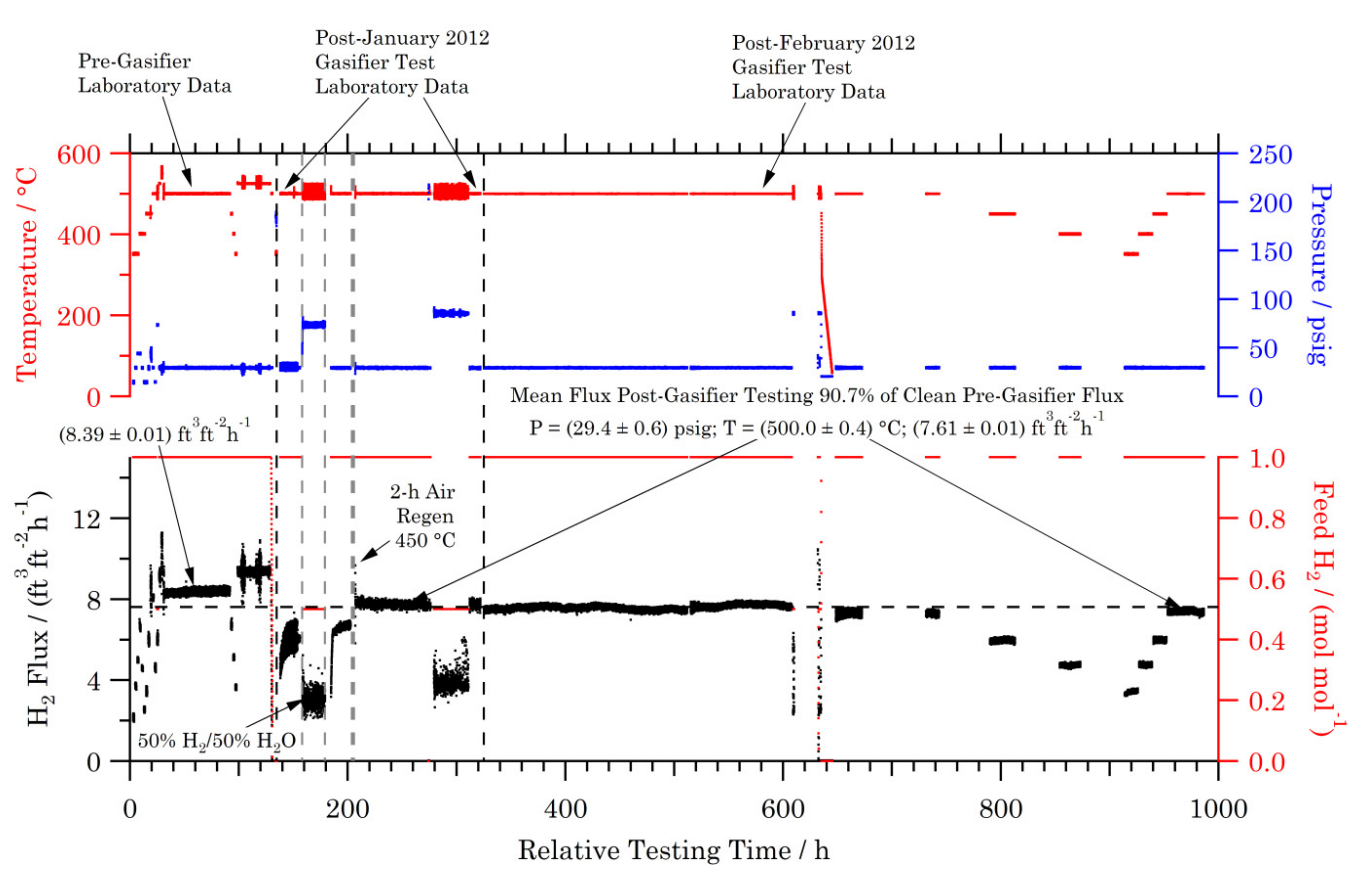

Figure 34: Laboratory testing data for separator 5312 before and after January 2012 and February 2012 gasifier test runs at EERC.

\subsubsection{Dual Gasifier Test of Separators 5307 \& 5312}

In February 2012 , two pilot-scale $\left(\approx 1.5 \mathrm{ft}^{2}\right)$ separators (5307 \& 5312) were shipped to EERC as test articles for a dual membrane gasifier test. The separators were tested in parallel, bringing the longest total exposure to gasifier exhaust during the project up to 189 hours. The test was conducted using the fluid bed gasifier at EERC. Separator 5312 had been tested for 130 hours on the larger-scale TRDU gasifier in January 2012, while separator 5307 had been tested for 77 hours on the fluid bed gasifier system in September 2011.

For the February 2012 test, syngas from the fluid bed gasifier was taken after hot gas filtration and sent to the same membrane test rig used for previous tests, including the TRDU run in January 2012. Steam was mixed with the syngas and the gas mixture was fed through two beds of KATALCOJM ${ }^{\text {TM }}$ K8-11 sour-shift catalyst. After the shift beds, the converted syngas was passed over a bed of RVS-1 regenerable sorbent to remove sulfur and other trace contaminants. The exhaust gas from the sorbent bed was then fed directly to the EERC membrane test skid and split between the two separators.

Figure 35 and Figure 36 show the data testing summaries for separators 5307 and 5312, respectively. In addition to the main operating metrics, including feed sulfur concentration determined by Dräger tube analysis, the plots also show dashes for the maximum allowable $\mathrm{H}_{2} \mathrm{~S}$ concentration that avoids $\mathrm{Pd}_{4} \mathrm{~S}$ formation. These maximum limits are based upon the $\mathrm{H}_{2}$ recovery at the time of the Dräger tube sample, the current operating conditions, and an $\mathrm{H}_{2} \mathrm{~S}$ to $\mathrm{H}_{2}$ limit of $7.29 \times 10^{-4}$ described in Section 3.3.4. Similar to the TRDU gasifier run in January 2012 on separator 5312, both separators experienced short periods, cumulatively less than 1 hour, where the $\mathrm{H}_{2} \mathrm{~S}$ concentration exceeded the $\mathrm{H}_{2} \mathrm{~S} / \mathrm{H}_{2}$ limit, which correlated with breakthroughs from or switchovers between sorbent beds. As in the case of the January 2012 run, laboratory testing at UTRC has shown that more than 300 hours of exposure at sulfiding conditions is required to fail one of the UTRC separators and therefore that these brief exposures were considered tolerable. 
Throughout the testing, gasifier operation was very stable, in contrast with previous gasifier runs. The $\mathrm{H}_{2}$ concentration varied from $(30.6 \pm 0.1) \%$ in the first 32 hours of the run to a low of $(24.7 \pm 0.1) \%$ at the very end of the experiment. However, the sour-shift beds and the RVS-1 sorbent beds in particular, appeared to have been severely impacted by the previous TRDU run in January 2012. The RVS-1 beds had shortening early breakthrough times (e.g., 33 hours followed by 17 hours), suggesting that the sorbents were at the end of their life. This necessitated the full regeneration of the sorbents in the middle of the run from about 55 hours to 84 hours. Unfortunately, this gained only about 13 more hours before sulfur breakthrough. Toward the end of the run, the separators were placed back on $\mathrm{N}_{2}$ purge to install an Actisorb S2, nonregenerable, sorbent bed to complete the week of testing from about 103 hours forward.

Due to the time lost to switching and regenerating sorbent beds, separator 5307 was tested for a total of 58 hours with gasifier exhaust while separator 5308 was tested for a total of 59 hours. However, the long periods of time (up to 30 hours) spent on $\mathrm{N}_{2}$ purge between sorbent bed switchovers further demonstrated the leak tight construction of the separators at $500{ }^{\circ} \mathrm{C}$ and 500 psia. Separator 5307 demonstrated a maximum $\mathrm{H}_{2}$ separation rate of $(1.84 \pm 0.16) \mathrm{lb}$ day $^{-1}$ at the end of the run and Separator 5312 demonstrated the separation of up to $(1.77 \pm 0.14)$ lb day $^{-1}$. At a lower $\mathrm{H}_{2}$ separation rate of $(1.37 \pm 0.18) \mathrm{lb}$ day $^{-1}$, separator 5307 demonstrated a $\mathrm{H}_{2}$ recovery of $(81.4 \pm 7.8) \%$. Under similar conditions, separator 5312 demonstrated the separation of $(1.23 \pm 0.12) \mathrm{lb}^{-1 a y} \mathrm{H}_{2}$ at a recovery of $(71.3 \pm 8.0) \%$. Including the previous gasifier runs in September 2011 and January 2012, the total gasifier exhaust exposure time was increased to 135 hours for separator 5307 and 189 hours for separator 5312.

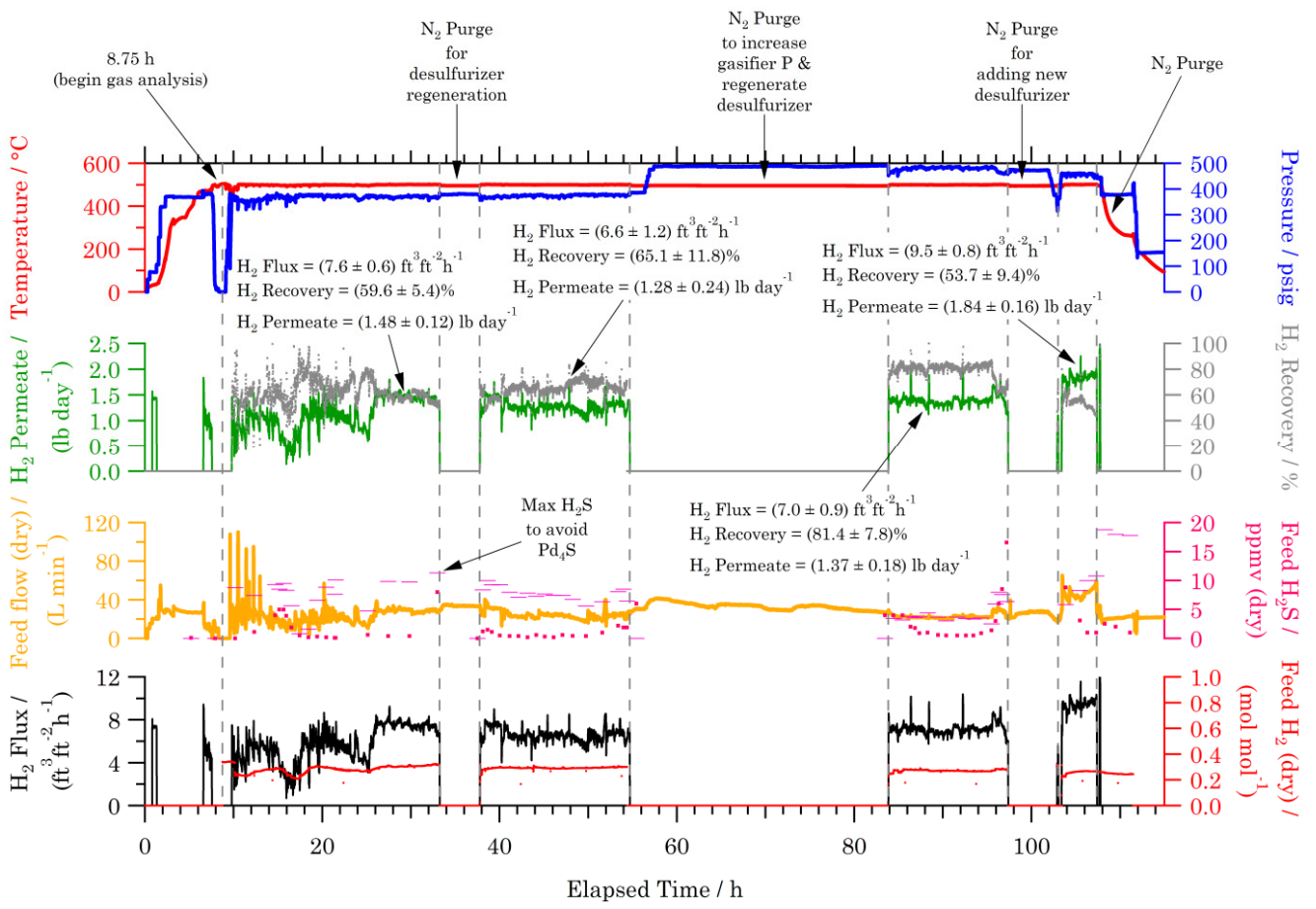

Figure 35: Data summary of coal gasifier test in February 2012 of pilot-scale separator 5307. The separator was tested with gasifier exhaust for a total of 58 hours and separated up to $1.84 \pm 0.16 \mathrm{lb} \mathrm{day}^{-1} \mathrm{H}_{2}$ at $501{ }^{\circ} \mathrm{C}$ and 457 psia. 


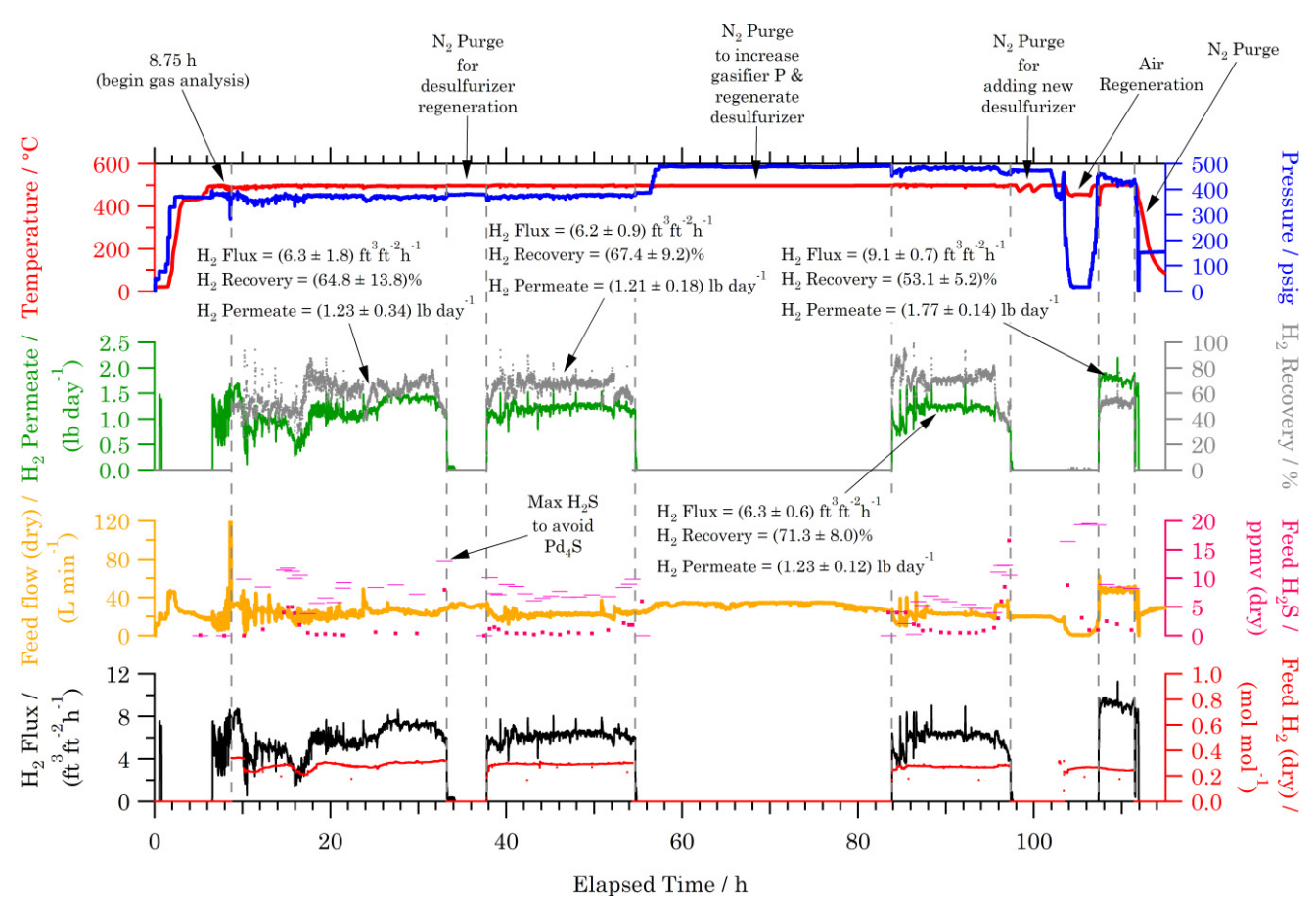

Figure 36: Data summary of coal gasifier test in February 2012 of pilot-scale separator 5312. The separator was tested with gasifier exhaust for a total of 59 hours and separated up to $1.77 \pm 0.14 \mathrm{lb} \mathrm{day}^{-1} \mathrm{H}_{2}$ at $500{ }^{\circ} \mathrm{C}$ and 433 psia.

Real-time first-principles modeling showed that the performance of both separators fluctuated throughout the run after compensating for pressure, flow rate, temperature, and gas composition variations. Figure 37 and Figure 38 show selected data from the gasifier run compared to the model prediction results, shown in blue, for separators 5307 and 5312, respectively. The Figures are divided into various periods, separated by dotted lines, during which the separators' performance changed, or the operating conditions of the test altered (e.g., the separators were switched to $\mathrm{N}_{2}$ purge to switch desulfurization beds). For most of these conditions, the expression $\mathrm{X} \% \mathrm{Q}_{0}$ is used to represent the percent of the ideal pre-exponential factor $\left(\mathrm{Q}_{0}\right)$ for $\mathrm{H}_{2}$ permeability $(\mathrm{Q})$ that was required to make the model agree with the experimental data.

The two separators experienced simultaneous changes in the permeability based on the model, but not necessarily of the same magnitude. In general, the changes in permeability were not as great for separator 5307 as they were for separator 5312. This may have been due to the fact that newer plumbing was installed connecting separator 5307 to the testing rig and also due to differences in the length of plumbing between the sorbent beds and the two separators. 
DE-FE0004967

United Technologies Research Center

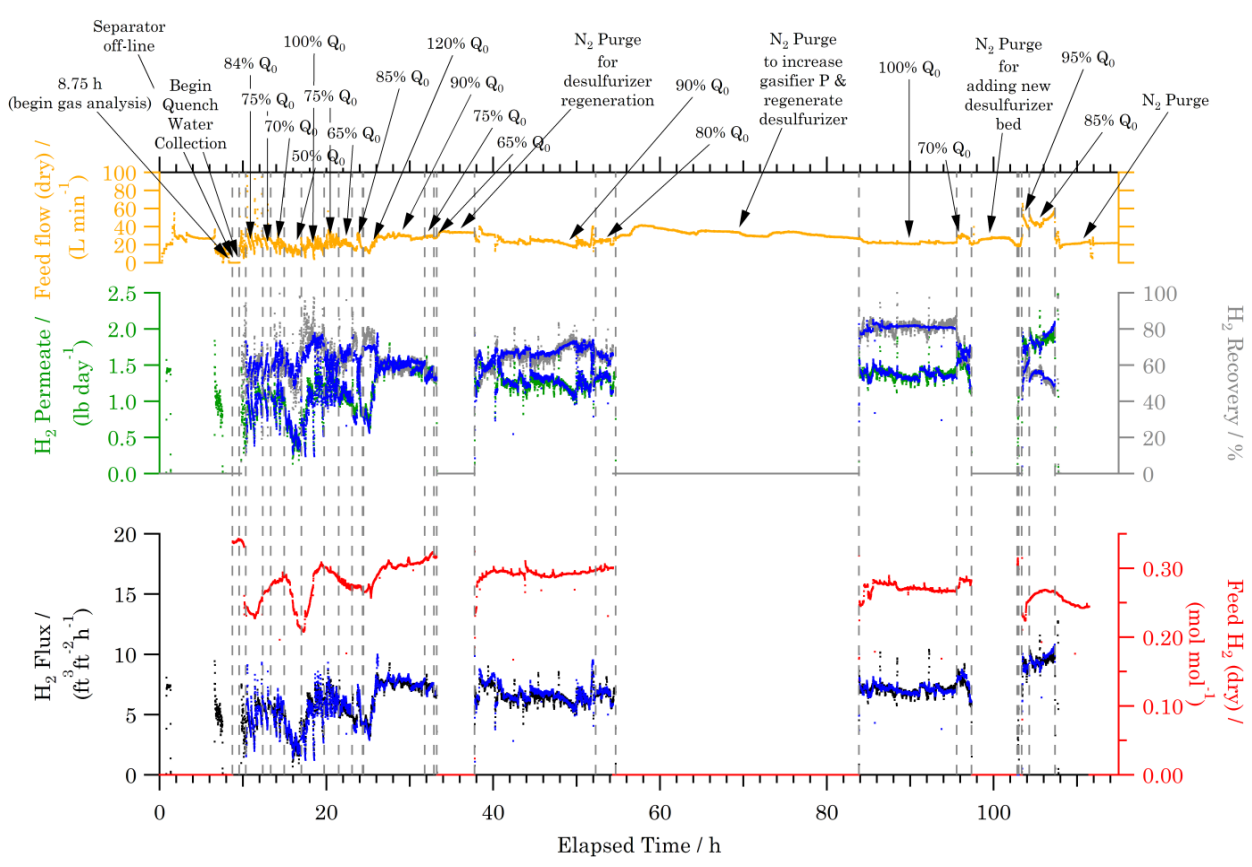

Figure 37: Comparison of data versus model prediction (blue curves) for the coal gasifier test in February 2012 of pilot-scale separator 5307. Real-time first-principles modeling showed that the performance of the separator fluctuated throughout the run; after compensating for pressure, flow rate, temperature, and gas composition variations; dropping as low as $\mathbf{5 0 \%}$.

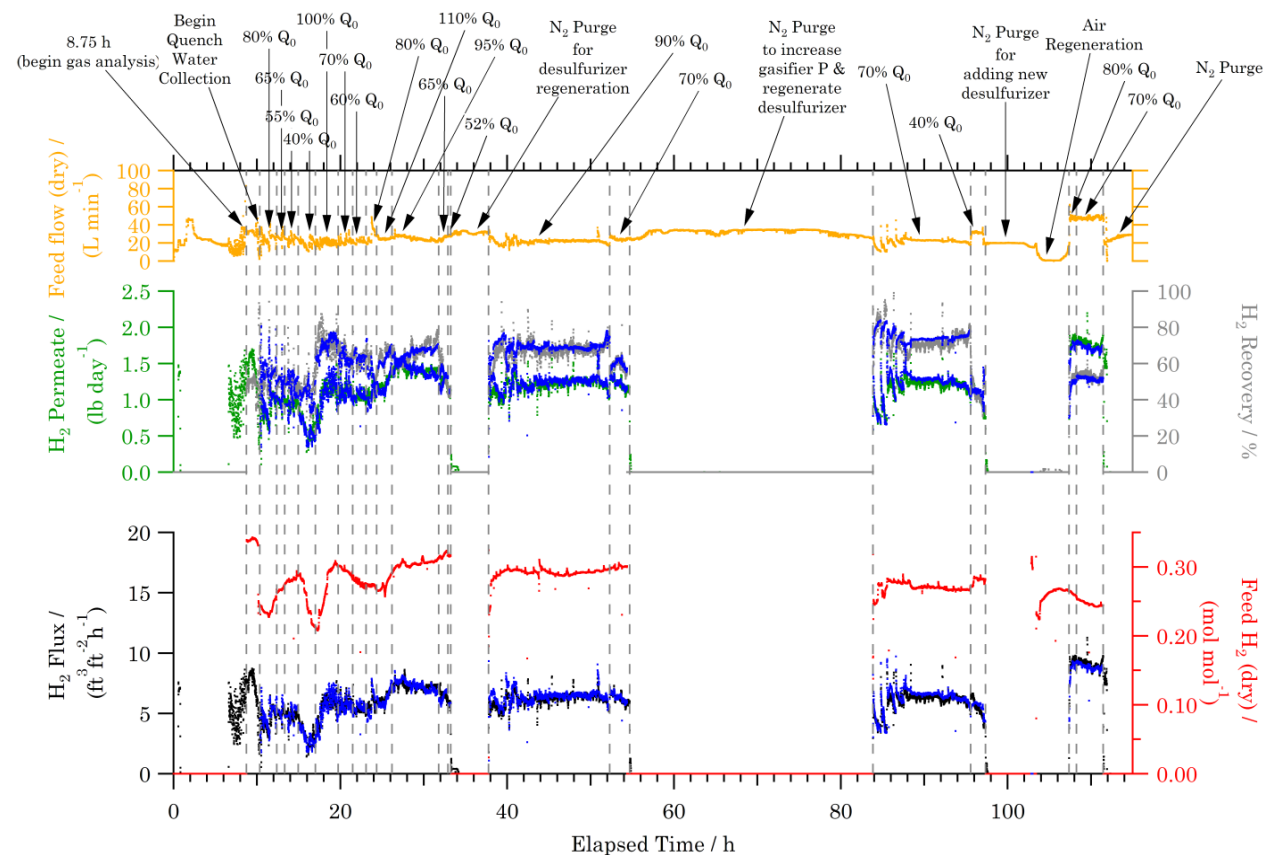

Figure 38: Comparison of data versus model prediction (blue curves) for the coal gasifier test in February 2012 of pilot-scale separator 5312. Real-time first-principles modeling showed that the performance of the separator fluctuated throughout the run; after compensating for pressure, flow rate, temperature, and gas composition variations; dropping as low as $\mathbf{4 0 \%}$. 
Many of the decreases in permeability were partially correlated with the decreasing performance of the RVS- 1 sorbent beds, suggesting that something other than $\mathrm{H}_{2} \mathrm{~S}$ was breaking through the beds and decreasing permeability. Early in the run, separator 5307 suffered a decrease in effective $\mathrm{H}_{2}$ permeability from $84 \% \mathrm{Q}_{0}$ to $50 \% \mathrm{Q}_{0}$ which increased back to $100 \% \mathrm{Q}_{0}$ followed by another monatomic decrease down to $65 \% \mathrm{Q}_{0}$, rising to values between $90 \% \mathrm{Q}_{0}$ and $120 \% \mathrm{Q}_{0}$ before dropping to $65 \% \mathrm{Q}_{0}$ prior to the first sorbent bed sulfur breakthrough at approximately 33 hours (see Figure 37). Separator 5312 underwent permeability changes at essentially the same time periods, but with slightly different values, dropping to $40 \% \mathrm{Q}_{0}$ and $60 \% \mathrm{Q}_{0}$ before rising as high as $110 \% \mathrm{Q}_{0}$ before finally dropping to $52 \% \mathrm{Q}_{0}$ before the sulfur breakthrough.

The periods of $\mathrm{N}_{2}$ purge at temperature and pressure during the switchover or regeneration of the sorbent beds also appeared to help the separators partially recover $\mathrm{H}_{2}$ permeability. For example, the permeability equivalent to $65 \% \mathrm{Q}_{0}$ increased to $90 \% \mathrm{Q}_{0}$ for separator 5307 after the $\mathrm{N}_{2}$ purge following the first sulfur breakthrough. Similarly, separator 5312's permeability increased from $52 \% \mathrm{Q}_{0}$ to $90 \% \mathrm{Q}_{0}$ during the same time period.

The very rapid changes in $\mathrm{H}_{2}$ permeability for the two separators, including periods during which the performance increased, suggested that a reversible poison or blockage was interfering with membrane operation. However, the experimental data accumulated during the project suggested that known potential poisons, such as carbon monoxide and sulfur, would have no effect on separator performance at the concentrations and separator temperatures present during the dual gasifier run. Furthermore, SEM/EDS characterization of separator 5298 after its gasifier test showed no evidence of damage or attack due to the presence of trace metals such as mercury or arsenic.

Additional evidence as to the nature of the reversible poison was provided approximately 52 hours into the gasifier run. Throughout the experiment, control valves downstream of the retentate side of the separators had to be continually adjusted to maintain a constant flow rate. It appeared that the valves were partially blocked by some substance that made it through the separators at $500{ }^{\circ} \mathrm{C}$, but seemed to partially condense farther downstream where it was closer to ambient temperature. At about 52 hours into the run, heat tape was wrapped around these control valves. When the heat tape was turned on, the flow restrictions were immediately removed, resulting in a rapid increase in flow rate through the separators that required adjustment to compensate. As soon as the flow rate increased to the separators, they experienced an immediate decrease in permeability, dropping from $90 \% \mathrm{Q}_{0}$ to $70 \% \mathrm{Q}_{0}$ in the case of separator 5312 . Thus, the poison appeared to be a vapor at the separator temperature of $500{ }^{\circ} \mathrm{C}$, a solid at near ambient temperatures, and a vapor at some intermediate temperature of around $200^{\circ} \mathrm{C}$.

Based on the variable nature of the poison and the information on boiling point and melting point suggested by the valve heat tape results, unconverted tars from the gasifier were suspected. These tars are $\mathrm{C}_{14+}$ high molecular weight, naphthenic, polyaromatic hydrocarbons such as anthracene and phenanthrene. EERC has seen tar build up within the quench pots of the gasifiers in the past, and tars were observed in the quench pots of the fluid bed gasifier which had accumulated between the February 2012 gasifier run as well as three other runs.

During the gasifier run, it was decided to perform an in situ air regeneration on separator 5312 to remove any contaminants. Around 97 hours into the gasifier run, both separators were placed on $\mathrm{N}_{2}$ purge so that an irreversible sorbent, Actisorb S2, could be used for the final phase of the test. After the bed was in place, all of the gasifier exhaust was sent through separator 5307 while separator 5312 underwent an air regeneration. Once the air regeneration was completed, all 
of the flow was diverted to separator 5312 for the remainder of the test. Before the $\mathrm{N}_{2}$ purge and air regeneration, separator 5312's performance had dropped to an effective permeability of $40 \% \mathrm{Q}_{0}$. After the air regeneration, the permeability had increased to $80 \% \mathrm{Q}_{0}$. However, in less than an hour the permeability dropped to $70 \% \mathrm{Q}_{0}$. This data further suggested that the poison causing the reversible separator deactivation was continually being introduced into the separators.

After the dual gasifier run, both separators were tested in the laboratory at UTRC. Figure 32 and Figure 34 show the separator test data post-gasifier testing which indicated that both separators were performing normally. Separator 5307 exhibited an effective $\mathrm{H}_{2}$ flux equivalent to $96.8 \%$ of the as-received, pre-gasifier testing data. Separator 5312 performed at $90.7 \%$ of the asreceived, pre-gasifier testing data, which was identical to the performance prior to the February 2012 gasifier run. Separator 5312 was rinsed and heated in methanol to check for partially soluble tar residue. GC analysis of the methanol wash revealed that trace amounts of high molecular weight hydrocarbons were present in the separator and were most likely polyaromatic hydrocarbons with a carbon number of approximately 18 .

\subsection{Corrosion Testing}

Eight alloys were selected as part of a study on the corrosion of non-membrane materials of construction. The alloys were tested in the laboratory at UTRC for up to 2000 hours at $500{ }^{\circ} \mathrm{C}$ and atmospheric pressure with a gas containing $272 \mathrm{ppmv} \mathrm{H}_{2} \mathrm{~S}$. The alloys were also tested for 2123 hours at the National Carbon Capture Center (NCCC) in Alabama during gasifier operation with temperatures ranging from $387^{\circ} \mathrm{C}$ to $395^{\circ} \mathrm{C}$ and $\mathrm{H}_{2} \mathrm{~S}$ partial pressures between $297 \mathrm{ppmv}$ and 311 ppmv. Gas pressure in the NCCC tests was held between 209 psi and 216 psi. Of the alloys tested, six were chromia formers (SS-316, SS-309, SS-310, C-22, C 276, HR-120) and two were alumina formers (Oak Ridge OC-10, OC-11).

Figure 39 below shows a summary plot of the parabolic weight gain parameter $\left(\mathrm{mg}^{2} \mathrm{~cm}^{-4}\right)$ as a function of exposure time. Down-selection of candidate alloys proceeded by evaluating the alloys in both UTRC laboratory tests and testing downstream of an actual gasifier at NCCC. Optical images of the coupons after 2000 hours of exposure are shown in Figure 40. Table 7 shows the average parabolic weight gain values taken from the triplicate coupons of each material after 2123 hours of exposure in comparison with the laboratory corrosion rate constants after 2000 hours of testing. Note that the rate constants for the NCCC gasifier samples were on average a couple of orders of magnitude lower than those observed in the UTRC laboratory tests. This was likely due to the lower temperature in the NCCC gas stream compared to the laboratory tests being run at UTRC.

Using laboratory kinetics data, alloy cost, and the yield strength of each alloy at $538^{\circ} \mathrm{C}$, a total cost of a large-scale $\left(100 \mathrm{lb}\right.$ day $\left.{ }^{-1} \mathrm{H}_{2}\right)$ separator outer shell was calculated. Wall thicknesses of the shell were determined by assuming a pressure vessel with a $\Delta \mathrm{P}$ of $800 \mathrm{psi}$ and thicknesses were increased to account for metal loss due to oxide scale growth. Parabolic kinetic rate constants were used to project the overall oxide scale thickness for each alloy. Oxide scales after 2000 hours of exposure were also examined using focused ion beam (FIB) and transmission electron microscopy (TEM) and found to be on the same order of magnitude as the predicted scale thicknesses. Figure 41 below shows the total projected oxide thickness for 5 years of exposure for each alloy studied. These projected thicknesses are an important factor in alloy selection as scale spallation can potentially lead to localized blockage and uneven distribution of flow through the separator. 
The overall alloy ratings were calculated by multiplying the projected cost of the $100 \mathrm{lb}^{\mathrm{day}}{ }^{-1}$ $\mathrm{H}_{2}$ outer shell by the projected oxide scale thickness as shown in Table 8 . The alloy with the lowest resulting rating parameter was SS-309 followed by SS-310. However, it was noted that approximately half of the alloys showed susceptibility to pitting and localized corrosion (see Figure 40). SS-309 was one of the alloys that exhibited heavy localized attack after 2000 hours of laboratory testing. As this localized corrosion can potentially lead to accelerated end of life, it was determined that SS-310 would be the best alloy selection for this application as it does not show signs of localized pitting corrosion.

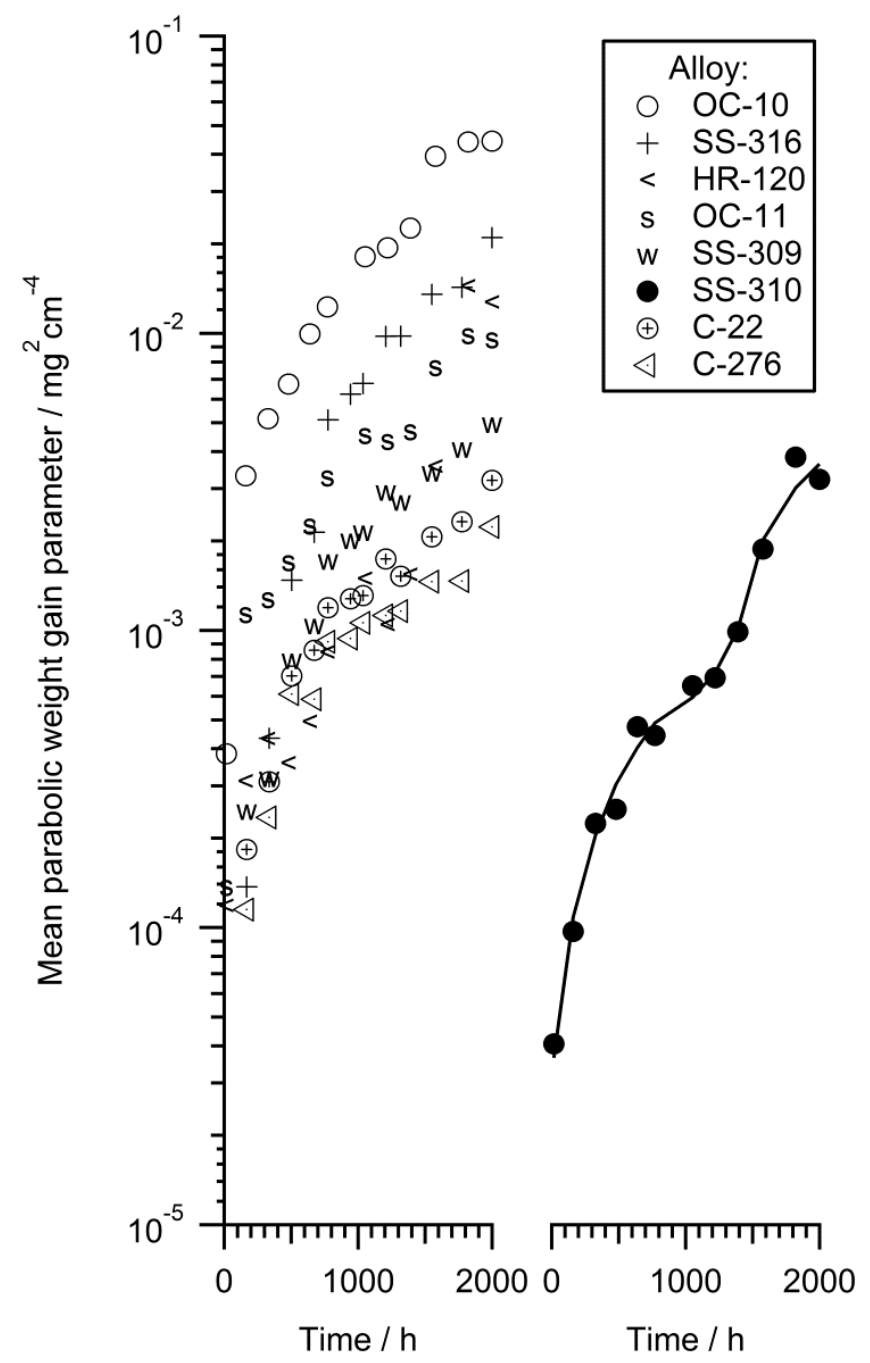

Figure 39: Laboratory corrosion summary of parabolic weight gain versus exposure time for alternative alloys tested at $500{ }^{\circ} \mathrm{C}$ with 272 ppmv $\mathrm{H}_{2} \mathrm{~S}$. 

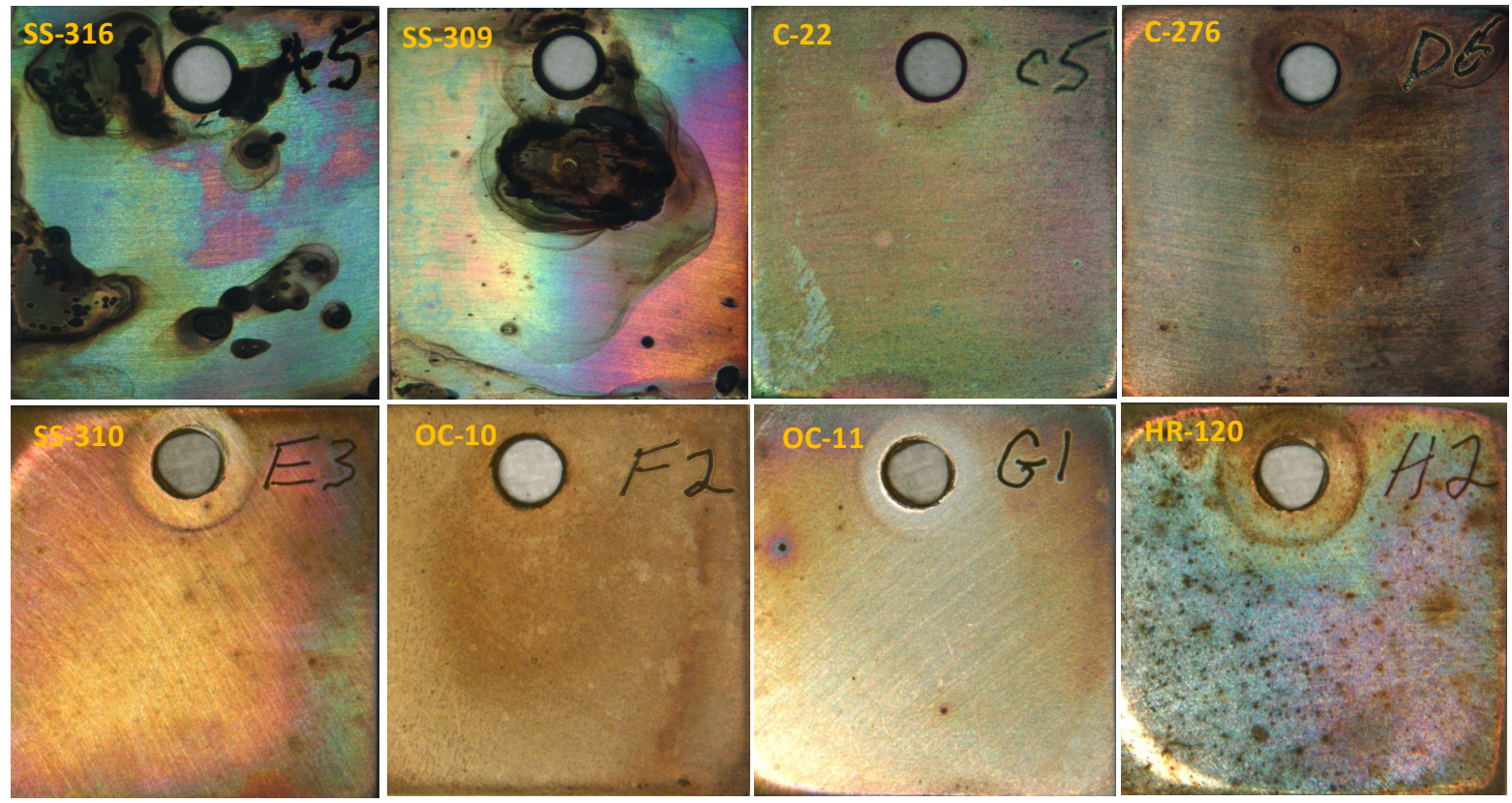

Figure 40: Optical images of alloy coupons after 2000 hours of laboratory exposure. Note that major pitting was observed on SS-316 and SS-309 alloys. The onset of minor pitting was observed on C-276, OC-11 and HR-120 alloys.

Table 7: Parabolic rate constants and relative corrosion resistance rankings for laboratory and NCCC gasifier corrosion tests.

\begin{tabular}{|c|c|c|c|c|c|}
\hline Alloy & $\begin{array}{c}\text { Total Outer Shell Cost for } \\
100 \mathrm{lb} / \text { day Separator }(\$)\end{array}$ & $\begin{array}{c}\text { Projected Scale Thickness } \\
\text { After 5 Years Exposure } \\
(\mu \mathrm{m})\end{array}$ & $\begin{array}{c}\text { Alloy Rating } \\
\text { Parameter }\end{array}$ & $\begin{array}{c}\text { Susceptibility For } \\
\text { Pitting }\end{array}$ & $\begin{array}{c}\text { Overall Alloy Rating } \\
(1=\text { Best, } 8=\text { Worst })\end{array}$ \\
\hline SS-309 & 76.20 & 2.83 & 215.5 & Yes & 1 \\
\hline SS-310 & 99.28 & 2.30 & 228.7 & No & 2 \\
\hline SS-316 & 72.13 & 5.65 & 407.7 & Yes & 3 \\
\hline OC-11 & 139.86 & 3.88 & 543.4 & Yes & 5 \\
\hline C-22 & 334.68 & 2.04 & 683.5 & No & 6 \\
\hline C-276 & 390.08 & 1.75 & 683.8 & No & 7 \\
\hline OC-10 & 92.12 & 8.66 & 797.8 & No & 8 \\
\hline HR-120 & 554.61 & 3.90 & 2162.4 & Yes & \\
\hline
\end{tabular}

Table 8: Overall Alloy Selection Table. While SS-309 has the lowest alloy rating parameter, it showed susceptibility to localized pitting. SS-310 appeared to be the best long-term, costeffective alloy of the eight alloys tested.

\begin{tabular}{|c|c|c|c|c|c|}
\hline Alloy & $\begin{array}{c}\text { Total Outer Shell Cost for } \\
100 \mathrm{lb} / \text { day Separator }(\$)\end{array}$ & $\begin{array}{c}\text { Projected Scale Thickness } \\
\text { After 5 Years Exposure } \\
(\mu \mathrm{m})\end{array}$ & $\begin{array}{c}\text { Alloy Rating } \\
\text { Parameter }\end{array}$ & $\begin{array}{c}\text { Susceptibility For } \\
\text { Pitting }\end{array}$ & $\begin{array}{c}\text { Overall Alloy Rating } \\
(1=\text { Best, } 8=\text { Worst) }\end{array}$ \\
\hline SS-316 & 72.13 & 5.65 & 407.7 & Yes & 3 \\
\hline SS-309 & 76.20 & 2.83 & 215.5 & Yes & 1 \\
\hline SS-310 & 99.28 & 2.30 & 228.7 & No & 2 \\
\hline C-22 & 334.68 & 2.04 & 683.5 & No & 5 \\
\hline C-276 & 390.08 & 1.75 & 683.8 & No & 6 \\
\hline HR-120 & 554.61 & 3.90 & 2162.4 & Yes & 8 \\
\hline OC-10 & 92.12 & 8.66 & 797.8 & No & 7 \\
\hline OC-11 & 139.86 & 3.88 & 543.4 & Yes & 4 \\
\hline
\end{tabular}




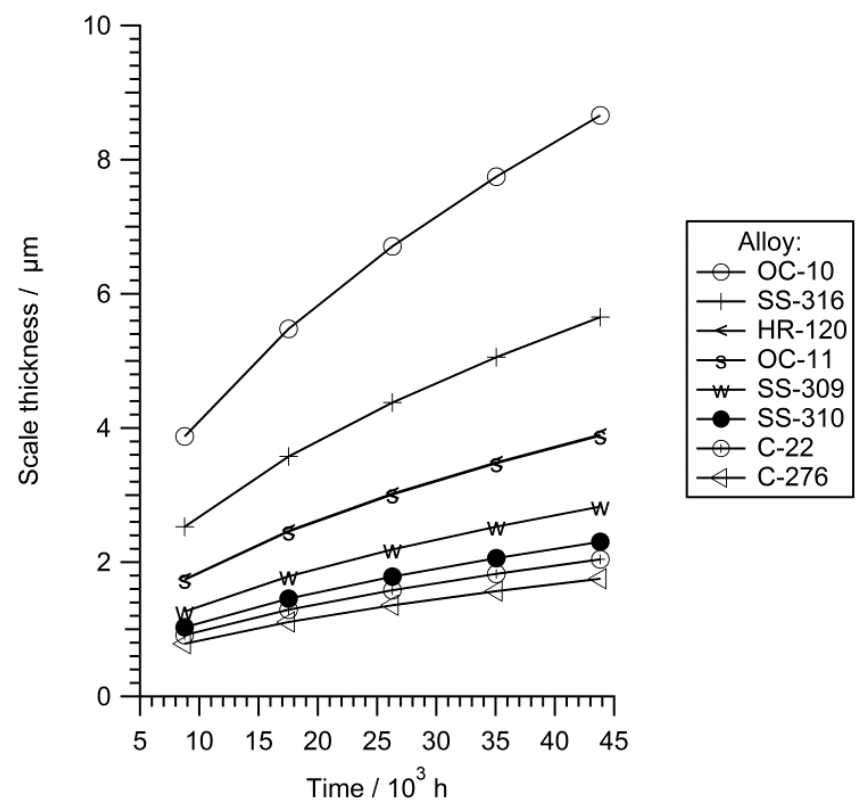

Figure 41: Projected oxide scale thickness versus time were calculated using parabolic rate constants measured in laboratory testing up to 2000 hours of exposure.

\subsection{Engineering Analysis}

An engineering analysis was performed for a larger-scale separator design for a Phase II project based on gasifier test performance data. A $100 \mathrm{lb}_{\text {day }}{ }^{-1} \mathrm{H}_{2}$ module operated at a $\mathrm{H}_{2}$ recovery of $89 \%$ was selected as the appropriate scale for additional scale-up efforts. The $\mathrm{H}_{2}$ separator membrane assembly (HSMA) design has already been commercially manufactured for $\mathrm{H}_{2}$ purifiers and a similar unit was delivered to the U.S. Navy (see Figure 42). The P+E separators have a unique microchannel design which, as UTRC has demonstrated, can eliminate resistances to $\mathrm{H}_{2}$ transport, particularly at high $\mathrm{H}_{2}$ recoveries. $\mathrm{P}+\mathrm{E}$ 's manufacturing processes, combined with the microchannel design, result in very compact, scalable separators with high separation efficiencies. The design also allows for incorporation of improved membrane tubes as they become available in the future. Two $49 \mathrm{ft}^{2}$ separator cells are contained within the $\approx 8 \mathrm{ft}^{3}$ unit. As such, it serves as a repeatable building block unit. Once the HSMA has been validated on real gasifier syngas, significantly fewer steps would be required to construct a larger-scale system. Moving to a 4 ton day $^{-1} \mathrm{H}_{2}$ system would only require connecting multiple units in parallel.
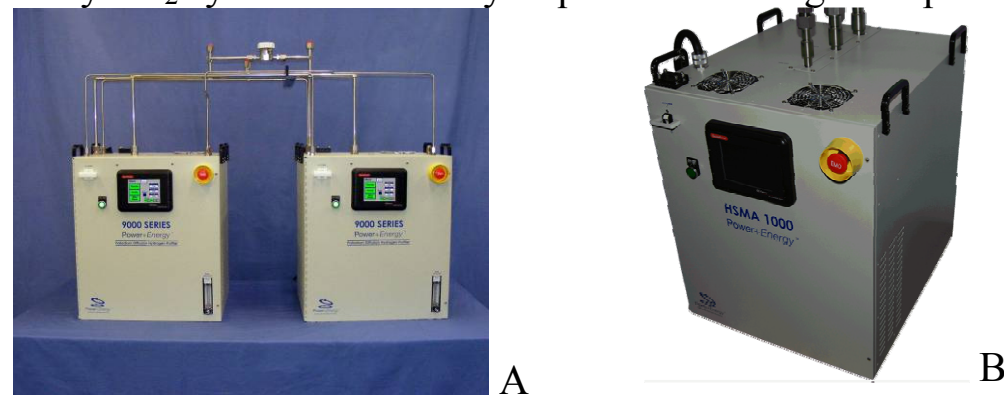

Figure 42: Proposed $100 \mathrm{lb}^{-1} \mathrm{Hay}_{2}$ separator module assembly (HSMA) for scale-up efforts. Image (A) shows two modules plumbed in parallel, each containing approximately $49 \mathrm{ft}^{2}$ of membrane area. The image in (B) is of a similar unit delivered to the U.S. Navy for Logistic Fuel Processing for a fuel cell demonstration. 
Figure 43 shows a plot of the number of Phase II HSMA modules needed for different $\mathrm{H}_{2}$ separation scales assuming the syngas contains $25 \% \mathrm{H}_{2}$ and the modules are operated at $500{ }^{\circ} \mathrm{C}$ and 500 psia. This Figure shows that to achieve the DOE's next phase of scale-up, 4 ton day ${ }^{-1} \mathrm{H}_{2}$, only 83 Phase II units would be required. These could easily be added to larger enclosures, and installed at a large coal gasification plant for evaluation. An additional advantage of using multiple modules versus one large unit for larger scale implementation is to reduce operational risk. A single HSMA failure can be isolated, allowing the rest of the modules to continue operating.

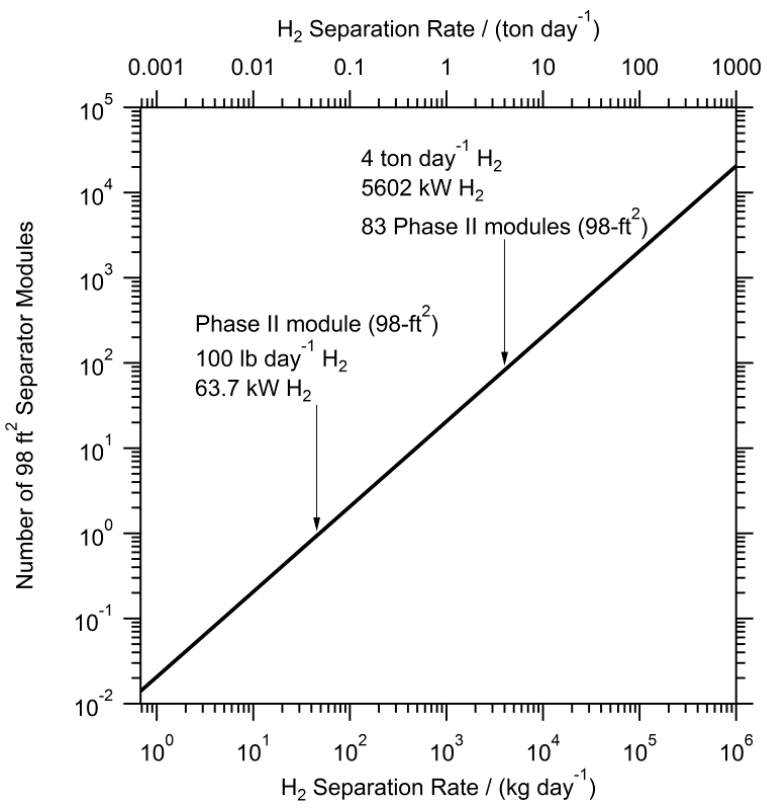

Figure 43: Number of HSMAs depicted in Figure 42A versus $\mathrm{H}_{2}$ separation rate at $89 \%$ recovery for a $25 \% \mathrm{H}_{2}$ syngas at $500{ }^{\circ} \mathrm{C}$ and 500 psia.

The $100 \mathrm{lb} \mathrm{day}^{-1} \mathrm{H}_{2}$ scale would enable the validation of the inlet mixer design for larger separators and further observation of the impact of gas contaminants, such as tars, that cannot be simulated in the laboratory environment. A physics-based model describing membrane performance developed at UTRC was validated during laboratory and gasifier testing at the $\approx 2 \mathrm{lb}_{\text {day }}{ }^{-1} \mathrm{H}_{2}$ scale. The model is based on the assumption that a uniform flow distribution is present at the inlet to all of the membrane tubes. The inlet mixer sections for the two cells in the HSMA have been designed to ensure a well mixed flow to each membrane tube. Thus, deviations in actual performance versus model prediction may indicate a need to further focus efforts on mixer design. However, discrepancies between the model and actual performance may also be due to coal tar and other gas contaminants.

In previous gasifier tests, UTRC used the model to detect reversible changes in separator performance that were not present in laboratory testing but were present in coal gasifier tests of the same separators. This modeling, combined with observations during the gasifier tests, led to further analysis of the separator inside surfaces through methanol washing which suggested that high molecular weight tar-like species such as naphthalenes and phthalates, may be responsible for the changes in performance. Unlike other poisons such as sulfur and $\mathrm{CO}$, laboratory testing cannot be used to effectively substitute for real gasifier testing at high pressure and at larger scale. Testing a $2 \mathrm{lb} d a y^{-1} \mathrm{H}_{2}$ scale separator in parallel with the HSMA should aid in discriminating contaminant and mixing effects using the model. 
The maximum allowable $\mathrm{H}_{2} \mathrm{~S}$ concentration $\left(y_{\text {H2Smax }}\right)$ in the feed gas to prevent irreversible damage to the $\mathrm{Pd}-\mathrm{Cu}$ alloy based on the Phase I data at $500{ }^{\circ} \mathrm{C}$ is represented by Equation (8). For a $\mathrm{H}_{2}$ feed mole fraction $\left(y_{\mathrm{H} 2 \text {, feed }}\right)$ of 0.25 and an overall $\mathrm{H}_{2}$ recovery of $89 \%$, this equation shows that the maximum inlet sulfur concentration should not exceed 2 ppmv to avoid sulfidation failure. This is currently achievable with the warm gas clean up train at EERC. At this level, the $\mathrm{H}_{2} \mathrm{~S}$ concentration will not cause a decrease in separator performance.

$$
y_{\mathrm{H}_{2} \mathrm{~S} \max }=72.9 \times 10^{-6}\left(y_{\mathrm{H}_{2}, \text { feed }}\right)\left(1-\mathrm{H}_{2} \text { Recovery }\right)
$$

Figure 44 shows the engineering analysis model prediction of the HSMA performance given a syngas feed containing $25 \% \mathrm{H}_{2}$. With an inlet feed rate of $1700 \mathrm{~L} \mathrm{~min}^{-1}\left(0{ }^{\circ} \mathrm{C}, 101.325 \mathrm{kPa}\right.$ basis) at 500 psia, the HSMA is predicted to separate more than $100 \mathrm{lb} \mathrm{day}^{-1} \mathrm{H}_{2}$ at a recovery of $89 \%$. As long as the feed $\mathrm{H}_{2} \mathrm{~S}$ concentration is maintained at $\leq 2 \mathrm{ppmv}$, the critical $\mathrm{H}_{2} \mathrm{~S} / \mathrm{H}_{2}$ resulting in irreversible sulfur attack will not be reached. However, operating at a higher $\mathrm{H}_{2}$ recovery will result in very little additional $\mathrm{H}_{2}$ separated with a significantly larger membrane area but subject the separator to the risk of failure within a few hundred hours of operation.
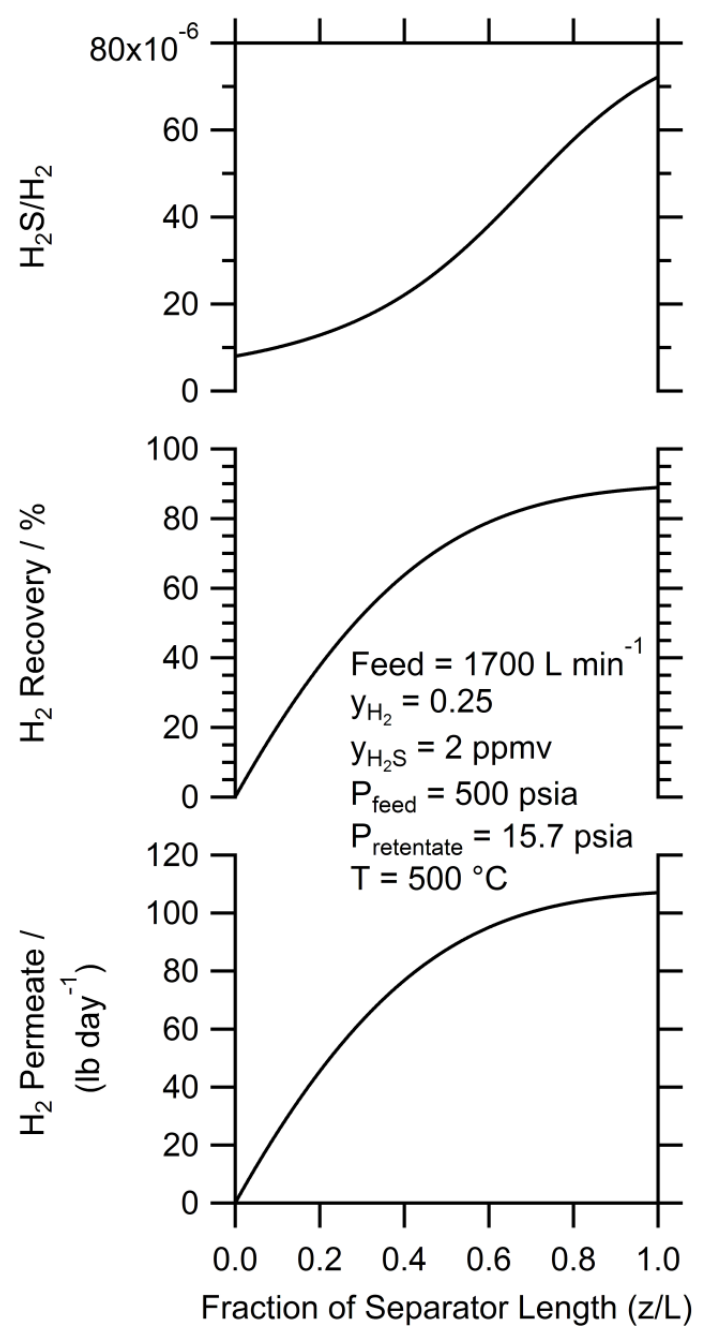

Figure 44: Prediction of HSMA performance for $100 \mathrm{lb}^{-1} \mathrm{H}_{2} \mathrm{H}_{2}$ separation at $89 \% \mathrm{H}_{2}$ recovery. 


\section{Conclusions}

The Phase I data obtained in both laboratory testing and in gasifier tests at EERC have provided the UTRC team with a validated ability to design and predict behavior of $\mathrm{Pd}-\mathrm{Cu}$ membrane separators. Laboratory testing showed that at temperatures greater than $400{ }^{\circ} \mathrm{C}$, typical gas contaminants had no effect on $\mathrm{H}_{2}$ permeability.

The $\mathrm{Pd}-\mathrm{Cu}$ alloy membranes tested in this work showed that $\mathrm{H}_{2}$ permeation from pure $\mathrm{H}_{2}$ at temperatures between $350{ }^{\circ} \mathrm{C}$ and $500{ }^{\circ} \mathrm{C}$ followed Sievert's law. For $\mathrm{H}_{2}$ mixtures with $\mathrm{N}_{2}, \mathrm{CO}$, $\mathrm{CO}_{2}$, or $\mathrm{H}_{2} \mathrm{O}$, no inhibition effects from $\mathrm{N}_{2}, \mathrm{CO}, \mathrm{CO}_{2}$ and $\mathrm{H}_{2} \mathrm{O}$ were observed at temperatures between $400{ }^{\circ} \mathrm{C}$ and $500{ }^{\circ} \mathrm{C}$. As a result, Sievert's law was still valid for the $\mathrm{H}_{2}$ permeation through the $\mathrm{Pd}-\mathrm{Cu}$ separators for $\mathrm{H}_{2}$ gas mixtures, indicating that external mass transfer resistance was insignificant due to the separator design.

The $\mathrm{Pd}-\mathrm{Cu}$ alloy membranes did not show a decline of $\mathrm{H}_{2}$ permeance when 5 ppmv to 39 ppmv $\mathrm{H}_{2} \mathrm{~S}$ was added into the simulated syngas feed at temperatures between $400{ }^{\circ} \mathrm{C}$ and 500 ${ }^{\circ} \mathrm{C}$. This result demonstrated that the $\mathrm{Pd}-\mathrm{Cu}$ membranes tested were sulfur tolerant. The sulfur level in the feed was below the threshold for the formation of thermodynamically stable $\mathrm{Pd}_{4} \mathrm{~S}$. In addition, sulfur inhibition on the $\mathrm{Pd}-\mathrm{Cu}$ membrane surface was not observed at the tested temperature range.

A $\mathrm{N}_{2}$ leak check at 13.79 bar was conducted at the end of the testing of one Pd-Cu separator

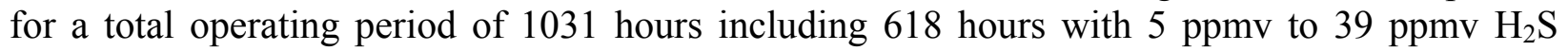
exposure. No leaks were observed. This clearly indicated that the $\mathrm{Pd}-\mathrm{Cu}$ separator tested demonstrated good thermal and structural stability. In addition, an EBSD analysis prior to and post testing showed that no significant particle growth occurred for this type of the $\mathrm{Pd}-\mathrm{Cu}$ membrane in further support of the $\mathrm{N}_{2}$ leak free operation after 1031 hours of testing.

An exception to this is the presence of very high concentrations of $\mathrm{H}_{2} \mathrm{~S}(>39 \mathrm{ppmv})$ and tars coming from a gasifier and not removed by the warm-gas clean up and sour water gas shift treatment. However, based on Equation (8), developed from the information detailed in Section 3.3, there is no practical operating condition (high $\mathrm{H}_{2}$ feed concentration and low $\mathrm{H}_{2}$ recovery or very low $\mathrm{H}_{2}$ feed concentration with very high recovery) where $>39$ ppmv sulfur can be allowed to enter a separator and still avoid irreversible sulfidation. Thus, with properly controlled sulfur levels, no performance degradation will occur due to sulfur in the syngas.

Three different pilot-scale $\left(\approx 1.5 \mathrm{ft}^{2}\right)$ separators were evaluated downstream of coal gasifiers during four different tests and all of the separators demonstrated the targeted separation rate of $2 \mathrm{lb}$ day $^{-1} \mathrm{H}_{2}$. The separator design was proved to be leak tight and durable in the presence of gasifier exhaust contaminants, including sulfur, mercury, and arsenic at temperatures and pressures up to $500{ }^{\circ} \mathrm{C}$ and 500 psia. The Phase I gasifier runs at EERC allowed the performance of the separators to be compared in real-time with the UTRC physics-based model describing membrane performance and showed that the $\mathrm{H}_{2}$ permeability could be repeatedly predicted to within $10 \%$. As a result, the model was used to detect the impact of the gasifier tars that retarded separator performance during the last gasifier run at EERC, which no other group has reported.

In addition to detecting the previously unknown impact of gasifier tars and quantifying the tolerable concentrations of feed $\mathrm{H}_{2} \mathrm{~S}$, the UTRC Phase I effort also focused on determining the best non-membrane materials of construction to ensure separator operation for $\geq 5$ years. Having a membrane that can survive gasifier conditions for years is irrelevant if the non-membrane materials result in a much shorter operating life due to scale growth, resulting in pressure boundary failures or flow obstructions. Eight different alloy candidates, including nickel-based super alloys, chromia-formers, and alumina formers, were exposed to gasifier syngas conditions 
for $>2000$ hours in the laboratory and at the NCCC. That data showed that one of the most common materials of construction, which was also used for the some of the original Phase I separators, stainless steel 316 (SS-316), was highly susceptible to significant weight gain and oxide growth which would severely compromise separator performance. However, several alternative materials, such as stainless steel 310 (SS-310) were identified as suitable substitutes.

Phase I resulted in a validated separator performance model, an understanding of the operating conditions necessary to prevent permanent damage to the membranes, and a knowledge of the desired materials of construction which allowed the prediction of separator performance shown in Section 3.6. This knowledge, combined with the commercial design and fabrication capability of $\mathrm{P}+\mathrm{E}$, could enable the project to move to a larger scale. The key factors that need to be further studied and validated are the impact of gasifier tars and mixer performance on the $100 \mathrm{lb} \mathrm{day}^{-1} \mathrm{H}_{2}$ scale as well as long term effects on materials of construction, such as corrosion and creep. Larger-scale HSMA testing at a suitable gasification facility, such as EERC, combined with additional durability testing and characterization, could be a major milestone toward demonstration of $\mathrm{H}_{2}$ separation modules integrated into advanced co-production facilities by the end of 2016.

\section{References}

[1] Stanislowski, J.J.; Tolbert, S.G.; Curran, T.J.; Swanson, M., Long-Term Demonstration of Hydrogen Production from Coal at Elevated Temperatures, Topical Report. 2012, Energy \& Environmental Research Center, University of North Dakota: Grand Forks, ND.

[2] Emerson, S.C.; Magdefrau, N.J.; Opalka, S.M.; She, Y.; Thibaud-Erkey, C.; Vanderspurt, T.H.; Willigan, R.R., Experimental Demonstration of Advanced Palladium Membrane Separators for Central High Purity Hydrogen Production, DOE Award Number DEFC26-07NT43055 Final Report. 2010, United Technologies Research Center: East Hartford, CT.

[3] Holladay, J.D.; Hu, J.; King, D.L.; Wang, Y., An overview of hydrogen production technologies. Catalysis Today, 2009. 139(4): p. 244-260.

[4] Takht Ravanchi, M.; Kaghazchi, T.; Kargari, A., Application of membrane separation processes in petrochemical industry: a review. Desalination, 2009. 235(1-3): p. 199-244.

[5] Vivanpatarakij, S.; Laosiripojana, N.; Arpornwichanop, A.; Assabumrungrat, S., Performance improvement of solid oxide fuel cell system using palladium membrane reactor with different operation modes. Chemical Engineering Journal, 2009. 146(1): p. 112-119.

[6] Shu, J., Grandjean, B. P. A. , Neste, A. Van, Kaliaguine; , S., Catalytic palladium-based membrane reactors: A review. The Canadian Journal of Chemical Engineering, 1991. 69(5): p. 1036.

[7] Ward, T.L.; Dao, T., Model of hydrogen permeation behavior in palladium membranes. Journal of Membrane Science, 1999. 153(2): p. 211-231.

[8] McKinley, D.L. Metal Alloy for Hydrogen Separation and Purification. US 3350845, November 7, 1967.

[9] McKinley, D.L. Method for Hydrogen Separation and Purification. US 3439474, April 22, 1969. 
[10] Morreale, B.D.; Ciocco, M.V.; Howard, B.H.; Killmeyer, R.P.; Cugini, A.V.; Enick, R.M., Effect of hydrogen-sulfide on the hydrogen permeance of palladium-copper alloys at elevated temperatures. Journal of Membrane Science, 2004. 241(2): p. 219-224.

[11] Opalka, S.M.; Løvvik, O.M.; Emerson, S.C.; She, Y.; Vanderspurt, T.H., Electronic origins for sulfur interactions with palladium alloys for hydrogen-selective membranes. Journal of Membrane Science, 2011. 375(1-2): p. 96-103.

[12] Pomerantz, N.; Ma, Y.H., Novel method for producing high $\mathrm{H}_{2}$ permeability $\mathrm{Pd}$ membranes with a thin layer of the sulfur tolerant $\mathrm{Pd} / \mathrm{Cu} \mathrm{fcc}$ phase. Journal of Membrane Science, 2011. 370(1-2): p. 97-108.

[13] Chen, C.-H.; Ma, Y.H., The effect of H2S on the performance of Pd and Pd/Au composite membrane. Journal of Membrane Science, 2010. 362(1-2): p. 535-544.

[14] Coulter, K.E.; Way, J.D.; Gade, S.K.; Chaudhari, S.; Alptekin, G.O.; DeVoss, S.J.; Paglieri, S.N.; Pledger, B., Sulfur tolerant PdAu and PdAuPt alloy hydrogen separation membranes. Journal of Membrane Science, 2012. 405-406(0): p. 11-19.

[15] Iyoha, O.; Enick, R.; Killmeyer, R.; Morreale, B., The influence of hydrogen sulfide-tohydrogen partial pressure ratio on the sulfidization of $\mathrm{Pd}$ and $70 \mathrm{~mol} \% \mathrm{Pd}-\mathrm{Cu}$ membranes. Journal of Membrane Science, 2007. 305: p. 77-92.

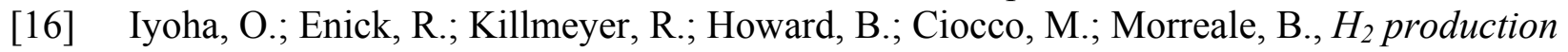
from simulated coal syngas containing $\mathrm{H} 2 \mathrm{~S}$ in multi-tubular Pd and $80 \mathrm{wt} \% \mathrm{Pd}-20 \mathrm{wt} \%$ Cu membrane reactors at 1173 K. Journal of Membrane Science, 2007. 306(1-2): p. 103115.

[17] Kajiwara, M.; Uemiya, S.; Kojima, T., Stability and hydrogen permeation behavior of supported platinum membranes in presence of hydrogen sulfide. International Journal of Hydrogen Energy, 1999. 24(9): p. 839-844.

[18] Barbieri, G.; Scura, F.; Lentini, F.; De Luca, G.; Drioli, E., A novel model equation for the permeation of hydrogen in mixture with carbon monoxide through $P d-A g$ membranes. Separation and Purification Technology, 2008. 61(2): p. 217-224.

[19] Mejdell, A.L.; Jøndahl, M.; Peters, T.A.; Bredesen, R.; Venvik, H.J., Effects of CO and $\mathrm{CO}_{2}$ on hydrogen permeation through a 3 $\mu \mathrm{m} \mathrm{Pd/Ag} 23$ wt.\% membrane employed in a microchannel membrane configuration. Separation and Purification Technology, 2009. 68(2): p. 178-184.

[20] Scura, F.; Barbieri, G.; De Luca, G.; Drioli, E., The influence of the CO inhibition effect on the estimation of the $\mathrm{H} 2$ purification unit surface. International Journal of Hydrogen Energy, 2008. 33(15): p. 4183-4192.

[21] Gielens, F.C.; Knibbeler, R.J.J.; Duysinx, P.F.J.; Tong, H.D.; Vorstman, M.A.G.; Keurentjes, J.T.F., Influence of steam and carbon dioxide on the hydrogen flux through thin Pd/Ag and Pd membranes. Journal of Membrane Science, 2006. 279(1-2): p. 176185.

[22] Hou, K.; Hughes, R., The effect of external mass transfer, competitive adsorption and coking on hydrogen permeation through thin Pd/Ag membranes. Journal of Membrane Science, 2002. 206(1-2): p. 119-130.

[23] Morreale, B.D.; Ciocco, M.V.; Enick, R.M.; Morsi, B.I.; Howard, B.H.; Cugini, A.V.; Rothenberger, K.S., The permeability of hydrogen in bulk palladium at elevated temperatures and pressures. Journal of Membrane Science, 2003. 212(1-2): p. 87-97.

[24] Katsuta, H.; Farraro, R.J.; McLellan, R.B., The diffusivity of Hydrogen in palladium. Acta Metallurgica, 1979. 27(7): p. 1111-1114. 
DE-FE0004967

United Technologies Research Center

[25] Caravella, A.S., Francesco; Barbieri, Giuseppe; and Drioli, Enrico, Inhibition by CO and Polarization in Pd-Based Membranes: A Novel Permeation Reduction Coefficient. J. Phys. Chem. B, 2010. 114: p. 12264-12276.

[26] Augustine, A.S.; Ma, Y.H.; Kazantzis, N.K., High pressure palladium membrane reactor for the high temperature water-gas shift reaction. International Journal of Hydrogen Energy, 2011. 36(9): p. 5350-5360.

[27] Emerson, S.C.; Costello, J.T.; Dardas, Z.; Hale, T.; Hebert, R.R.; Marigliani, G.C.; Opalka, S.M.; She, Y.; Vanderspurt, T.H., Experimental Demonstration of Advanced Palladium Membrane Separators for Central High-Purity Hydrogen Production, in 2008 Annual Merit Review. 2008, U.S. DOE: Arlington, VA.

[28] Emerson, S.C.; Costello, J.T.; Dardas, Z.; Hale, T.; Hebert, R.R.; Marigliani, G.C.; Opalka, S.M.; She, Y.; Vanderspurt, T.H.; Willigan, R.R., Experimental Demonstration of Advanced Palladium Membrane Separators for Central High-Purity Hydrogen Production, in 2009 Annual Merit Review. 2009, U.S. DOE: Arlington, VA.

[29] Caravella, A.; Barbieri, G.; Drioli, E., Concentration polarization analysis in selfsupported Pd-based membranes. Separation and Purification Technology, 2009. 66(3): p. 613-624.

[30] Kulprathipanja, A.; Alptekin, G.O.; Falconer, J.L.; Way, J.D., $P d$ and $P d-C u$ membranes: inhibition of $H 2$ permeation by H2S. Journal of Membrane Science, 2005. 254(1-2): p. 49-62.

[31] Mundschau, M.V.; Xie, X.; Evenson IV, C.R.; Sammells, A.F., Dense inorganic membranes for production of hydrogen from methane and coal with carbon dioxide sequestration. Catalysis Today, 2006. 118(1-2): p. 12-23.

[32] Cleveland, W.S.; Devlin, S.J., Locally Weighted Regression: An Approach to Regression Analysis by Local Fitting Journal of the American Statistical Association, 1988. 83(403): p. 596-610.

[33] Cleveland, W.S.; Devlin, S.J.; Grosse, E., Regression by local fitting: Methods, properties, and computational algorithms. Journal of Econometrics, 1988. 37(1): p. 87114. 